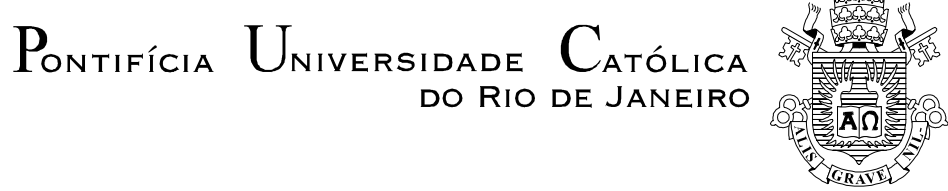

Lilian Vilela Borges de Miranda

Aplicação de um Modelo do Custo para Servir em uma empresa de petróleo

Dissertação de Mestrado (Opção profissional)

Dissertação apresentada como requisito parcial para obtenção do título de Mestre pelo Programa de PósGraduação em Engenharia de Produção da PUCRio.

Orientador: Prof. Luiz Felipe Roris Rodriguez Scvarda do Carmo Co-Orientador: Marcelo Maciel Monteiro 


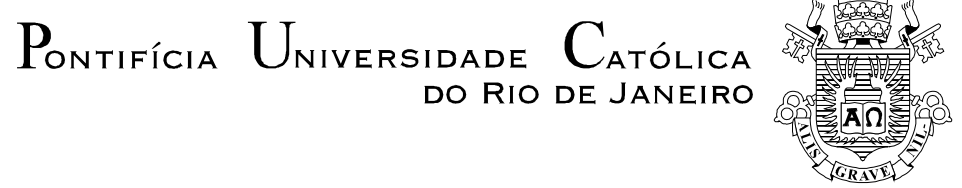

Lilian Vilela Borges de Miranda

\title{
Aplicação de um Modelo do Custo para Servir em uma empresa de petróleo
}

Dissertação apresentada como requisito parcial para obtenção do título de Mestre pelo Programa de PósGraduação em Engenharia de Produção da PUC-Rio. Aprovada pela Comissão Examinadora abaixo assinada.

\section{Prof. Luiz Felipe Roris Rodriguez Scvarda do Carmo Orientador Departamento de Engenharia Industrial - PUC-Rio \\ Marcelo Maciel Monteiro \\ Co-Orientador \\ Petróleo Brasileiro S.A. \\ Prof. Nélio Domingues Pizzolato Departamento de Engenharia Industrial - PUC-Rio}

\author{
Prof. José Eugênio Leal \\ Departamento de Engenharia Industrial - PUC-Rio \\ Prof. José Eugênio Leal \\ Coordenador Setorial do Centro \\ Técnico Científico - PUC-Rio
}


Todos os direitos reservados. É proibida a reprodução total ou parcial do trabalho sem autorização da universidade, do autor e do orientador.

\section{Lilian Vilela Borges de Miranda}

Graduou-se em Engenharia de Produção na Pontifícia Universidade Católica do Rio de Janeiro em 2003. Cursou Logística Empresarial na COPPEAD/UFRJ. Estágio na área de Transporte e Logística nas Sendas e na área de Planejamento e Controle da Produção na Farmoquímica. Atuou como Trainee e Coordenadora de Produção na Gerdau. Atualmente trabalha na área de Logística do Abastecimento da Petróleo Brasileiro S.A.

Ficha Catalográfica

Vilela Borges de Miranda, Lilian

Aplicação de um Modelo do Custo para Servir em uma empresa de petróleo / Lilian Vilela Borges de Miranda; orientador: Luiz Felipe Roris Rodriguez Scvarda do Carmo; co-orientrador: Marcelo Maciel Monteiro - 2013.

94 f.: il. (color.) ; $30 \mathrm{~cm}$

Dissertação (mestrado) - Pontifícia Universidade Católica do Rio de Janeiro, Departamento de Engenharia Industrial, 2013.

Inclui bibliografia

1. Custo para Servir. 2. Cadeia de Suprimento. 3. Análise de Custo. 4. Logística. 5. Indicadores de Desempenho. 6. Indústria de Petróleo e Gás. 7. Custeio ABC I. Scavarda, Luiz Felipe. II. Monteiro, Marcelo Maciel. III. Pontifícia Universidade Católica do Rio de Janeiro. Departamento de Engenharia Industrial. III. Título. 


\section{Agradecimentos}

A Deus, por me ter me dado saúde, uma família maravilhosa, por ter colocado meu marido na minha vida e ter me dado grandes amigos. Aos meus pais, que cultivaram em mim um sentimento de busca de crescimento pessoal, intelectual e profissional, sempre me apoiando nesse sentido. Aos meus irmãos e suas famílias, que só pelo fato de existirem e serem presentes na minha vida, me deram forças para continuar o caminho trilhado. Ao meu marido, por ser meu maior companheiro, por ser compreensivo e incentivador nos momentos difíceis. Por me ensinar, pelo próprio exemplo, a ser mais tranquila e paciente na busca dos resultados esperados.

Ao meu ex-Gerente Geral, Carlos Felipe Guimarães Lodi pelo incentivo e reconhecimento , ao meu ex-gerente Abdias Fernandez Ramos pela indicação para o curso de mestrado e meu atual gerente João Fernando Monteiro Campos pelas orientações técnicas, valorização e respeito ao meu trabalho. Aos meus colegas de trabalho da Petróleo Brasileiro S.A, da gerência de Avaliação Operacional, que por muitas vezes me auxiliaram na construção dos conceitos e por me substituírem nos momentos de ausência em função da dedicação ao trabalho.

Aos meus colegas do curso de Mestrado, pelo excelente convívio nas aulas, por agregarem conhecimento nos trabalhos durante o curso e por compartilharam suas experiências na elaboração do projeto final.

Ao meu co-orientador, Marcelo Maciel Monteiro, pela sua paciência e dedicação.

Aos professores da comissão examinadora, pela sua disponibilidade e contribuição no conteúdo final do trabalho.

Agradeço a Petróleo Brasileiro S.A. por ter patrocinado o curso e à Pontifícia Universidade Católica do Rio de Janeiro, nas pessoas do meu orientador e mestres. 


\section{Resumo}

Miranda, Lilian Vilela Borges. Luiz Felipe Roris Rodriguez Scvarda do Carmo. Aplicação de um Modelo do Custo para Servir em uma empresa de petróleo. Rio de Janeiro, 2013. 94p. Dissertação de Mestrado (Opção profissional) - Departamento de Engenharia Industrial, Pontifícia Universidade Católica do Rio de Janeiro.

Atualmente, todas as frentes de mercado estão altamente competitivas, o que remete a necessidade das empresas se adequarem a esta competição, otimizando seus processos, visando principalmente à redução dos seus custos. Historicamente, a gestão de custos de uma companhia sempre teve um foco contábil, principalmente para o atendimento dos requisitos fiscais e tributários. O ponto é que este tipo de visão de custos não permitia e, ainda não permite uma atuação gerencial na melhoria dos processos e nem suporta adequadamente decisões operacionais, visto que agrega as informações operacionais e aloca os custos indiretos de forma aleatória. Com a necessidade de aprimoramento da gestão de custos, surgem então novas formas de alocação de custos, das quais será enfatizado o modelo de Custeio ABC (Activity Based Cost), que se propõe alocar os custos indiretos por atividade. Decorrente deste modelo, pode-se verificar a rentabilidade dos clientes através do Custo para Servir, onde após a alocação de custos pelas atividades, faz-se o direcionamento destes custos aos objetos de análise, que neste caso seria o cliente. Com isso, o presente trabalho vem propor a implementação de um modelo para medição do Custo para Servir na Cadeia Logística da Petrobras, a principal empresa de petróleo brasileira, que é considerada uma das dez maiores empresas do mundo. Assim como na maioria das empresas, a prática de gestão de custos na Petrobras não permite, por exemplo, o gestor ter uma visão operacional das falhas dos processos, assim como quais os clientes mais rentáveis ou as rotas mais dispendiosas. Alguns indicadores de custo são acompanhados, mas estes não viabilizam tais tipos de análise. Sendo assim, foram definidas as métricas de medição dos custos e seus respectivos 
direcionadores, bem como a modelagem de uma ferramenta de análise para a medição do Custo para Servir. Algumas simplificações foram estabelecidas em função da viabilização da implantação e pontos levantados sobre a utilização de ferramenta existente no mercado e a elaboração, pela própria empresa, de uma solução completamente customizada. O trabalho é finalizado com algumas sugestões para a implementação da ferramenta, assim como sugestões de aprofundamento e desdobramento do assunto.

\section{Palavras-chave}

Custo para Servir; Cadeia de Suprimento; Análise de Custo; Logística; Indicadores de Desempenho; Indústria de Petróleo e Gás; Custeio ABC. 


\section{Abstract}

Miranda, Lilian Vilela Borges. Luiz Felipe Roris Rodriguez Scvarda do Carmo (Advisor). Applying a Cost to Serve model in a Petroleum company. Rio de Janeiro, 2013. 94p. MSc. Dissertation (Professional option) - Departamento de Engenharia Industrial, Pontifícia Universidade Católica do Rio de Janeiro.

Currently, there is a highly competitive market, which suggests that companies need to conform to this competition by optimizing their processes, principally aimed at reducing their costs. Historically, the cost management of a company has always had an accounting focus, primarily for tax compliance and tax requirements. But, this kind of costs visualization does not offer facilities to the manager act in process improvement nor supports operational decisions, whereas aggregates operational information and allocates indirect costs randomly. As the improvement of management costs becomes necessary, new methodologies of cost allocation appeared, from which the $\mathrm{ABC}$ (Activity Based Costing) Method, which proposes to allocate indirect costs by activity, will be emphasized in this work. Resulting from this method, we can check the profitability of customers through the Cost to Serve, that after the allocation of costs by activities, it is linked to the object of analysis, which, in this case, would be the client. Thus, this work proposes the implementation of a model for measuring the Cost to Serve in the supply chain of Petrobras, a Brazilian oil company that is considered one of the ten largest companies in the world. As in most part of the companies, the practice of cost management at Petrobras does not allow, for example, managers to have an overview of the operational failures of processes, as well as which customers are more profitable or which are the more costly routes. Some cost indicators are monitored, but these do not enable these types of analysis. Thereat, it was defined metrics for measuring the costs, as well as modeled an analysis tool to measure the Cost to Serve. Some simplifications were established to become 
viable the implementation and some points were presented about using an existing tool for the model and the development, by the company itself, of a completely customized solution. The work ends with some suggestions for the implementation of the tool as well as suggestions for further development and deployment around the subject.

\section{Keywords}

Cost to Serve; Supply Chain; Costs Analysis; Logistics; Performance Indicators; Oil and Gas Industry; ABC Method. 


\section{Sumário}

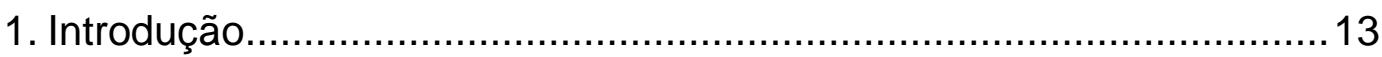

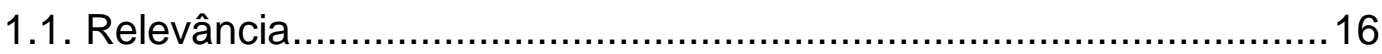

1.2. Objetivos e Delimitação do Trabalho............................................. 17

1.3. Estrutura do Trabalho............................................................... 18

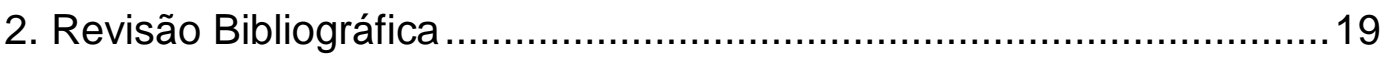

2.1. Cadeia de Suprimento e Logística ................................................ 19

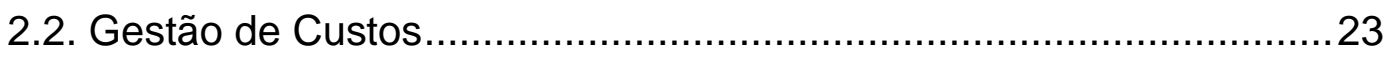

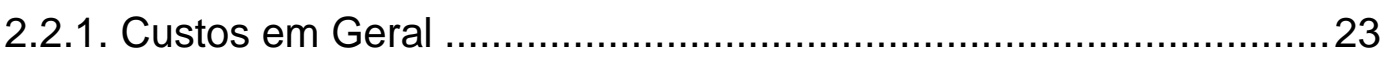

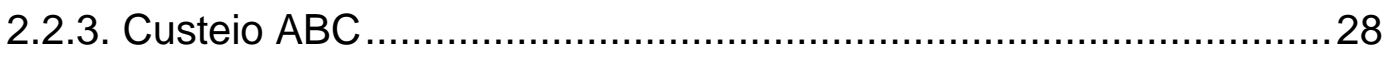

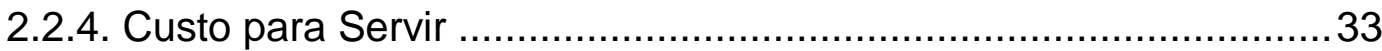

2.3. Indicadores de Desempenho na Logística ......................................38

3. Petrobras e Gestão de Custos ............................................................. 40

4. Conceituação da Metodologia do Modelo do Custo para Servir e etapas

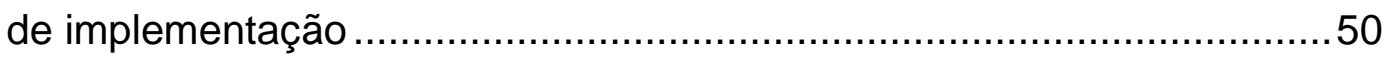

4.1. Conceitos da Petrobras e de Análise de Custos ..............................52

4.2. Levantamento das Atividades Envolvidas na Logística do

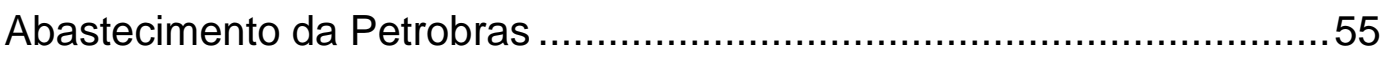

4.3. Levantamento dos Direcionadores de Custo das Atividades Envolvidas na Área de Logística do Abastecimento da Petrobras ............57

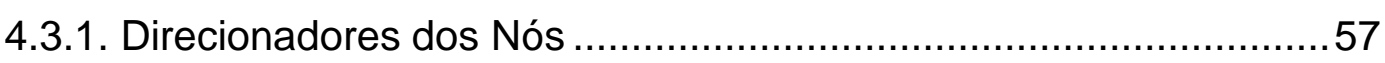

4.3.2. Direcionadores dos Arcos ou Movimentação .................................59

4.4. Levantamento dos Objetos de Análise do Custo para Servir .............60 
5. Aplicação da Modelagem de Custos na Logística do Abastecimento da Petrobras. 62

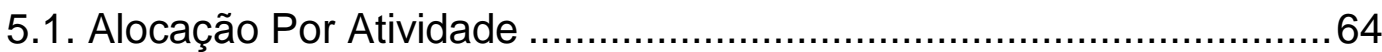

5.2. Visualização dos Custos por Atividade Numa Ferramenta de

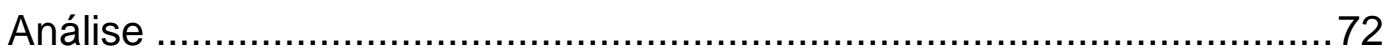

5.3. Carregamento de Dados para obtenção do Custo para Servir...........76 5.4. Visualização do Custo da Cadeia Integrada Numa Ferramenta de

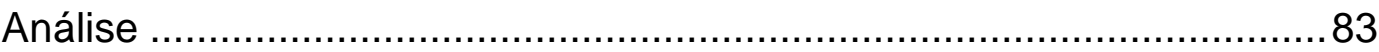

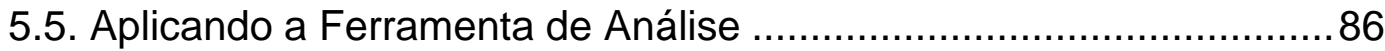

6. Considerações Finais, Conclusão e Recomendações …………...........89

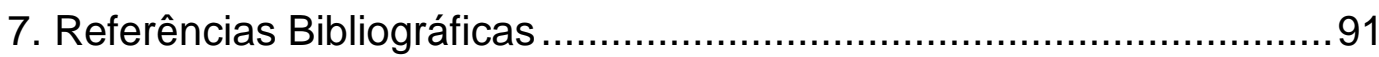




\section{Lista de Figuras}

Figura 01 - Custos Logísticos frente ao PIB Brasil ............................... 15

Figura 02 - Percentual dos Custos Logísticos no Valor Agregado .......... 15

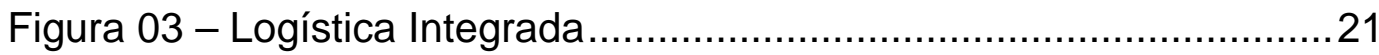

Figura 04 - Esquema ilustrativo do Custeio por Absorção.........................2 29

Figura 05 - Esquema ilustrativo da Alocação de Custos no

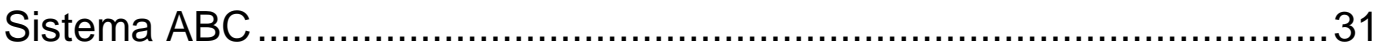

Figura 06 - Administração de clientes com base no custo do cliente

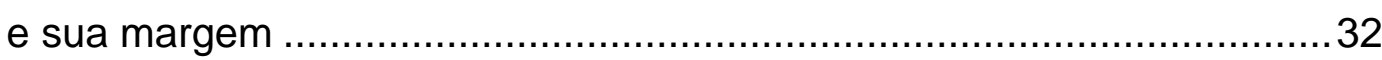

Figura 07 - Ações de acordo com Volume e Custo de Atendimento ........36

Figura 08 - Trocas compensatórias entre Marketing e Logística..............38

Figura 09 - Percentual de utilização de fonte de energia ......................... 40

Figura 10 - Percentual de utilização de fonte de energia - Brasil............. 41

Figura 11 - Histórico de utilização de fonte de energia - Brasil................ 42

Figura 12 - Logística Integrada na Petrobras ...................................... 43

Figura 13 - Custos da Logística / Custos do Dowstream (em percentual)

Figura 14 - Custos de Transporte Marítimo / Custo da Logística (em

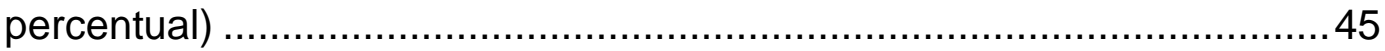

Figura 15 - Estratificação dos Custos de Transporte Marítimo................. 45

Figura 16 - llustração de Gráfico Cachoeira - visualização da margem de bolso através do Custo para Servir ................................................ 51

Figura 17 - Esquema simplificado da Cadeia Integrada da Petrobras.....54

Figura 18 - Hierarquia dos Elementos de Custos por buckets..................62

Figura 19 - Exemplo de exibição dos Buckets de custos .........................75

Figura 20 - Exemplo de Detalhamento dos Buckets...............................76

Figura 21 - Esquema simplificado da Cadeia Integrada da Petrobras.....77

Figura 22 - Exemplo de exibição dos Buckets de custos da Cadeia Integrada .85

Figura 23 - Exemplo de Detalhamento dos Buckets para um determinado Bucket 


\section{Lista de tabelas}

Tabela 01 - Métricas de Análise de Custos .........................................27

Tabela 02 - Modelo de Quatro Estágios para projetar um sistema de

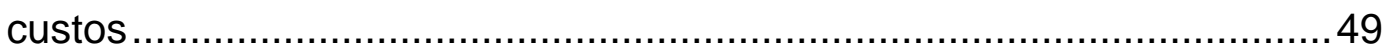

Tabela 03 - Dados de Custos do Local 1 (Origem) .................................79

Tabela 04 - Dados de Custos da Movimentação....................................... 79

Tabela 05 - Dados de Custos da Viagem 1 (origem - destino 1) .............79

Tabela 06 - Dados de Custos da Viagem 2 (origem - destino 2) ............. 80

Tabela 07 - Dados de Custos do Destino 1 ........................................... 81

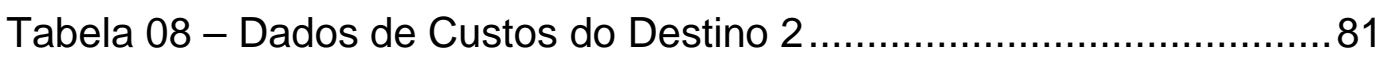

Tabela 09 - Dados de Custos Calculados da Viagem 2 .......................... 81

Tabela 10 - Dados de Custos Arco a Arco (exemplo prático).................... 82

Tabela 11 - Classificação por nível nos Custos da Cadeia Integrada ......83

Tabela 12 - Classificação por nível nos Custos da Cadeia Integrada

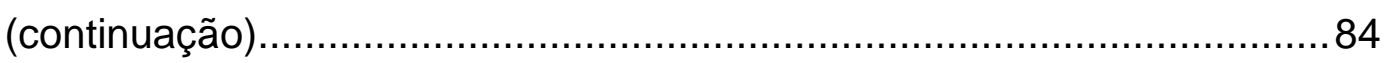




\section{1 \\ Introdução}

A globalização, a rápida evolução tecnológica, as facilidades de comunicação e acesso, estão tornando os mercados altamente competitivos. No ambiente de negócios, os clientes estão cada vez mais exigentes e há uma procura incessante pela eficiência dos processos objetivando atender a estes altos níveis de serviço.

Uma medida para se aumentar a competitividade e a lucratividade das empresas, segundo Gunasekaran et al. (2001) é fazer a Gestão da Cadeia de Suprimento. Ballou (2006) afirma que gerenciar a Cadeia de Suprimento significa integrar seus processos, buscando um resultado melhor para o todo. Os processos desta cadeia são as operações compreendidas entre a extração da matéria prima e a entrega do produto ao consumidor final, englobando inclusive seus fluxos de informação.

Níveis de serviços elevados levam instantaneamente ao aumento de custos das operações de uma empresa, pois requerem maior flexibilidade e agilidade nas respostas às demandas dos clientes, que, por seus lados, não querem pagar mais por isso. Em função de manter seus negócios lucrativos, as empresas se veem obrigadas a reduzir seu custo, mas para isso precisam conhecê-los melhor.

Uma forma de Gerenciar os Custos é através das informações contábeis existentes nas empresas, que, tradicionalmente alocam custos indiretos aleatoriamente e calculam os custos dos produtos. No Brasil, pela Legislação (Lei 6.404), as empresas são obrigadas a ter uma Contabilidade Financeira, que é a vertente da contabilidade onde são apresentadas as demonstrações contábeis, procurando explanar a situação financeira da empresa (BRASIL, 1976). Este tipo de contabilidade dificilmente auxilia os gestores nas tomadas de decisão estratégicas no que diz respeito às operações, já que contabiliza de forma agregada os custos associados a estas operações. 
A Contabilidade Financeira por sua vez, não explicita claramente os custos envolvidos em cada uma destas atividades. Faria e Costa (2005) afirmam que a Demonstração de Resultados elaborada pela área de Contabilidade de uma empresa não mostra, por exemplo, o Custo Logístico Total, podendo suas parcelas estar presentes em contas diferentes da Demonstração.

Isto foi mencionado anteriormente por Johnson e Kaplan (1991), que até os dias de hoje, a forma atual de Contabilidade de Custos nas empresas se mantém a mesma, não atendendo aos requisitos dos gestores de Logística no auxílio à tomada de decisões, pois não identificam claramente o comportamento dos processos e das atividades.

Christopher (1997) corrobora, dizendo que é preciso apurar os custos logísticos para atender aos níveis de serviço requeridos numa Logística Integrada e que os métodos tradicionais de contabilidade não auxiliam neste processo.

A logística, de acordo com Goebel (1996), engloba as atividades de movimentação e armazenagem desde a obtenção da matéria prima até a entrega no consumidor final, atendendo aos níveis de serviços adequados aos clientes e a um custo razoável. Segundo Quinn (2001), estes custos podem chegar a 30\% dos custos totais de uma empresa. Trinta por cento dos custos totais de uma empresa é um percentual bem representativo, que deve ser priorizado num momento de redução de custos, por exemplo, visando aumentar a competitividade de uma empresa.

Maurício Lima (2006) mostra que no Brasil de 2004, estes custos logísticos representaram cerca de $12,60 \%$ do PIB (Produto Interno Bruto) nacional. Este percentual foi estratificado conforme Figura 01, que mostra que a principal parcela foi a de transporte.

De acordo com Jeffery et al. (2008), custo logístico total deve ser o menor que se possa incorrer na operação de entrega visando atender o foco da logística integrada que é disponibilizar produtos de qualidade, no prazo e quantidades acordadas, objetivando proporcionar o nível de serviço oferecido ou contratado. Qualquer exigência ou serviço ofertado para o cliente tem um custo associado. Por isso, é importante que estes custos estejam claros para a empresa, segundo Kaplan e Cooper (2000). 


\section{\% PIB}

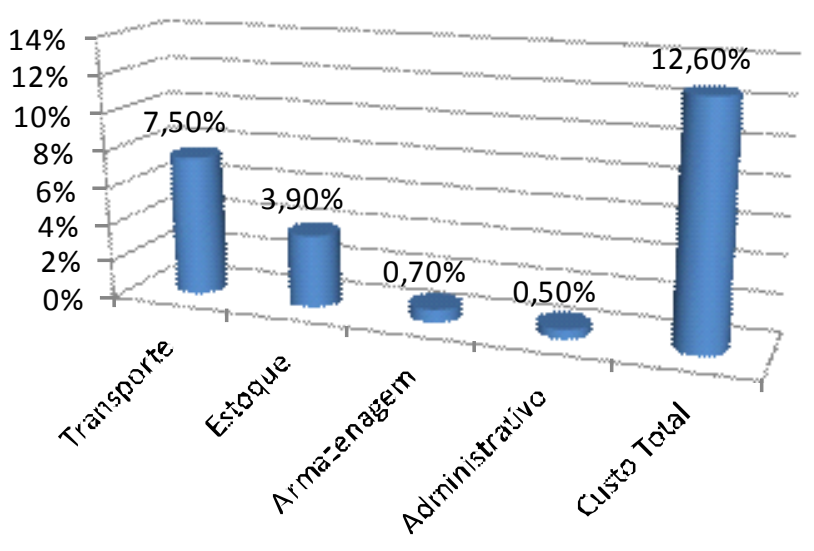

Figura 01 - Custos Logísticos frente ao PIB Brasil Fonte: Adaptado de Maurício Lima (2006).

Lambert, Stock e Vantine (1998) mostra que a indústria do petróleo quando relacionada a outros segmentos, possui a maior relação entre os custos logísticos e o valor agregado, conforme apresentado na Figura 02.

\section{$\%$ Valor Agregado}

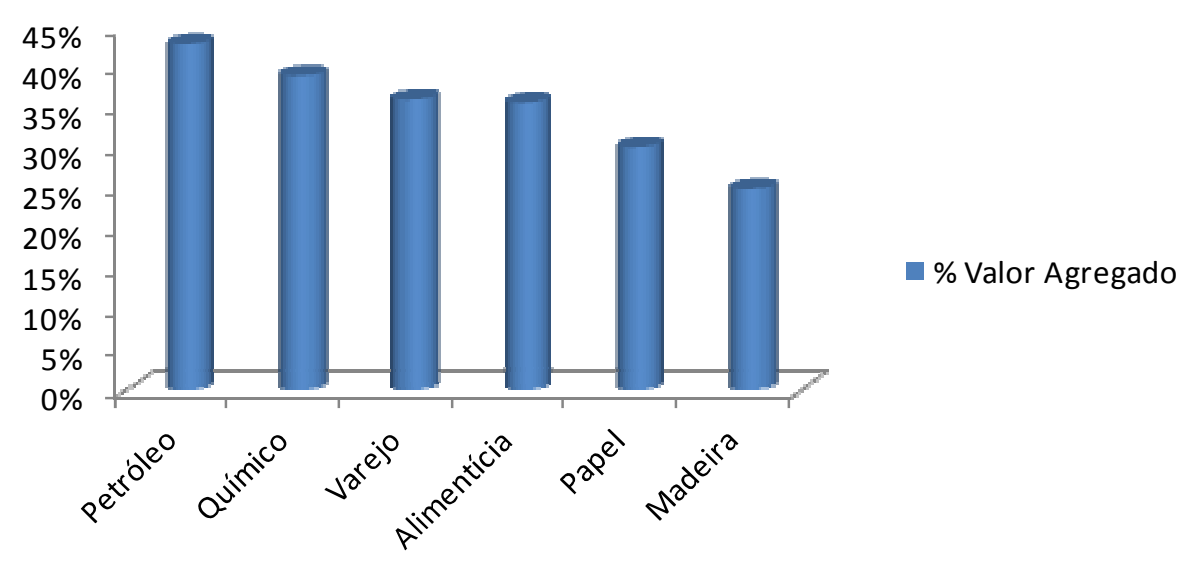

Figura 02 - Percentual dos Custos Logísticos no Valor Agregado Fonte: Adaptado de Lambert et al. (1998).

A indústria do petróleo por sua vez possui uma enorme representatividade na economia mundial, visto que, de acordo com a Forbes Magazine (SCOTT, 2012), quatro das dez maiores companhias do mundo são de petróleo e gás. Dentro destas quatro empresas encontra-se a Petrobras, uma empresa de petróleo brasileira, que está colocada em décimo lugar nesta lista. 
A indústria do petróleo, por ter uma volatilidade alta de preços e pelo produto ser completamente estratégico para todos os países, se torna um ponto de grande importância tanto para as empresas quanto para os governos onde elas estão localizadas. Uma forma de amortecer os impactos negativos da volatilidade dos preços é reduzir os custos associados ao produto.

Contudo, como já mencionado anteriormente, a gestão de custos nas empresas em geral, não é estruturada de tal modo que auxilie os gestores na redução e na busca pela eficiência dos processos.

\section{1 \\ Relevância}

Na Petrobras o quadro não é diferente, atualmente a gestão de custos é feita pelos custos totais das operações. Alguns desdobramentos são feitos para os maiores custos, tais como o Custo do Dowstream (parte da cadeia de óleo e gás que realiza as atividades de transporte, refino e comercialização). Ainda desdobrando este custo, temos o Custo da Logística do Downstream que representa aproximadamente 3\% da Receita Total da empresa (fonte: Relatório Financeiro da Petrobras 2010 e Controles Internos da Logística do Abastecimento da). Todavia, estes custos não são relacionados às atividades de entrega, produção e movimentações em geral. Com isso, não se tem facilidade de enxergar as ineficiências dos processos, quais canais estão sobrecarregando os custos totais e nem mesmo onde estão os gargalos de entrega.

Dando sequência ao trabalho iniciado por Moreira (2008), onde foram sugeridas ferramentas de análise de custos existentes na literatura para serem aplicadas na Petrobras, a proposta do atual trabalho é desdobrar a aplicação do custo ABC (Activity Based Cost), ora proposto, no Custo para Servir (CTS - Cost to Serve). O Custo ABC é uma ferramenta onde os custos são alocados por atividade, enquanto que o Custo para Servir é a verificação dos custos, já alocados por atividade, até a chegada ao cliente, tendo como um dos seus objetivos a visualização da rentabilidade de cada cliente. No trabalho de Moreira (2008) foi aplicada a metodologia aos custos de transporte marítimo, que representam grande

parte dos custos Logísticos do Abastecimento. Neste trabalho a pretensão é 
estender para todos os custos logísticos do Abastecimento, alocá-los conforme metodologia $\mathrm{ABC}$ e posteriormente propor a aplicação da metodologia de avaliação do Custo para Servir.

\section{2 \\ Objetivos e Delimitação do Trabalho}

O presente trabalho tem como objetivo propor a implementação de uma metodologia para medição dos Custos relacionados à área da Logística do Abastecimento de petróleo e derivados que possa dar suporte às tomadas de decisões estratégicas da Petrobras, visando à melhoria dos processos e, consequentemente, a lucratividade e a competitividade da empresa.

O objetivo principal deste trabalho é viabilizar conceitualmente a implementação de uma metodologia de Gestão de Custos, possibilitando o desenvolvimento de um sistema informatizado para medição do Custo para Servir, tendo em vista a Governança envolvida nesta Gestão.

Além disso, o trabalho poderá trazer uma melhor visão da cadeia logística, uma clarificação das restrições operacionais presentes nos processos, a identificação de quais clientes são mais ou menos rentáveis para empresa, quais canais de distribuição apresentam alto custo de operação, entre outros objetivos secundários que auxiliariam na melhoria contínua dos processos logísticos.

O trabalho consistiu na pesquisa bibliográfica, seguida do mapeamento das atividades envolvidas na Logística do Abastecimento da Petrobras. Após o mapeamento, foram levantados os possíveis direcionadores de custo neste âmbito e com base técnica foi realizado uma proposta de métricas de custos associada a uma ferramenta de análise.

Nenhum trabalho foi encontrado na literatura que tenha focado a implantação da metodologia do Custo para Servir na indústria de petróleo, com isso este trabalho pode contribuir em termos acadêmicos no que diz respeito à aplicabilidade deste método neste tipo de indústria, assim como recomendar futuros estudos a respeito desta implantação no case focado no presente trabalho.

A literatura contempla trabalhos aplicados, por exemplo, na indústria de eletrônicos, onde foi possível o aumento da rentabilidade, mesmo sendo um 
mercado de baixa margem (Smith, 2006). Outra aplicação foi na indústria alimentícia, onde foi possível a revisão da política comercial que se redefiniu como atender os clientes, alavancando também a rentabilidade (Guerreiro et al., 2008). Outros trabalhos são mencionados ao longo da revisão bibliográfica que seguirá o Capítulo 2.

\section{3}

\section{Estrutura do Trabalho}

O segundo Capítulo contém a revisão bibliográfica sobre Cadeia de Suprimento e Logística, Custos (com foco no ABC e Custo para Servir) e ainda avaliação de desempenho com foco na Logística.

O terceiro Capítulo apresenta a empresa de estudo, no caso a Petrobras, assim como a Gestão de Custos atualmente aplicada. No quarto Capítulo são explorados os conceitos da metodologia do Custo para Servir e possíveis aplicações na empresa, assim como os levantamentos das atividades da Logística do Abastecimento e os custos envolvidos nestas atividades. Finalizando, o Capítulo cinco apresenta a aplicação na empresa, seguida do Capítulo seis com as conclusões, as considerações finais e as recomendações. 


\section{2 \\ Revisão Bibliográfica}

Este Capítulo tem por objetivo levantar as principais referências bibliográficas dos assuntos que dizem respeito a este trabalho, tais como Cadeia de Suprimento e Logística, Gestão de Custos, visando principalmente o Custo para Servir e Indicadores de Desempenho.

\section{1 \\ Cadeia de Suprimento e Logística}

Desde a Antiguidade até os dias de hoje, o mercado consumidor não está fisicamente próximo ao mercado produtor para grande parte dos produtos consumidos no mundo (Ballou, 2006). Isto se dá por diversas razões e as atividades logísticas existem para encurtar este espaço, seja por meio do armazenamento de produtos próximos aos locais de consumo ou através de meio de transporte eficiente.

Ballou (2006), ainda cita atividades tais como transporte, armazenagem, manuseio de materiais, embalagem, padrões de serviço ao cliente e programação da produção como atividades englobadas pela Logística. Então, a Logística, com seus processos internos coordenados, visam "encurtar" a distância entre fornecedores e consumidores.

A palavra logística tem diferentes significados em diferentes línguas: em grego, logos significa discurso, razão, rácio, racionalidade, linguagem, frase, e logistiki tem sua tradução como contabilidade e organização financeira; já no francês, loger (um verbo) é traduzido como alojar ou.

Ainda ao verificar o Dicionário de Cambridge, encontra-se a definição de logística como a "organização cuidadosa de uma atividade militar, de negócios, 
ou outra, para que tudo aconteça de forma bem sucedida e eficaz" (Dicionário Cambridge, 2012). Alguns autores afirmam que a origem desta ciência se deu nas diversas guerras ocorridas pelo mundo afora. A necessidade de atendimento rápido e eficaz às bases militares, estrategicamente posicionadas, era fundamental para ter resultados positivos nas batalhas. Alimentos, armas e munição eram os principais produtos movimentados pelos militares e o fluxo destes produtos deveria ser minuciosamente planejado, para não haver falhas nas entregas, que poderia acarretar num exército despreparado para os confrontos. Essa ciência desenvolvida foi sendo aperfeiçoada ao longo dos anos, se tornando essencial para toda e qualquer organização. Hoje, as entregas que não podem falhar são os atendimentos aos clientes das organizações. Com a globalização, houve o aumento da concorrência, o que levou os clientes a serem mais exigentes, tanto em qualidade, quanto em urgência no recebimento do produto desejado. Atrelado a este atendimento há um custo envolvido, cabendo então às áreas de Logística das companhias a obrigação de orquestrar todo esse fluxo de informação e de produtos, objetivando sempre a forma mais eficiente e eficaz de realização.

Uma das entidades referentes no mundo em Logística o Conselho de Profissionais de Gerenciamento da Cadeia de Suprimento, o CSCMP (Council of Supply Chain Management Professionals), uma organização sem fins lucrativos, conhecida por desenvolver profissionais envolvidos com Logística e Cadeia de Suprimento, define, em seu sítio, Logística como sendo

\footnotetext{
[...] o processo de planejamento, implementação e controle de procedimentos para a eficiência e efetividade do transporte e estocagem de produtos, incluindo serviços e informações relacionadas desde o ponto de origem até o ponto de consumo de forma a atender as expectativas dos clientes. Esta definição inclui os movimentos de logística de abastecimento (ou inboud) e distribuição (ou outbound), além dos movimentos internos e externos (Council of Supply Chain Management Professionals, 2012).
}

Um dos pontos que o CSMP não cita em sua definição e que é claramente exposto por alguns autores é a necessidade do ser economicamente eficaz.

Bowersox e Closs (2007) corroboram afirmando que o produto deve chegar às mãos dos clientes ao menor custo possível. Vale notar que estes autores ainda apontam que "a criação de valor logístico envolve alto custo", sendo esta área responsável por 5 a 35\% do valor de vendas. 
A logística integrada, por sua vez, é definida pelo CSCMP como sendo a visão de toda a cadeia de suprimento, como um único processo, a ser gerido pela mesma entidade. Todos os processos, desde a obtenção da matéria prima até a distribuição do produto acabado devem ser contemplados nessa mesma visão. A gestão da Logística Integrada engloba o planejamento, implementação e controle dos fluxos de saída e logística reversa, além da estocagem, armazenamento de produtos, serviços e informações entre o ponto de origem até o ponto de consumo, com o propósito de atender as necessidades dos clientes.

A Logística Integrada é representada esquematicamente, segundo Bowersox e Closs (2007), conforme Figura 03:

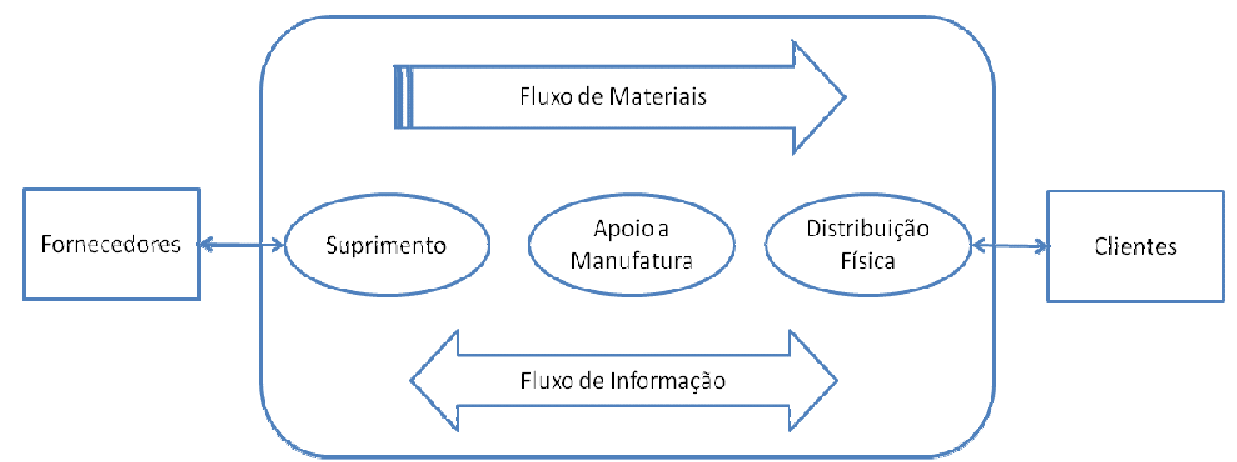

Figura 03 - Logística Integrada

Fonte: Adaptada de Bowersox e Closs (2007).

Essa figura mostra que a Logística Integrada pode ser representada pelos processos de dentro da própria empresa (suprimento, apoio a manufatura e distribuição física), onde interagem entre eles através do fluxo da informação e o fluxo dos materiais. A Logística se estende além dos limites da empresa no momento da troca com seus fornecedores e clientes. Com este processo integrado, o fluxo acontece de forma mais eficiente e eficaz.

Logo, a Gestão da Cadeia de Suprimento é considerada pelo CSCMP como a parte que abrange, além da Gestão da Logística Integrada, todo o planejamento e gestão das atividades de procurement e sourcing, produção, incluindo a coordenação e colaboração de parceiros, que podem ser fornecedores, intermediários, terceiros e clientes. Dentro da empresa, compreende ainda a integração dos processos de vendas, marketing, desenho de produtos, finanças e tecnologia da informação. 
Para Ballou (2006) a logística possibilita a criação de valor para o cliente, fornecedor e acionista. O primeiro vê valor quando tem a possibilidade de obter o produto que deseja, no local e tempo desejado para consumi-lo.

Sendo assim, o atendimento ao cliente é o principal objetivo da Logística, fazendo com que este processo seja um diferencial entre as empresas, promovendo uma vantagem competitiva onde é feito de forma efetiva e eficaz.

Segundo os autores Bowersox e Closs (2007) o serviço logístico pode ser medido em termos de disponibilidade, desempenho operacional e confiabilidade no serviço,onde disponibilidade é ter estoque de um produto, desempenho operacional é o tempo que se leva para entregar este produto desde seu pedido e confiabilidade é junção dos dois primeiros fatores.

Heskett (1994) descreve o serviço ao cliente como a velocidade e a confiabilidade que um produto chega às mãos dos seus clientes. A confiabilidade no fornecedor é uma característica imprescindível que vem sendo levantada por inúmeros autores, levando a crer que os clientes buscam esta característica nos seus fornecedores, portanto isto deve ser objetivado pelas empresas visando à fidelidade de seus clientes.

Pesquisas realizadas por Sterling e Lambert (1989) e Innis e LaLonde (1994) em diferentes indústrias mostraram que as principais características de prestação de serviço valorizadas pelos clientes estavam diretamente relacionadas à Logística, tais como cumprimento da data acordada de entrega e tempo de resposta adequado.

Como vivencia-se um cenário com alta competitividade, os clientes são os maiores beneficiados, visto que podem, por exemplo, exigir tempos de resposta mais curtos, que terão esses tempos atendidos por algum fornecedor. Os fornecedores visam cada vez mais melhorar seus processos para satisfazer e fidelizar seus clientes. Contudo, essa busca da melhoria no atendimento tem custo a ela associado.

Ballou (2006) afirma que para todo nível de serviço que uma empresa pretende prestar ao seu cliente está associado um custo a ele. Ainda ressalta que o custo aumenta quase que exponencialmente à medida que se aumenta o nível de serviço e que caso estes níveis de serviço e os custos forem conhecidos é possível, matematicamente, calcular o nível de serviço ótimo visando à maximização dos lucros da empresa. 


\section{2 Gestão de Custos}

De acordo com Jeffery et al. (2008), o foco da logística integrada é disponibilizar produtos de qualidade, no prazo e quantidades acordadas, visando atender o nível de serviço oferecido ou contratado ao menor custo logístico total que se possa incorrer na operação de entrega. Qualquer exigência ou serviço ofertado para o cliente tem um custo associado. E. Gorsvenor Plowmam (apud Lambert et al. 1998), explicita os cinco certos da logística: "fornecer ao consumidor o produto certo no lugar certo no momento certo e nas condições certas pelo custo certo".

Por isso, é importante que estes custos estejam claros para a empresa, como falam Kaplan e Cooper (2000).

Nos próximos itens deste Capítulo é dada ênfase na gestão de custos em geral, assim como aprofundamento no Custeio Baseado em Atividades (ABCActivity Based Cost) e Custo para Servir.

\subsection{1 \\ Custos em Geral}

Braithwaite e Samakh (1998) sustentam que as questões sobre a cadeia de suprimentos são expressas pelas organizações de tal forma que reflitam as principais percepções internas para auxílio nas tomadas de decisão. Afirmam ainda que essas questões estão relacionadas e que os principais temas devem ser tratados, são eles: custo da variedade, gerenciamento do cliente, objetivo de atendimento ao cliente, rotas de suprimento, estrutura de redes, política de preços e comercial; e, custos funcionais e recompensas de pessoal.

Para o Custo da Variedade apontam que diferentes produtos não contribuem igualmente na rentabilidade da empresa. A preferência da área comercial de uma empresa, sempre é ter uma alta variedade de produtos, contudo, se os custos não são conhecidos, não se pode avaliar a real contribuição daquele produto. 
No caso de Gerenciamento de Clientes, mostram que as empresas tem grandes e pequenos clientes, que apresentam custos diferenciados de servi-los.

Em relação ao Objetivo de Atendimento ao Cliente, argumenta-se que o compromisso que a empresa assume com seus clientes serve de base para seu posicionamento no mercado, assim como para definição estratégica e estruturação da sua cadeia de suprimentos. Observaram também que uma mesma cadeia de suprimento não deve atender a diferentes canais, sendo que cada canal se associa a um grupo de clientes com características semelhantes. Para eles, o princípio é segmentar os clientes da empresa em diferentes canais, mas para que tudo isso ocorra é necessário que a empresa conheça por completo os custos da cadeia.

Referindo-se agora a Rotas e Estrutura de Redes, afirma-se que atualmente as ações em relação às redes são voltadas para a racionalização e downsizing. No futuro, as operações serão voltadas para a dinâmica da cadeia de suprimento. As rotas serão ajustadas pela característica da ordem, assim como o nível de serviço acordado e a disponibilidade de produto na cadeia. Estas ações implicarão na redução de estoques locais e conhecimento total dos custos para servir alguns canais.

As questões sobre Política Comercial e de Preços são consideradas por Braithwaite e Samakh (1998) como pontos que dependem da análise estratégica sobre a rentabilidade, que está relacionada à combinação de produtos, clientes, rotas logísticas e política de preços. Pois estes objetos podem suprimir a margem planejada para uma parte do negócio.

Finalizando os temas levantados por Braithwaite e Samakh (1998), os Custos Funcionais e Recompensas de Pessoal são abordados pelo pensamento que a cadeia de suprimentos requer um balanço entre as funções, através do alcance de metas de desempenho e medições de custo. Essas duas variáveis tem que ser complementares para que não fomentem a geração de resultados opostos para a empresa.

Todos os pontos levantados levam a acreditar que os custos da cadeia de suprimento devem ser medidos em detalhes e há a necessidade da existência de ferramentas para tal. Todos os principais aspectos de uma cadeia de suprimento têm relacionados a eles os custos. Para gerenciar uma cadeia de suprimento, se faz necessário o conhecimento destes custos, visto que, atualmente, não se pode buscar apenas uma eficiência operacional, o mercado competitivo faz com que as 
empresas busquem um melhor resultado econômico. O objetivo de uma cadeia logística é entregar o produto certo, na quantidade e qualidade corretas, no momento adequado ao menor custo possível.

Inicialmente o método de custeio tradicional e simples, de custos fixos e mão-de-obra direta, visava atender somente a legislação, atendendo às regras e exigências dos governos. Kaplan e Cooper (2000) afirmam que este método auxilia somente em uma das três principais funções de um sistema de custeio, na função de ser base dos relatórios financeiros, com as informações de avaliação de estoques e custos dos produtos vendidos. As outras duas funções são as de provisionar despesas e a de medir a eficiência dos processos.

Quando um custo não pode ser identificado de maneira conveniente ou econômica, em algum grupo e/ou objeto de custo, Blocher et al. (2007) designam este custo como indireto. Já o processo de apropriar este custo indireto, utilizando direcionadores de custo é conhecido como alocação de custo.

No ponto de vista de Kaplan e Cooper (2000), a alocação dos gastos gerais, consideradas na metodologia tradicional como custos fixos, é realizada inadequadamente aos produtos finais. Analogamente, a metodologia de custos diretos, utiliza somente os custos diretamente ligados à produção, ignorando os outros e assumindo que estes são indiretamente proporcionais ao volume de produto vendido. Assim alocados, estes custos não auxiliam nas duas últimas funções de provisionar despesas e medir a real eficiência dos processos.

Os sistemas de contabilidade de custos fornecem informações de "Custo do Produto", que contemplam somente os custos necessários para produção. Blocher et al. (2007) citam materiais diretos, mão-de-obra direta e custos indiretos de fabricação (de apoio à produção) como itens a serem considerados no custo do produto. Já nas empresas comerciais, afirmam ainda que se deve incluir o custo da aquisição e transporte.

Estes sistemas também fornecem informações para apuração dos "Custos do Período", que englobam, além do Custo do Produto, os gastos com administração e venda do produto (Blocher et al. (2007).

De acordo com Blocher et al. (2007), os sistemas de custeios de produtos podem ser de três diferentes tipos: pela acumulação de custos (custeio por processo ou ordem); medição de custos (custeio real, normal ou padrão) e apropriação de custos indiretos de fabricação (custeio $\mathrm{ABC}$, baseado em 
atividades). O processo de custeio de produtos se dá de forma que materiais diretos, mão-de-obra direta e custos indiretos de fabricação aos produtos e/ou serviços possam ser acumulados, classificados e apropriados.

O Custeio por Acumulação de Custos é sistematizado de forma com que todos os custos sejam apropriados às ordens de produção ou a processos, onde estes são os objetos de custo. De acordo com Blocher et al. (2007), quando apropriados a processo, este sistema se adequa bem a empresas que produzem continuamente produtos homogêneos e em larga escala. Já pequenas e médias empresas que atendem pedidos individuais devem ajustar seus sistemas para apropriação dos custos a ordens, assim os resultados podem ser mais bem analisados estrategicamente.

Blocher et al. (2007) ainda afirmam que o Custeio por Medição pode ser avaliado por Custeio-padrão, Normal ou Real. No Custeio-padrão, o sistema utiliza valores de custo que a empresa deve atingir e não os valores que realmente praticou. Este tipo de sistema é utilizado para medir o desempenho, controlar custos e melhorias de processo.

Diferentemente, o sistema de custeio real visualiza os valores de custos de produto reais medidos no período, levando em consideração materiais diretos, mão-de-obra direta e custos de fabricação. Já o Custeio Normal utiliza para materiais e mão-de-obra diretos o custo real, e para os custos de fabricação se utiliza uma estimativa.

O sistema de custo real não é largamente utilizado, pois gera distorções na formação de preços, visto que é influenciado pelas flutuações de custos unitários de produção.

Com o novo cenário global onde se faz necessário um conhecimento mais apurado e estratificado dos custos de uma empresa, surgem então, em meados de 80 , os sistemas de custeio baseados na atividade, conhecidos mundialmente como "Custeio ABC - Activity Based Cost". Associados a estes sistemas emergem também os gerenciamentos baseados na atividade (ABM - Activity Based Management): operacional e estratégico. Kaplan e Cooper (2000) mostram que o primeiro auxilia no aprimoramento operacional e o segundo influencia nas decisões estratégicas de uma companhia.

Ainda nessa mesma linha de considerações, Bowersox e Closs (2007) com informações de estudos práticos de custos logísticos, afirmam que os custos totais 
deveriam ser mais bem analisados quando fossem avaliados pelos custos funcionais, focando o custeio baseado em atividades. Contudo, ainda afirmam que é um desafio medir os custos logísticos totais e que os modelos atuais de contabilidade restringem este tipo de análise.

Lambert e Burduroglu (2000) afirmam que o custo total não deve ser utilizado como medida de desempenho, pois não reflete a receita associada diretamente a este custo.

Já o Custo para Servir pode mostrar a rentabilidade por cliente, por canal ou, por exemplo, por região geográfica, conforme mencionado anteriormente, com isso, este pode ser um método de auxílio na gestão por custos.

Outras métricas, apresentadas na Tabela 01, assim como CVA (Customer Value Added), Custo Total, EVA (Valor Econômico agregado) são amplamente utilizadas para medição do desempenho operacional. Lambert e Burduroglu (2000) fazem um comparativo entre essas métricas:

\begin{tabular}{|l|l|l|}
\hline Métrica & Vantagem & Desvantagem \\
\hline $\begin{array}{l}\text { CVA (Customer Value } \\
\text { Added) }\end{array}$ & $\begin{array}{l}\text { Noção de valor além do } \\
\text { preço } \\
\text { Fácil Implementação }\end{array}$ & $\begin{array}{l}\text { Não mensura impacto } \\
\text { financeiro ao ofertar } \\
\text { alto valor ao cliente }\end{array}$ \\
\hline Custo Total (Total Cost) & $\begin{array}{l}\text { Pode ser usado para } \\
\text { medição do desempenho } \\
\text { logístico interno e externo }\end{array}$ & $\begin{array}{l}\text { Ignora o nível de } \\
\text { receitas associada aos } \\
\text { custos }\end{array}$ \\
\hline $\begin{array}{l}\text { Custo para Servir (Cost to } \\
\text { serve) }\end{array}$ & $\begin{array}{l}\text { Abrange os custos de } \\
\text { canal de venda / } \\
\text { segmentação de clientes }\end{array}$ & $\begin{array}{l}\text { Necessidade dos } \\
\text { custos das atividades } \\
\text { que compõe os } \\
\text { processos, canais de } \\
\text { venda, etc. }\end{array}$ \\
\hline $\begin{array}{l}\text { Análise por lucratividade } \\
\text { de segmento }\end{array}$ & $\begin{array}{l}\text { Receitas e desembolsos } \\
\text { são considerados para } \\
\text { análise da segmentação } \\
\text { da demanda }\end{array}$ & $\begin{array}{l}\text { Não mensura custos } \\
\text { de ativos empregados }\end{array}$ \\
\hline
\end{tabular}

Tabela 01 - Métricas de Análise de Custos

Fonte: Adaptado de Lambert e Burduroglu (2000).

Assim como Lambert e Burduroglu (2000), os autores Guerreiro et al. (2011) corroboram com as análises em relação às métricas existem e ainda acrescentam o Valor Econômico Adicionado (EVA), o Custeio Baseado em Atividades (ABC) e Análise de Rentabilidade (AR) como ferramentas de análise econômica das empresas. Mencionam ainda em seu artigo que alguns autores salientam a importância do uso do ABC como uma ferramenta onde os custos são 
visualizados mais claramente, facilitando análises críticas sobre os processos e atividades para as quais os custos estão sendo alocados. Contudo, Lockamy e Smith (2000) consideram que esta metodologia deixa a desejar no que diz respeito a uma análise mais detalhada sobre a satisfação dos clientes. Guerreiro et al. (2011) complementam afirmando que o Custo para Servir é uma métrica que pode ser utilizada no auxílio para este tipo de análise, relacionando o nível de serviço (diretamente proporcional à satisfação aos clientes) com o custo total.

O custo total como ferramenta de análise se faz ineficaz quando não leva em consideração as receitas associadas, pois a rentabilidade por cliente, canal, etc. é vista como uma métrica importante nas tomadas de decisão quando o ambiente é competitivo e há necessidade de, além de reduzir custos, tornar os processos mais eficazes.

As métricas existentes não são completas no que diz respeito a uma análise global de uma empresa. Por muitas vezes se faz necessário a análise conjunta de todas estas ferramentas para maior esclarecimento sobre os custos desta empresa.

Outra metodologia apresentada por Faria e Costa (2005) é a rentabilidade Direta por Produto (Direct Product Profitability - DPP), onde são atribuídos somente os gastos que podem ser diretamente alocados ao produto, desconsiderando alguns custos fixos. Assim, esta metodologia não representa os Custos Totais Logísticos. Ainda afirmam que Reeve (1998), desenvolveu outra metodologia para medição dos custos que tem como objetivo o relacionamento com os clientes. Esta metodologia foi chamada de Custo Total de Entrega (Total Cost of Delivery - TCD).

O Custo Total de Entrega leva em consideração o Custo Total de Propriedade (Total Cost Ownership -TCO), que é o custo total adquirido de um fornecedor, mais o Custo para Servir. Ainda segundo Reeve (1998), o escopo desta abordagem é entre cadeias de suprimento e um dos objetivos é alinhar recursos logísticos e de marketing.

A seguir será detalhado o método de Custeio $\mathrm{ABC}$, assim como o Custo para Servir que é decorrente do ABC.

\subsection{3}

\section{Custeio ABC}


O custeio Baseado em Atividades teve início quando foi possível perceber o aumento significativo do overhead, que são os custos indiretos comuns. A alocação destes custos indiretos estava mascarando os reais custos dos produtos.

Como mencionado anteriormente, para a contabilidade gerencial, estes custos do overhead são alocados através de rateio, na maioria dos casos, conforme ilustrado na Figura 04 que mostra uma forma representativa do custo por absorção.

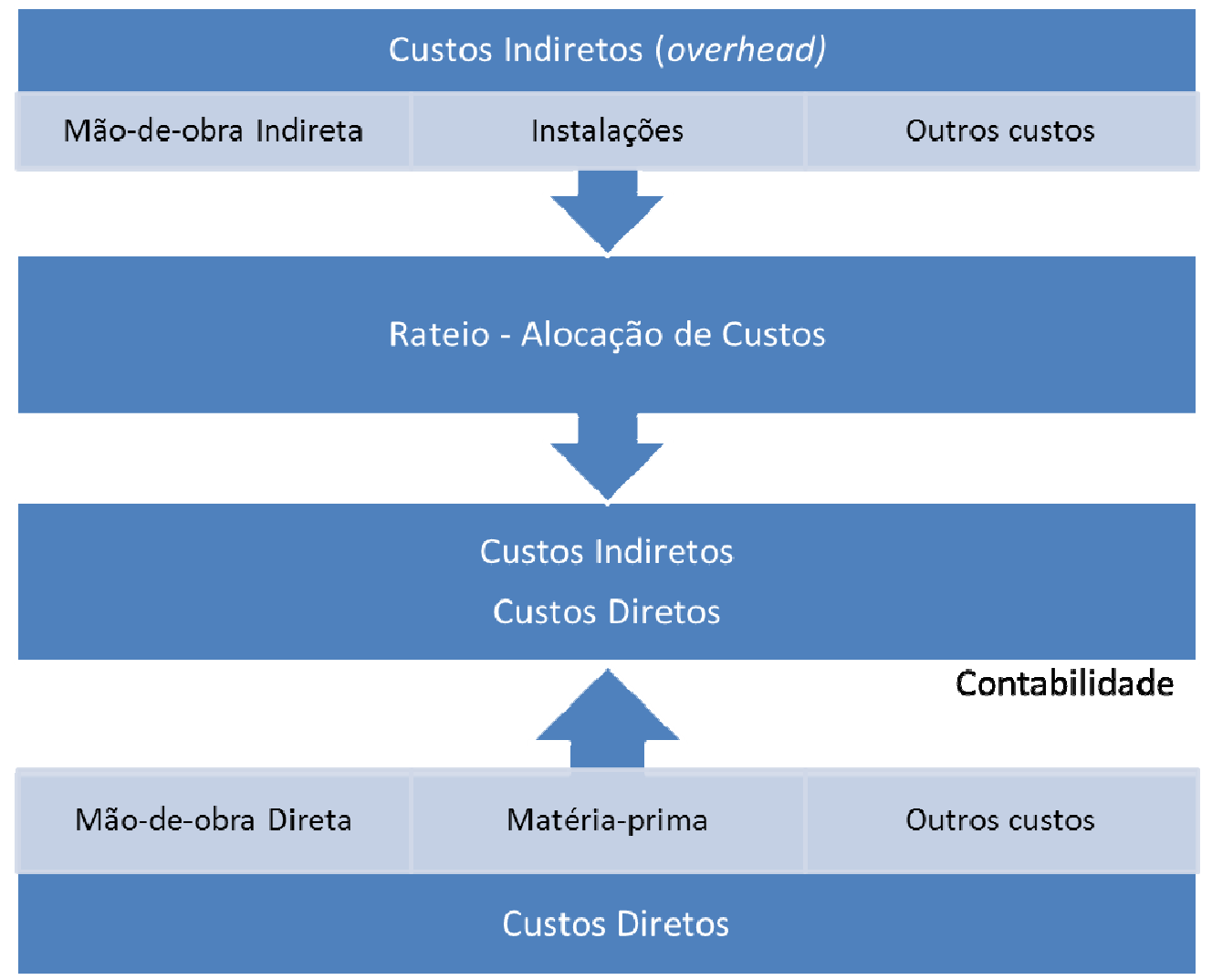

Figura 04 - Esquema ilustrativo do Custeio por Absorção Fonte: Adaptado de Martins (2003).

Como mencionado por Faria e Costa (2005), através de direcionadores de custo, os chamados "cost-drivers", pode-se atribuir os custos dos produtos e serviços de acordo com o que realmente estes consomem de recursos (processos, atividades e tarefas).

Primeiramente, devem-se identificar as atividades que estão sendo praticadas pelos recursos indiretos e de apoio, estando estas atividades bem definidas dentro do ambiente de produção, conforme salientam Kaplan e Cooper (2000). Estes autores ainda afirmam que, posteriormente, devem ser utilizados direcionadores de custo de recursos, onde cada despesa é alocada às atividades 
relativas a ela de acordo com o percentual de utilização daquele recurso naquela atividade.

Ao referir-se a atividade, Faria e Costa (2005) definem como sendo todas as etapas pelas quais um produto ou serviço devem passar para que sejam entregues para um determinado cliente. Essas atividades pelas quais o processo passa agregam valor a este produto e serviço.

Então, para cada despesa deve haver um direcionador de quanto percentualmente esta despesa/recurso é utilizada em uma determinada atividade. Assim, seu custo será rateado de forma ponderada às atividades que a consomem.

Kaplan e Cooper (2000) continuam desenhando o processo de implementação do método $\mathrm{ABC}$ com a etapa seguinte, que é a de associação dos clientes e produtos/serviços a estas atividades, com intuito de verificar a remuneração justa para cada produto/serviço entregue. Caso sejam produtos de maior "consumo" de atividades, estes têm que ser mais valorizados pelo cliente/mercado.

Para terminar, deve-se determinar um direcionar de custo da atividade aos clientes e produtos/serviços, sendo esta uma medida quantitativa do resultado da atividade. Um exemplo de direcionadores, que Faria e Costa (2005) chamam de "causadores de custo", pode ser o volume movimentado ou até mesmo a quantidade de funcionários envolvidos em cada atividade.

A Figura 05 demonstra esquematicamente o funcionamento da alocação dos custos no modelo ABC. 


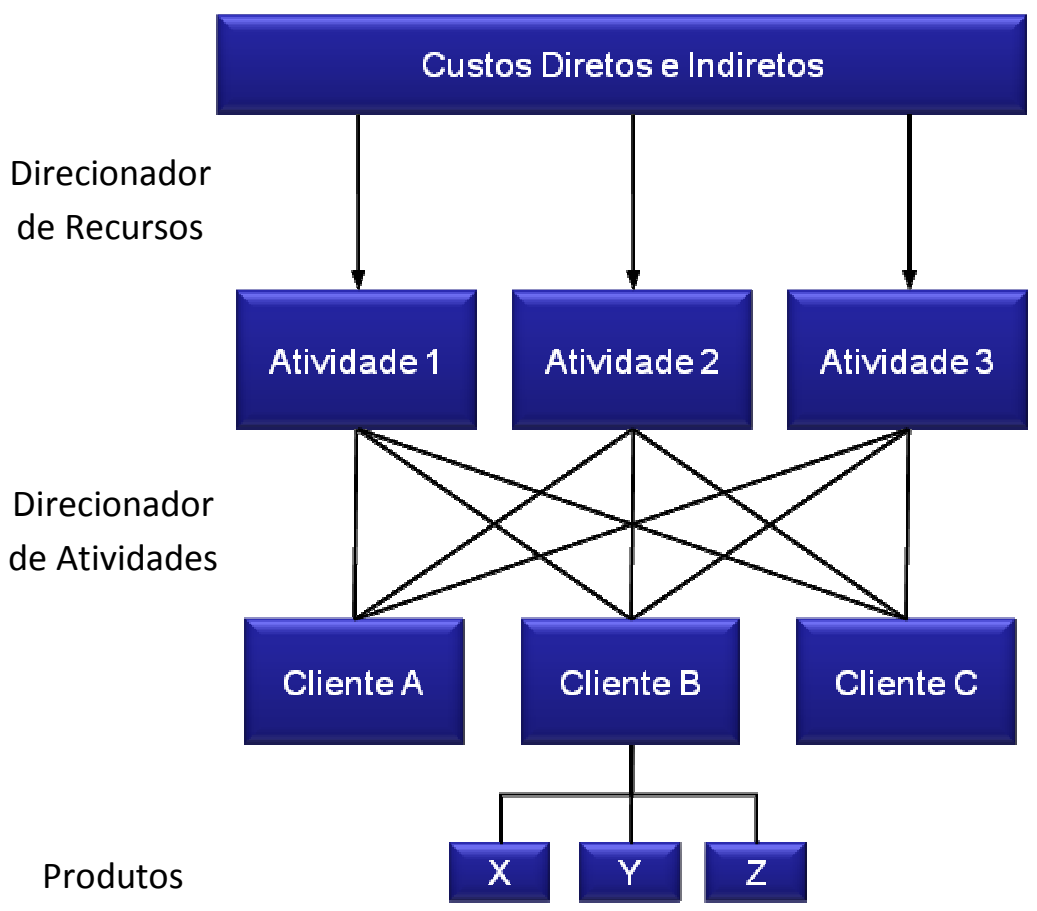

Figura 05 - Esquema ilustrativo da Alocação de Custos no Sistema ABC Fonte: Adaptada de Nakagawa (2001).

Através dos direcionadores, os custos são alocados aos objetos de custo, que no exemplo anterior foram considerados os clientes e produtos.

Com o método de custeio ABC aplicado, pode-se utilizar desta ferramenta para aprimoramento da gestão, baseando-se nos resultados para agir no sentido de melhor utilização dos recursos, objetivando um custo total menor. Este processo é chamado por Kaplan e Cooper (2000) de Acticity Based Management (ABM), podendo ter o foco operacional ou estratégico, conforme já mencionado anteriormente. Para a gestão operacional é possível aumentar a capacidade, reduzir necessidade de recursos e tempos de ressuprimento, enfim, otimizar os processo de produção e distribuição. Na visão estratégica, há possibilidade de visualização clara de pontos de venda ou produtos que geram prejuízo para empresa, podendo ser revista a posição em relação a eles. Quando se enxerga o todo, há compensações de resultados e quando se estratifica, os resultados negativos ficam evidenciados. O posicionamento estratégico da empresa pode mudar radicalmente frente a estes resultados claros.

O modelo de custeio ABC pode ser aplicado também a cada cliente, quando as despesas são direcionadas aos clientes. Kaplan e Cooper (2000) afirmam que, através da margem líquida, medida pela diferença entre o preço 
líquido e os descontos e custos de produção (custos baseados no modelo ABC de custeio), confrontada com o custo do cliente (custo de pedidos, marketing, despesas administrativas, etc. todos calculados pelo custeio $\mathrm{ABC}$ de clientes) pode-se fazer a administração de seus clientes. A Figura 06 ilustra o modelo de administração dos clientes.

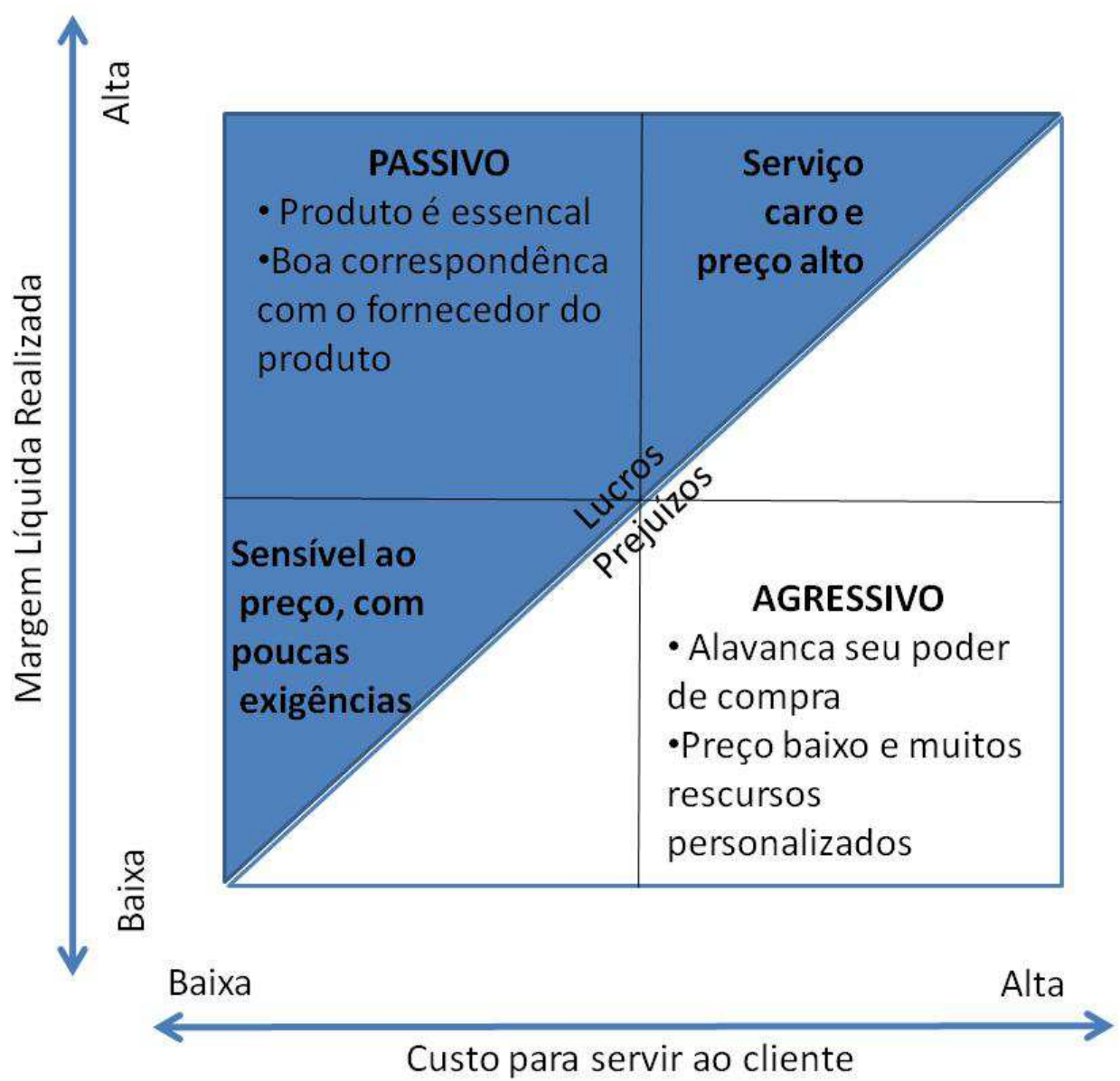

Figura 06 - Administração de clientes com base no custo do cliente e sua margem Fonte: Adaptada de Kaplan e Cooper (2000).

O ideal de se trabalhar é com clientes que exigem pouco, consequentemente o custo para servir é baixo e possuem margem de lucros alta (preços altos). O quadrante superior esquerdo mostra esse cliente. Para alguns clientes não há alternativa de aumentar seus preços, pois compram volumes altos, pode-se trabalhar para alcançar então baixos custos para servi-los.

O modelo de custeio $\mathrm{ABC}$ serve então como base do custo para servir os clientes e deve ser usado para delinear o relacionamento com os clientes, delimitando preços, canais de distribuição, mix de produtos, etc. 
Kaplan e Cooper (2000) ainda mencionam que a empresa Procter \& Gamble e Pillsbury utilizaram o método de custeio ABC para medir o custo para servir seus clientes, assim puderam precificar cada produto/serviço de acordo com os custos associados, além de reduzir custos de operações que não geravam valor para suas empresas.

Guerreiro et al. (2008) também realizaram um estudo numa indústria de alimentos no Brasil, onde aplicaram o modelo do custo para servir, objetivando a análise de rentabilidade dos clientes desta indústria. Constataram que este modelo auxilia na tomada de decisão, na política de atendimento e na eficácia para atender aos níveis de serviço requeridos.

O caso Kanthal, uma indústria sueca, estudado por Kaplan (1989), foi um dos pioneiros no que diz respeito à mensuração dos custos para servir baseado no método de custeio ABC.

\subsection{4 Custo para Servir}

A metodologia do Custo para Servir tem como um dos seus objetivos principais identificar quais os clientes mais rentáveis, assim como rotas e pontos de distribuição, auxiliando com isso as decisões gerenciais (Faria et al., 2010).

O Custo Para Servir, ou CTS (Cost to Serve), é um método que aprofunda o tratamento da rentabilidade dos clientes através do aperfeiçoamento dos sistemas da empresa. É necessária a aplicação de tecnologia, para que através da determinação do nível de serviço estabelecido para os clientes, se possa identificar a rentabilidade de cada um deles. Essa visão é compartilhada por vários autores assim como Milone (2001), Faria e Costa (2005) e Guerreiro et al. (2008).

O Custo para Servir, conforme já mencionado, está relacionado diretamente com a análise de rentabilidade de clientes e uma das formas que as empresas medem essa rentabilidade, segundo Sharman (1996), é pela margem de contribuição. Este conceito é utilizado com base no método de custeio variável. Já a margem de lucro bruto utiliza o método de custeio por absorção. Ambas as metodologias têm como objetivo a mensuração do custo de fabricação dos produtos, que por sua vez é maior alvo de estudo dos custos relacionados às atividades comerciais e de logística. Estes dois últimos custos compõem o Custo 
para Servir o cliente. Contudo, Norek e Pohlen (2001) afirmam que as empresas ainda sentem falta de uma ferramenta que mostre o custo e rentabilidade de seus clientes.

Os custos relacionados a vendas, marketing, distribuição e administrativos (VDMA) devem ser alocados aos objetos de custo, segundo Kaplan e Cooper (2000), e Christopher (2007). Contudo, esse custos não são considerados fixos, mas também não são variáveis, dado que não são diretamente proporcionais ao volume. No sentido de simplificar, Anderson e Kaplan (2004) recomendam que sejam alocados pelo tempo gasto nas atividades, o chamado time-driven $\mathrm{ABC}$. Neste caso o direcionador do custo é o tempo.

Norek e Pohlen (2001), Braithwaite e Samakh (1998) afirmam que, a base do Custo para Servir é o método de custeio $\mathrm{ABC}$, que é o método de custeio por atividades, onde se apropria os recursos às atividades relacionadas a eles, ligando posteriormente os custos das atividades aos objetos de análise, tais como clientes, canais de distribuição, rotas, modais de transporte, etc. O mesmo falam Kaplan e Narayanan (2001) sobre a relação das atividades com os objetos de custeio já mencionada, que proporciona uma informação mais clara, detalhada e precisa sobre as margens brutas e os Custos para Servir, agregando esses objetos à rentabilidade dos clientes.

Para Faria e Costa (2005) o Custo para Servir tem a lógica idêntica ao método de custeio por atividades (ABC), sendo que o Custo para Servir é aplicado ao processo de Logística de distribuição.

Os estudos de Custo para Servir estão sempre relacionados à rentabilidade por cliente. Um desses estudos feitos por Kaplan (1989) mostrou que nem sempre os grandes clientes são aqueles mais lucrativos. Neste estudo, numa empresa sueca de calefação chamada Kanthal, dois dos seus maiores clientes, em volume, eram os dois dos seus clientes menos lucrativos. Este resultado sempre foi inesperado e serviu como base para tomada de decisão desta empresa, assim como no relacionamento comercial com esses clientes.

Braithwaite e Samakh (1998) realizaram um estudo onde mostram que o método do Custo para Servir não é um procedimento rígido e sim uma aproximação que pode ser aplicada em diferentes níveis. As ferramentas analíticas são construídas para refletir as circunstâncias particulares da companhia em 
termos da complexidade do negócio e as questões que têm que ser endereçadas para tomada de decisão.

Pouquíssimos trabalhos são encontrados na literatura brasileira que dizem respeito ao Custo para Servir, um deles é um estudo sobre a aplicação do método numa indústria de alimentos, elaborado por Guerreiro et al. (2008). Um dos objetivos deste trabalho foi analisar a rentabilidade de clientes, canal, família e produto, assim como sugerir ações, baseadas nestas análises, para melhorar a rentabilidade da empresa.

Para entender os custos e direcionadores da empresa analisada por Braithwaite e Samakh (1998), foi necessário coletar dados em algum detalhe e executar a análise de forma a entender quantitativamente as características da Cadeia de Suprimento. Os resultados dessas análises alimentaram o modelo do Custo para Servir. Os autores do estudo identificaram as análises normalmente feitas com esta metodologia, são elas: fluxo total de produtos por grupo de produtos ou canal; variação logística de produtos por grupo de produto ou canal; ordens e perfil de inventário; sazonalidade ou ciclicidade; suprimento; desempenho de entrega; desempenho de armazenamento; e desempenho de transportes.

Comentam ainda que a complexidade da modelagem depende das condições atuais de trabalho, do número de combinações canal/grupo de produtos e deve ser desenhada com certo nível de detalhe.

Um ponto enfatizado é que o Custo para Servir deve estar aderente ao custo total por função do negócio. Isso assegura que as taxas de rateio variáveis sejam corretamente interpretadas e o modelo estará pactuando e ligando os custos aos vários direcionadores corretamente.

Como um resultado esperado com a implantação do modelo é que as empresas estarão bem advertidas para realizar investimentos, marketing, sourcing e tomar decisões comerciais e operacionais baseados no Custo para Servir.

Atualmente, muitas empresas enfrentam problemas de controle por não apresentarem foco na gestão de custos, com isso Faria et al. (2010) sugerem analisar custos e resultados em uma perspectiva multidimensional. A análise multidimensional deve ser feita, conforme mencionado por Faria e Costa (2005), pela apuração e análise de todos os objetos, como produtos, canais de distribuição, regiões de atendimento, chegando à análise da rentabilidade do cliente. 
Faria et al. (2010) dizem ainda que, para se obter uma maior rentabilidade, é necessário que a empresa conheça suas fontes de lucro e sua estrutura de custos.

O custo de atendimento por exemplo, pode ser objeto de análise e direcionamento na forma como a empresa atua para fidelização de seus clientes.

Na Figura 07 pode-se verificar qual direção tomar quando, por exemplo, um cliente apresenta um alto custo de atendimento e um volume de vendas também alto. Neste caso, o foco desta empresa deve ser em reduzir o custo deste cliente, visto que, em termos de volume este é um cliente grande e deveria ser mantido, contudo o custo para atendê-lo deve ser reduzido, caso contrário ele passa a ser desinteressante, pois não tem uma boa rentabilidade para a empresa.

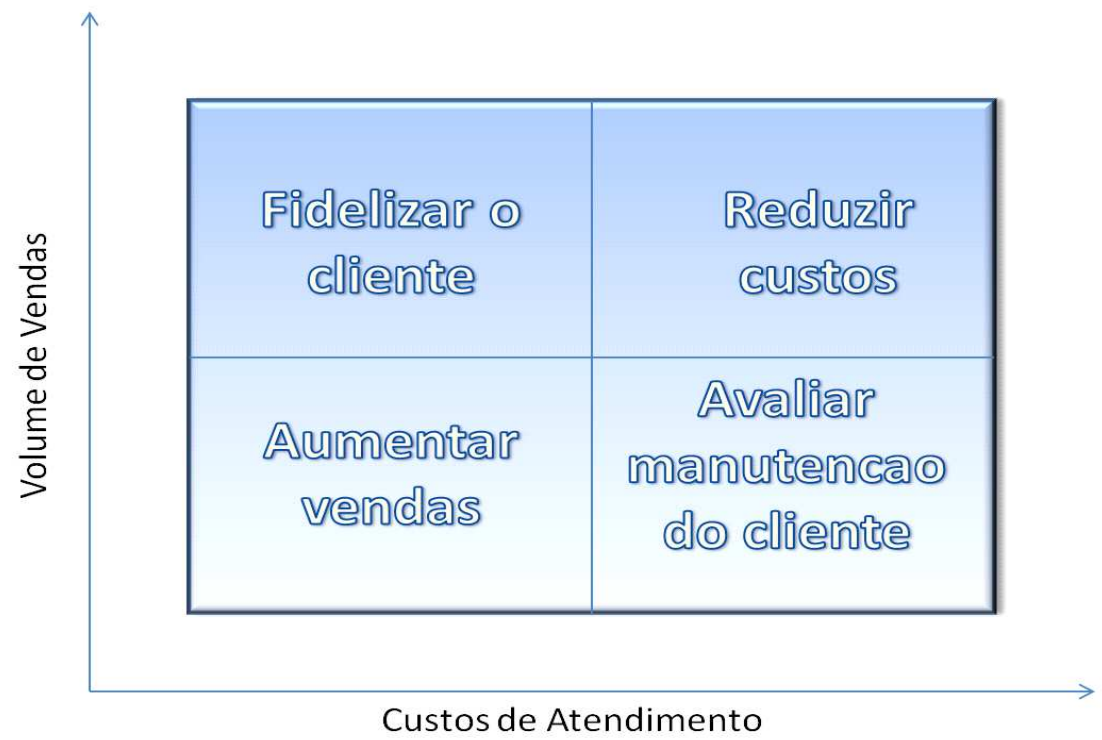

Figura 07 - Ações de acordo com Volume e Custo de Atendimento Fonte: Adaptada de Faria e Costa (2005).

São quatro direcionadores nesta análise, que correspondem ao cruzamento das informações sobre os clientes nos quesitos volume de vendas e custo de atendimento. Quando não se conhece o custo, não se foca nem se prioriza os clientes que mais geram rentabilidade para empresa. Este quadro mostra que para atuar e direcionar estrategicamente uma empresa é preciso conhecer os custos envolvidos nas operações de uma empresa.

Braitwaite e Samakh (1998) afirmam que a ferramenta de análise do Custo para Servir deve ser usada em função do momento do negócio, que o nível de sofisticação depende da necessidade levantada e da complexidade da cadeia. Outro ponto importante é definir direcionadores, princípios e premissas. 
Levantam ainda, alguns pontos os quais a análise do Custo para Servir deve compreender:
a) fluxo de produtos organizados entre os grupos de produtos por canal;
b) variedade de produtos em cada grupo de produtos por canal;
c) perfil de pedidos e de inventários;
d) sazonalidade e ciclo de demanda para tais grupos de produtos e canais;
e) suprimentos;
f) desempenho de distribuição e transporte.

Cita também os passos pelos quais deve passar a análise dos dados:

i. Evidenciar custos relativos dentro dos canais de distribuição, buscando mostrar se volumes negociados são diretamente proporcionais às receitas associadas.

ii. Segmentar clientes e receitas;

iii. Ligar custos às atividades;

iv. Evidenciar custos por família de produtos.

A ferramenta pode ser utilizada como instrumento de análise de desempenho, assim como auxiliar nas análises de trade-off de custos (trocas compensatórias entre elementos de custo). Em pesquisa realizada por Lambert e Mentzer (1980), em 300 empresas norte-americanas, apontou-se que os componentes de custo individuais não estavam disponíveis, informações necessárias para implementação destas análises citadas. Estes custos seriam por exemplo, custos de inventário, custos de armazenamento, transportes por canal, produto e cliente, custos de processamento de pedidos.

No que diz respeito às trocas compensatórias, Lambert et al. (1998) utilizam Figura 08 para ilustrar que as trocas ocorrem entre o Marketing e a Logística, onde a última deve se preocupar com os custos envolvidos nas operações que resultam no atendimento aos objetivos do marketing. 


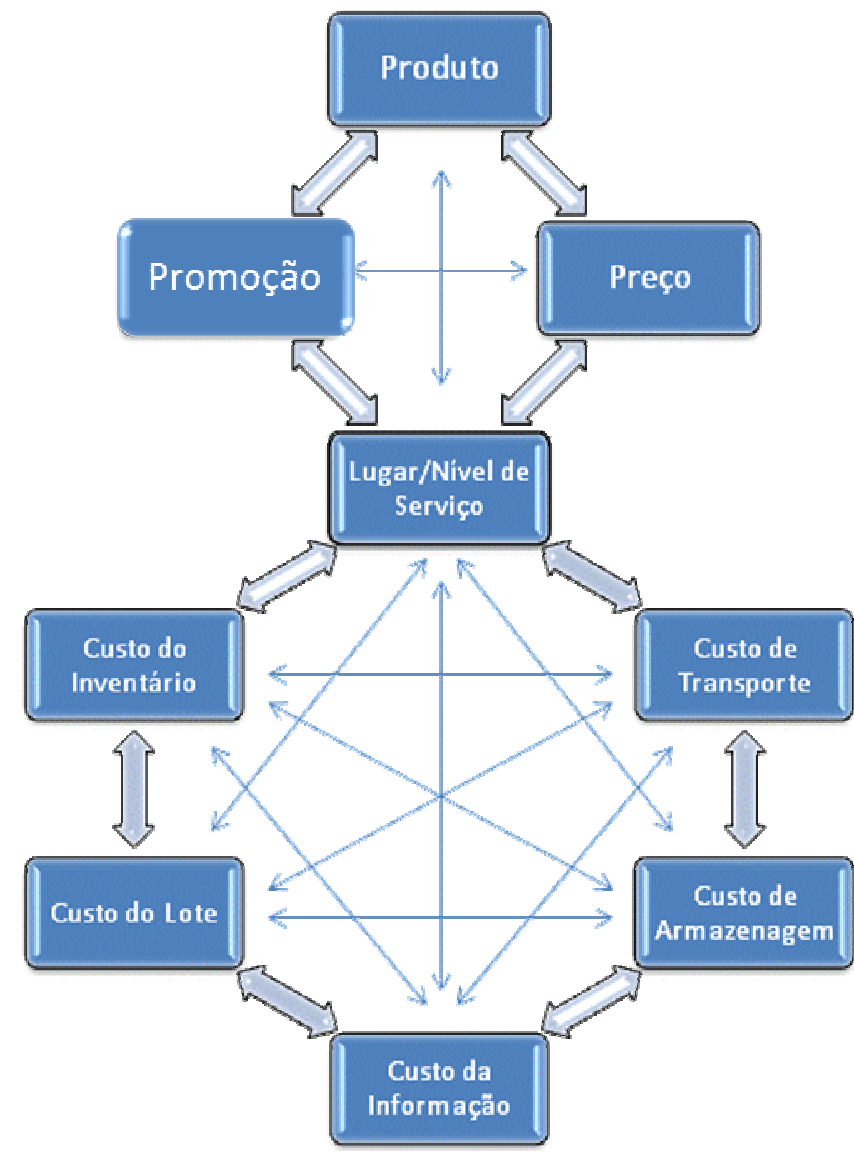

Figura 08 - Trocas compensatórias entre Marketing e Logística

Fonte: Adaptada de Lambert em "The Development of an inventory Costing Methodology" (1976).

Em relação à análise de desempenho, o próximo item deste Capítulo apresenta alguns conceitos existentes atualmente na bibliografia, assim como a possibilidade de se medir o desempenho baseado no Custo para Servir.

\section{3}

\section{Indicadores de Desempenho na Logística}

Numa pesquisa realizada por Lavalle (1995), o autor mostra que os indicadores de Custos Logísticos, numa gama de 49 outros indicadores, estão localizados em segundo lugar no que diz respeito à utilização prática para avaliação do desempenho das empresas questionadas. Nesta linha, Faria e Costa (2005) consideram que o Custeio Baseado em Atividades (ABC) é o melhor 
método para medir tais custos logísticos e citam que uma das ferramentas existentes para essa mensuração e análise de rentabilidade é o Custo para Servir.

O terceiro indicador efetivamente utilizado pelas empresas, ainda segundo pesquisa de Lavalle (1995), é o Serviço ao Cliente. O Custo para Servir é diretamente proporcional ao Nível de Serviço prestado aos clientes, pois para nível de serviço acordado, tem-se um custo associado a ele, que aumenta à medida que o nível de serviço aumenta.

Maskell (1991) afirma que as medidas de desempenho de uma empresa devem ser compreendidas em três tipos: recursos, produção e flexibilidade. 


\section{3 \\ Petrobras e Gestão de Custos}

O petróleo é uma fonte de energia cujos derivados são utilizados, por exemplo, como combustíveis nas indústrias e no transporte, o que permite afirmar que esta fonte está intimamente ligada com o crescimento de qualquer país. Atualmente, ela tem baixa substituibilidade mundialmente falando. Em 1994, Yergin já afirmava que se vive numa sociedade do hidrocarboneto, o composto químico de que o petróleo é formado.

Conforme publicado em 2011 pelo IEA (International Energy Agency), o petróleo é a maior fonte primária de energia do mundo, representando 32,80\% do total, seguido do Gás Natural com 20,90\% como se pode observar na Figura 09:

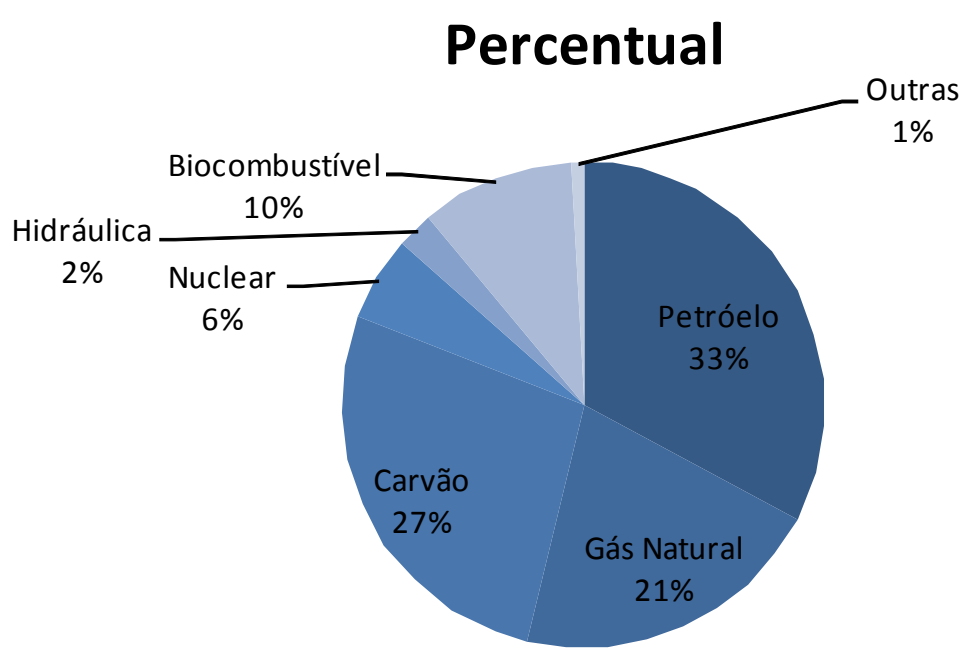

Figura 09 - Percentual de utilização de fonte de energia

Fonte: Adaptado de IEA, Key World Energy Statics (International Energy Agency, 2011).

Ainda de acordo com a publicação do IEA, transporte e indústria consumiram juntos cerca de $71 \%$ do petróleo e seus derivados comercializados em 2009 no mundo. Esses resultados demonstram numericamente a importância deste produto para o desenvolvimento mundial. 
No Brasil, de acordo com o MME (Ministério de Minas e Energia), a produção de fonte primária de energia tem o perfil um pouco diferenciado quando se compara ao perfil mundial. A matriz energética brasileira tem baixa utilização do carvão e do gás natural, compensada pela produção de energia hidráulica que é uma parcela muita mais representativa que a mundial. $\mathrm{O}$ gráfico ilustrado na Figura 10, mostra em termos percentuais o perfil da desta matriz energética.

\section{Percentual}

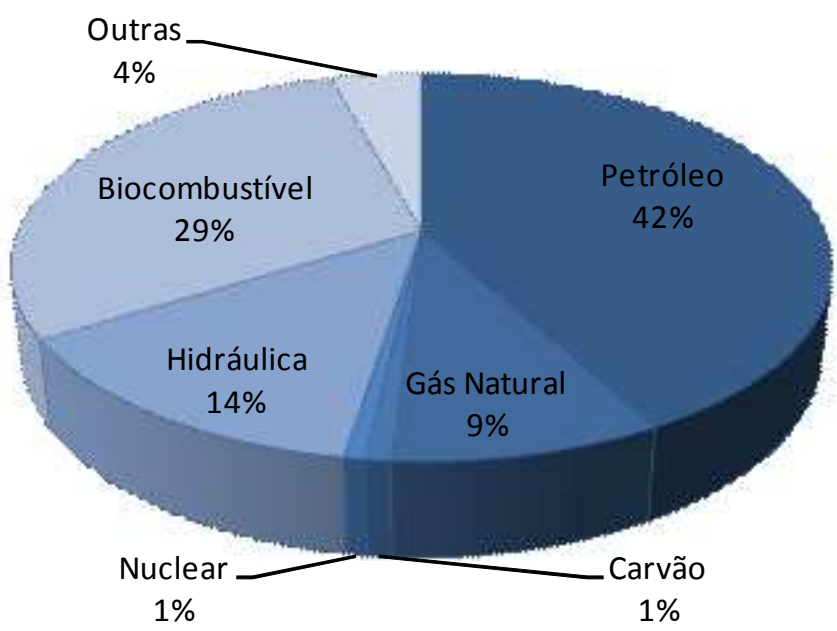

Figura 10 - Percentual de utilização de fonte de energia - Brasil

Fonte: Adaptado do MME Balanço Energético Nacional de 2011 (Ministério de Minas e Energia, 2011).

Ainda que apresentando essas diferenças nas demais fontes, o petróleo, tanto no Brasil quanto no mundo, aparece como a principal fonte primária de energia. No Brasil, o consumo final por fonte de energia se comporta historicamente conforme gráfico ilustrado na Figura 11: 


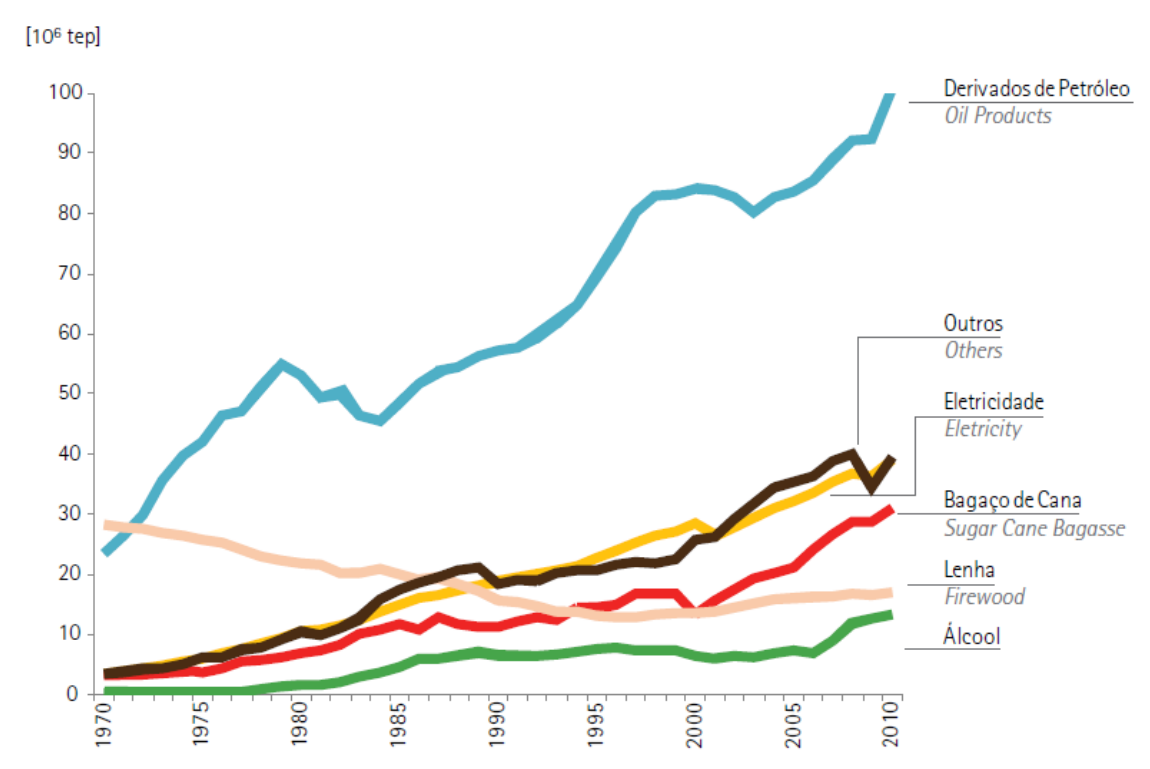

Figura 11 - Histórico de utilização de fonte de energia - Brasil

Fonte: Balanço Energético Nacional elaborado pelo MME (Ministério de Minas e Energia, 2011).

Pode-se observar que o consumo do petróleo é muito superior às demais fontes e representa cerca de $42 \%$ do total consumido no país. E este consumo vem se mostrando crescente ao longo dos anos.

A indústria do petróleo é compreendida por inúmeros processos tais como exploração, produção e refino de petróleo, processamento de gás natural, movimentação e transporte, distribuição e comercialização, assim como importação e exportação tanto de petróleo quanto de seus derivados, além do gás natural.

No período da crise do petróleo, em 1970, alguns custos da cadeia de suprimento aumentaram sensivelmente, e foi quando se deu maior importância à logística. Esses custos estão associados ao transporte, carregamento de inventário, manutenção de estoques e custos financeiros (LUKKA, 2004, p.2).

A Logística Integrada na Petrobras pode ser representada por duas diferentes cadeias: a de petróleo e a de derivados, a qual, adaptando Bowersox e Closs (2007), pode-se esquematizar da seguinte forma: 

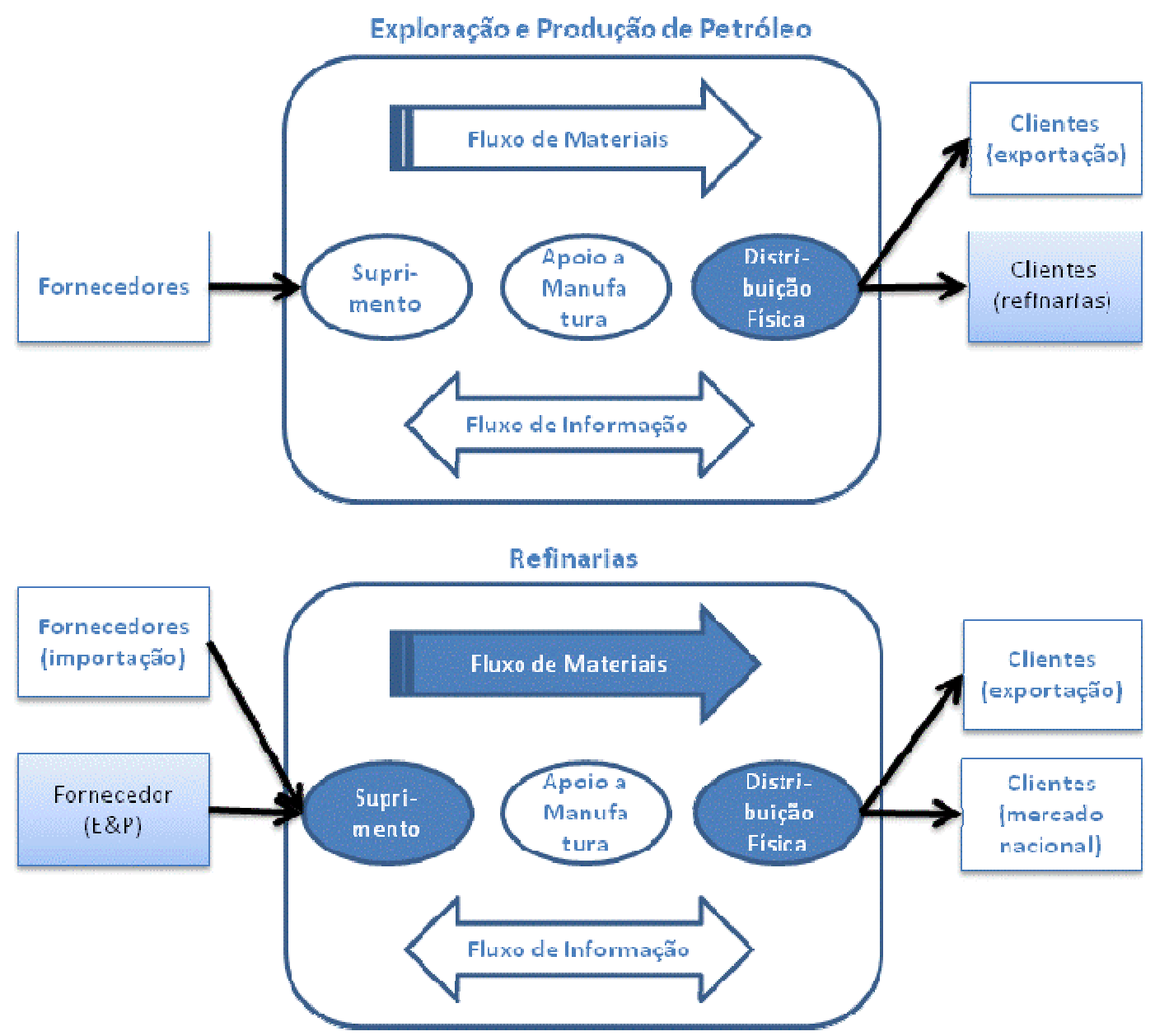

Figura 12 - Logística Integrada na Petrobras

Fonte: Adaptado de Bowersox e Closs (2007) para as cadeias da Petrobras.

A manufatura da primeira cadeia é a Exploração e Produção de Petróleo ou E\&P (Figura 12), podendo exportar o produto ou atender as demandas das refinarias. O petróleo então pode ser produto final ou matéria prima para a segunda cadeia, que é a produção de derivados feita nas refinarias. Estas refinarias estão representadas pela segunda cadeia no processo de manufatura que podem clientes do mercado nacional, assim como mercado internacional.

Na cadeia de petróleo e gás, o Upstream é parte do processo que engloba as atividades de Exploração, Perfuração e Produção do petróleo. No caso da Petrobras, o processo de transporte e armazenamento deste produto é feito pela Área de Logística do Abastecimento, uma das atividades do Downstream, além da distribuição dos derivados do petróleo, assim como refino, o marketing e a comercialização destes produtos. Os processos desempenhados pela área de Logística de Abastecimento estão representados em círculos azuis na Figura 12. 
Os custos, hoje acompanhados pela empresa de interesse deste trabalho, podem ser apresentados no gráfico da Figura 13.

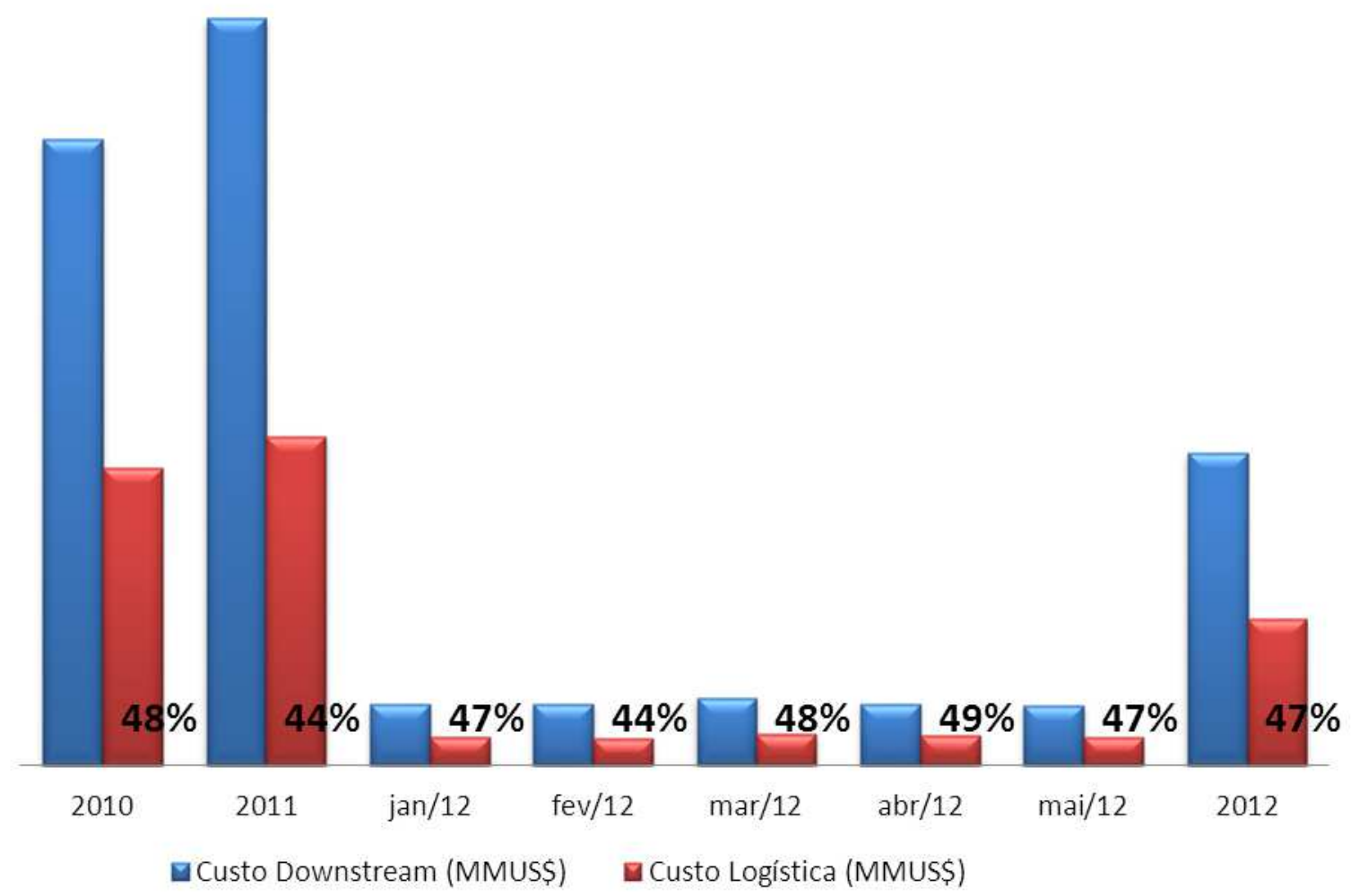

Figura 13 - Custos da Logística / Custos do Dowstream (em percentual)

Fonte: Adaptado do Sistema de Gerenciamento de Resultados da Petrobras (2012).

A barra em azul representa o custo do Downstream, que dentro da indústria do petróleo representa as ativaidades de logística, refino, marketing e comercialização dos produtos derivados. Já em vermelho, pode-se observar os custos logísticos, que giram em torno de 47\%, representando uma parcela significativa, do custo total do Downstream, mostrando a importância do tratamento detalhado destas informações em função da redução de custos.

Um custo significativo da Logística é o de transporte Marítimo, que representou, no ano de 2011 , cerca de $61 \%$ do custo total da Logística conforme pode ser observado no Figura 14. 


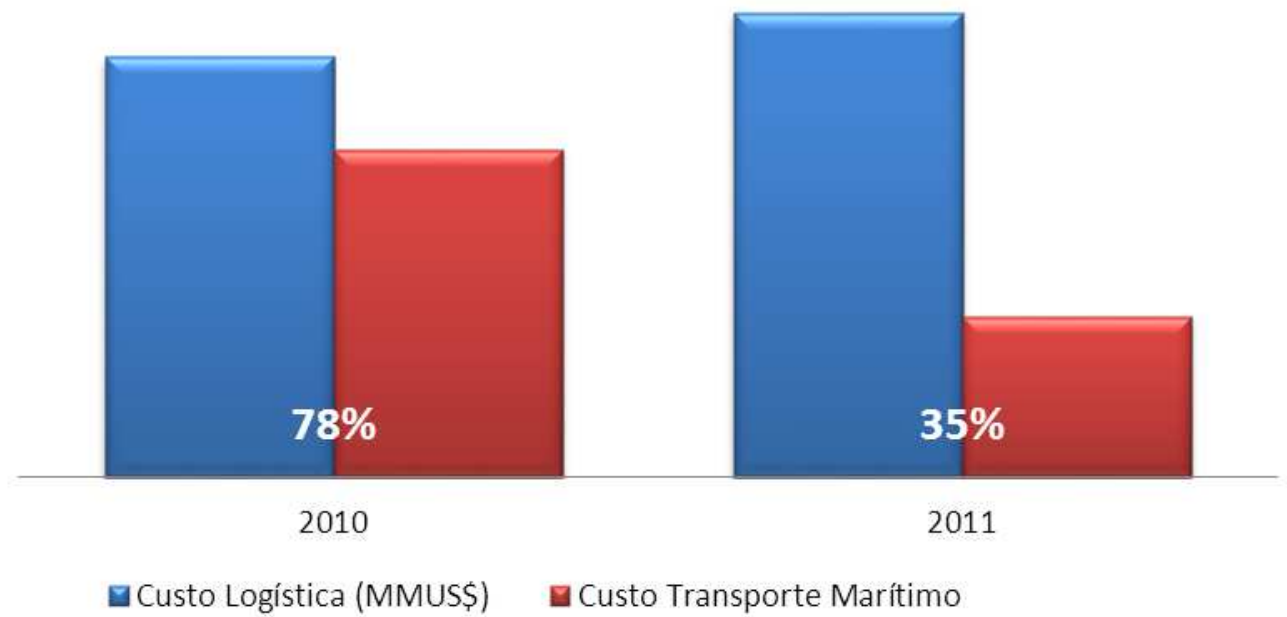

Figura 14 - Custos de Transporte Marítimo / Custo da Logística (em percentual)

Fonte: Adaptado do Sistema de Gerenciamento de Resultados da Petrobras (2012).

Sendo o custo de transporte marítimo um dos principais custos da cadeia Logística, este sim é acompanhado no detalhe dentro da empresa, contudo ele ainda não é associado diretamente ao custo de entrega para o cliente final. $\mathrm{Na}$ Figura 15 , pode-se observar que o aluguel de navios, representa $71 \%$ dos custos totais de transporte marítimo. Na Figura 15 estão representados por VCP, COA e TCP, que são tipos de contrato de aluguel.

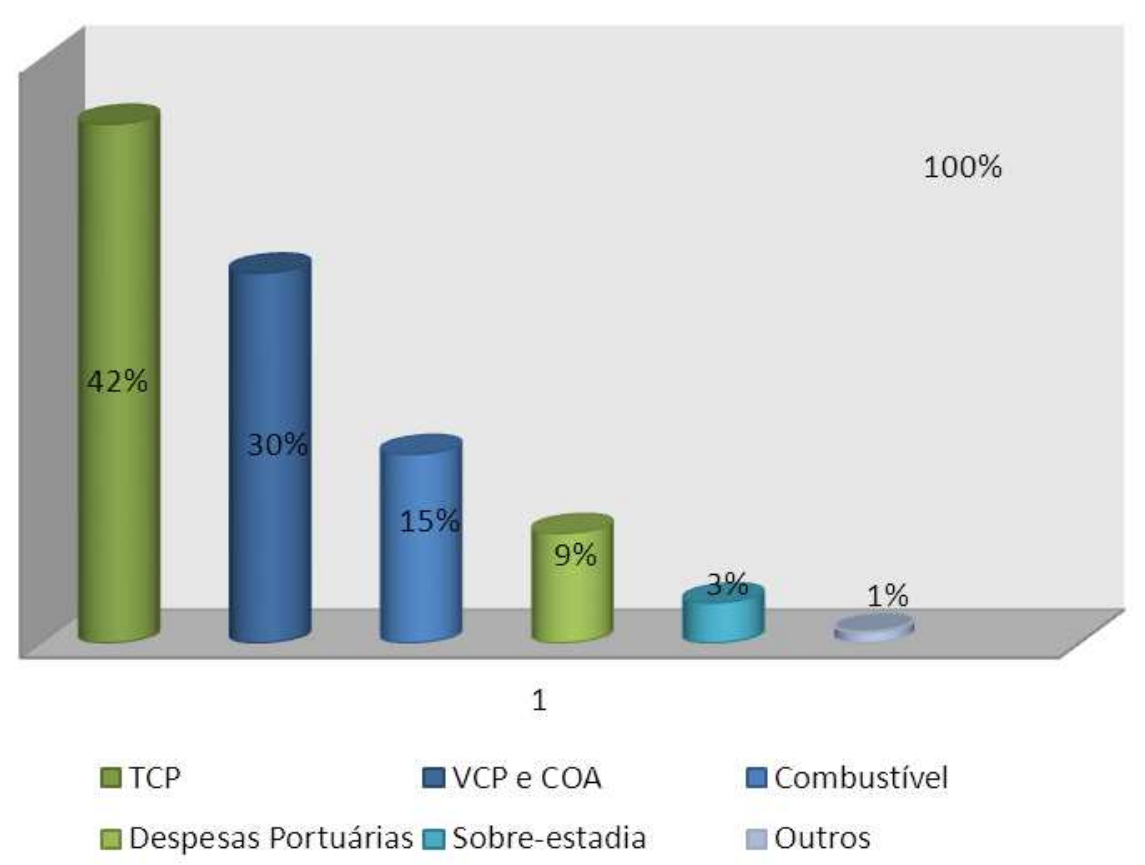

Figura 15 - Estratificação dos Custos de Transporte Marítimo

Fonte: Adaptado do Sistema de Gerenciamento de Resultados da Petrobras (2012). 
Os custos com aluguel de navios, representados no gráfico como VCP, COA e TCP somam cerca de $86 \%$ dos custos totais com o Transporte Marítimo.

Além dessa estratificação, atualmente, a Área de Abastecimento possui em seu sistema de Gestão de Resultados os seguintes indicadores relacionados a custo, com suas definições e objetivos:

a) ROCI: Realização Orçamentária de Custos de Investimentos

Definição: O ROCI mede o desvio percentual mensal e acumulado entre a realização e a previsão orçamentária.

Objetivo: Medir a realização orçamentária dos custos de investimentos previstos no Plano Anual de Negócios para permitir avaliar a eficiência do planejamento orçamentário.

b) ROCI-PD: Realização Orçamentária de Custos de Investimentos em Pesquisa e Desenvolvimento

Definição: O ROCI-PD mede o desvio percentual mensal e acumulado entre a realização e a previsão orçamentária, no caso dos investimentos em Pesquisa e Desenvolvimento.

Objetivo: Medir a realização orçamentária dos custos de investimentos em Pesquisa e Desenvolvimento previstos no Planejamento Anual para permitir avaliar a eficiência do planejamento orçamentário.

c) ROCO: Realização Orçamentária de Custos Operacionais

Definição: O ROCO mede o desvio percentual mensal e acumulado entre a realização e a previsão orçamentária dos custos operacionais.

Objetivo: Medir a realização orçamentária dos custos operacionais gerenciáveis (Materiais, Serviços de Terceiros e Encargos) previstos no Planejamento Anual, para permitir avaliar a eficiência do planejamento orçamentário.

d) ROCT: Realização Orçamentária de Custos Totais

Definição: O ROCT mede o desvio mensal e acumulado entre a realização e previsão orçamentária dos custos gerenciáveis.

Objetivo: Medir a realização orçamentária dos custos gerenciáveis previstos no Planejamento Anual, para permitir avaliar a eficiência do planejamento orçamentário.

e) CUTM: Custo Unitário de Transporte Marítimo 
Definição: Total gasto com Transporte Marítimo dividido pelo total de toneladas. Milhas produzidas (volume transportado x distância percorrida).

Objetivo: Medir o custo da tonelada milha produzida.

f) CTUD: Custo Total do Downstream

Definição: Custo Total do Downstream, deduzido os repasses de custos da área de E\&P (Exploração e Produção) e efetuadas as eliminações dos gastos entre empresas, dividido pelo volume de vendas da área no mercado interno e externo.

Objetivo: Acompanhar e monitorar os custos.

g) CDPS: Custo do Downstream I - Parcela do Segmento

Definição: Custo total da parcela do seguimento de Downstream.

Objetivo: Medir e acompanhar os Custos do Downstream na Parcela do Segmento que diz respeito ao Downstream.

h) CREF: Custo Operacional do Refino

Definição: Indica o custo unitário para o processamento de um barril de carga (petróleo + outras matérias primas) na operação de Refinação da Petrobras.

Objetivo: Avaliar e acompanhar o desempenho operacional do Refino, na dimensão custo.

i) CTDS: Custo Total do Downstream II

Definição: Somatório do custo fixo e variável por segmentos.

Objetivo: Controlar Custos.

11) Custo Total unitário da cadeia RTC

Definição: Custo Total unitário da cadeia RTC (Refino-TransporteComercialização).

Objetivo: Medir os custos da cadeira RTC (Refino-TransporteComercialização).

Os custos de realização orçamentária (ROCI, ROCI-PD, ROCO e ROCT) medem os custos realizados no período e comparam este custo com o orçamento previsto para tal atividade. Este processo de comparação não nos mostra a eficiência do processo em si, mas sim o cumprimento do orçamento previsto, sendo este alto ou baixo. Quando medidos dessa forma, não é possível otimizar o processo, pois não os custos realizados não são stratificados para que se possa visualizar a participação de cada parcela dos processos, apenas mensura-se a eficiência da área de planejamento de orçamento. 
Os outros custos (CUTM, CDPS, CTUD, CREF, CRTC) mencionados anteriormente até significam parcelas de um custo total, mas que não podem ser estratificados a ponto de uma análise visando uma melhoria dos processos operacionais. O Custo Marítimo, o Downstream, o Refino e o grupo RTC (Refino-Transporte-Comercialização), são parcelas representativas de um custo total da empresa, contudo ainda são valores com macro visão destes processos, os quais ainda necessitam maior detalhamento.

Com este quadro atual apresentado, surge a motivação para sugerir a utilização de novas ferramentas de mensuração dos custos que auxiliem na medição do desempenho e otimização de processos.

A situação problema a ser tratada neste estudo diz respeito ao fato de que na Petrobras os custos associados à entrega para os clientes não são considerados na sua totalidade e associados às atividades relacionadas à entrega. Trabalhando assim, nos momentos de tomada de decisão, estas podem estar baseadas em custos que não são reais, podendo levar a uma menor rentabilidade para o sistema como um todo.

Pode ser identificado que os custos de serviços prestados pela empresa podem ser classificados nos objetos de análise que se referem ao segmento (Abastecimento), centro de distribuição (pontos de entrega - terminais), modal de transporte (dutoviário, marítimo, terrestre, etc.) associado a rotas e clientes, caracterizando assim como uma análise multidimensional.

Kaplan e Cooper (2000) apresentam quatro estágios os quais uma empresa pode estar posicionada em relação aos seus sistemas de custeio. No Tabela 02, estão representados estes quadros. 


\begin{tabular}{|c|c|c|c|c|}
\hline Sistemas & Estágio I & Estágio II & Estágio III & Estágio IV \\
\hline Aspecto & Falhos & $\begin{array}{l}\text { Voltados para geração de } \\
\text { relatórios financeiros }\end{array}$ & Especializados & Integrados \\
\hline $\begin{array}{l}\text { Qualidade dos } \\
\text { dados }\end{array}$ & $\begin{array}{l}\text { * Muitos Erros } \\
\text { * Grandes Variações }\end{array}$ & $\begin{array}{l}\text { * Sem supresas } \\
\text { * Cumpre os padrões de } \\
\text { auditoria }\end{array}$ & $\begin{array}{l}\text { * Banco de dados } \\
\text { compartilhados } \\
\text { * Sistemas } \\
\text { independentes } \\
\text { * Vínculos informais }\end{array}$ & $\begin{array}{l}\text { * Banco de dados e } \\
\text { sistemas totalmente } \\
\text { integrados }\end{array}$ \\
\hline $\begin{array}{l}\text { Relatórios } \\
\text { financeiros e } \\
\text { externos }\end{array}$ & * Inadequados & $\begin{array}{l}\text { * Adequado às } \\
\text { necessidades de } \\
\text { geração de relatórios } \\
\text { financeiros }\end{array}$ & $\begin{array}{l}\text { * Sistema de Estágio II } \\
\text { mantido }\end{array}$ & $\begin{array}{l}\text { * Sistemas de relatórios } \\
\text { financeiros }\end{array}$ \\
\hline $\begin{array}{l}\text { Gastos com } \\
\text { produto/cliente }\end{array}$ & * Inadequados & $\begin{array}{l}\text { * Imprecisos } \\
\text { * Custos e Iucros ocultos }\end{array}$ & $\begin{array}{l}\text { *Vários sistemas } A B C \\
\text { independentes }\end{array}$ & $\begin{array}{l}\text { * Sistemas ABM } \\
\text { integrados }\end{array}$ \\
\hline $\begin{array}{l}\text { Controle } \\
\text { operacional e } \\
\text { estratégico }\end{array}$ & * Inadequados & $\begin{array}{l}\text { * Feedback limitado e } \\
\text { desatualizado }\end{array}$ & $\begin{array}{l}\text { *Vários sistemas } \\
\text { independentes de } \\
\text { avaliação de } \\
\text { desempenho }\end{array}$ & $\begin{array}{l}\text { * Sistemas de avaliação } \\
\text { de desempenho } \\
\text { estratégico e } \\
\text { operacional }\end{array}$ \\
\hline
\end{tabular}

Tabela 02 - Modelo de Quatro Estágios para projetar um sistema de custos

Fonte: Adaptado de Administre seus Custos para ser mais competitivo (Kaplan e Cooper, 2000).

Pode-se afirmar que a Petrobras se encontra em fase de implementação do

Estágio III, onde os relatórios financeiros são elaborados, contudo os sistemas de gastos com cliente/produto, controle operacional e estratégico estão em fase de implementação. Alguns sistemas ABC estão sendo implantados em diferentes áreas de atuação, assim como a medição do desempenho que é muito descentralizada e cada área tem sua forma de medição.

Os sistemas de Custeio baseado em atividades são ainda apresentados de forma experimental e em fase de estudos, não são representados em termos de indicadores e não estão presentes no sistema de Gestão de Resultados da empresa. 


\section{4 \\ Conceituação da Metodologia do Modelo do Custo para Servir e etapas de implementação}

Atualmente, a área de Logística do Abastecimento da Petrobras não possui uma ferramenta de visualização dos custos logísticos que auxilie as tomadas de decisão por parte das áreas operacionais. Assim sendo, o objetivo deste Capítulo é propor a implantação de tal ferramenta que permita calcular, exibir e analisar as informações dos custos para servir da cadeia, considerando cada movimentação e os nós logísticos a ela associados.

A proposta é apresentar uma modelagem de Custos para Servir que permita a identificação de oportunidades de melhoria contínua do desempenho econômico e operacional através:

- Da avaliação operacional dos custos logísticos alocados por atividade;

- Da avaliação horizontal dos fluxos de produto até a entrega no cliente final;

- Do suporte à tomada de decisão de áreas de interface (comercial e logística) por viés econômico.

A implantação deste modelo/ferramenta terá os seguintes benefícios:

- Conhecimento gerencial dos custos logísticos;

- Suporte à tomada de decisão de médio e longo prazo;

- Análise da base histórica dos custos;

- Visibilidade e confiabilidade em relação aos custos logísticos;

- Visão horizontal dos custos da cadeia;

- Alocação dos custos por atividade, não substituindo a contabilidade tradicional;

- Visualização dos custos mais relevantes e gerenciáveis.

Espera-se que o modelo possa auxiliar na visualização de problemas dificilmente identificáveis, como, por exemplo, a margem de bolso ou como é conhecido a pocket margin de um determinado cliente, que contribui para o 
resultado total da empresa. Quando aparentemente, no todo, o resultado é positivo, pode haver algum cliente com este resultado negativo. Neste caso, o gestor deve reavaliar a postura da empresa frente a este cliente, conforme mostrado na Figura 07.

Uma forma de se avaliar clientes com custos diferenciados, segundo Marn, Roegner e Zawada (2003), é analisando a "margem de bolso", que pode ser usada também na avaliação de produtos específicos.

A Margem de Bolso ou Pocket Margin é a margem de contribuição de cada cliente ou produto, que pode ser obtida ou visualizada através de um gráfico cachoeira como ilustrado na Figura 16:

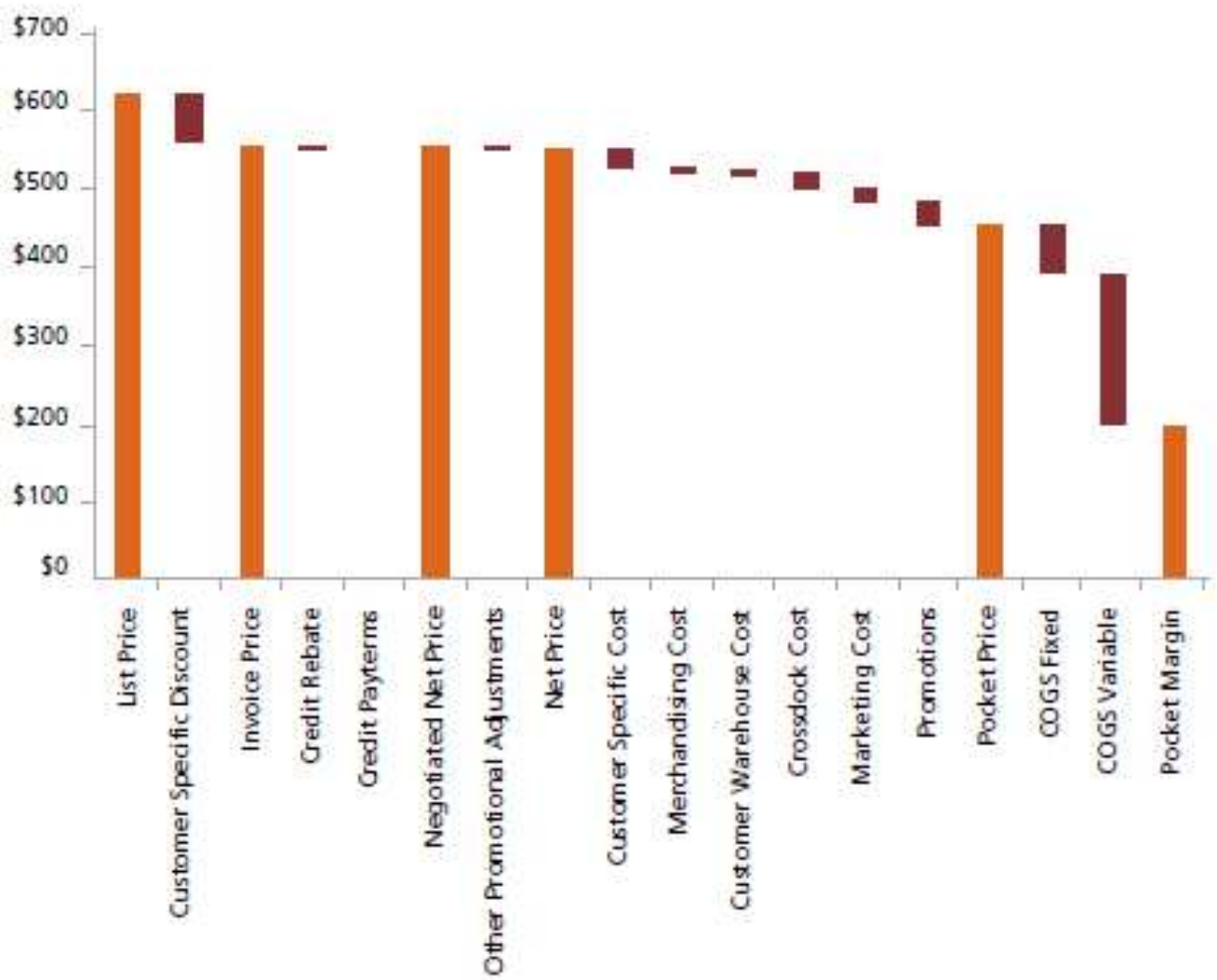

Figura 16 - Ilustração de Gráfico Cachoeira - visualização da margem de bolso através do Custo para Servir

Fonte: How profitable are your customers...really? (Johnson et al., 2009).

Segundo Johnson et al. (2009), o Custo para Servir, quando medido por transação, pode ser utilizado para obtenção da "margem de bolso". Por este motivo ela pode dar ao analista uma visão clara e mais detalhada sobre custo/margem do atendimento a clientes ou a grupos de clientes. Esses autores ainda afirmam que esta é uma forma de otimizar os ganhos da empresa. 
No Gráfico cachoeira são evidenciadas as parcelas que são deduzidas do preço de lista ou list price. Parte deles é referente aos aspectos comerciais, tais como descontos (customer specifc discount) e promoções (promotions), que, inicialmente, não serão tratados neste trabalho e outra parte refere-se ao custo do produto vendido (representado na Figura 16 como COGS - cost of goods sold ou custo do produto vendido).

Este modelo de gráfico será detalhado no capítulo5, sendo utilizado ccomo base para visualização dos resultados.

Para isso serão definidos os seguintes passos a serem seguidos para implementação de tal ferramenta:

i. Levantamento das atividades envolvidas na Logística do Abastecimento

ii. Levantamento dos possíveis direcionadores de custo para as atividades

iii. Levantamento dos possíveis objetos de custo

iv. Levantamento dos possíveis direcionadores de custo para os objetos

Após as etapas de levantamento, será apresentado um estudo de caso da implementação da ferramenta na área da Logística do Abastecimento da Petrobras.

Para facilitar o entendimento dos levantamentos, serão apresentados alguns conceitos internos a empresa e outros conceitos de análise de custo.

\section{1}

\section{Conceitos da Petrobras e de Análise de Custos}

A seguir serão apresentados os conceitos básicos referentes à própria empresa (conceitos internos e específicos), quanto aos conceitos gerais de análise de custos que serão usados para o desenho do modelo e por isso serão revistos dentro deste Capítulo. São eles:

Nós (destino ou origem) - locais onde o produto permanece durante um tempo, podendo estar aguardando uma movimentação, para processamento ou consumo; 
Arco - representa a ligação entre dois nós distintos, através do qual o produto é movimentado;

Bucket - agrupamento dos elementos de custo de uma mesma natureza;

Elemento do Bucket - cada linha de custo de uma determinada transação, que pode ser agrupado em buckets;

Bunker - combustível do navio;

Contratos Marítimos - são contratos feitos para o aluguel de navios e podem ser basicamente de três diferentes tipos:

i. Time Charter Party (TCP): contrato onde o frete é fixado pelo tempo ao qual um navio é afretado. Neste contrato o combustível fica a cargo da empresa contratante;

ii. Voyage Charter Party (VCP): contrato onde o frete é fixado por viagem para transporte de uma carga de uma origem para um destino. Neste caso a empresa contratante somente paga o frete e todos os custos são cobertos pelo contratado;

iii. Contrats of Affreightment (COA): contrato onde o frete é fixado por tonelada transportada, onde o armador realiza várias viagens a este mesmo frete. Idem ao caso anterior, o contratado arca com as despesas.

Degradação - utilização de um produto original como um segundo produto de menor valor agregado, ocasionado, principalmente, por problemas de qualidade que requerem que o produto seja utilizado como um de menor valor, ou em casos onde não há disponibilidade de produto e a venda ocorre de um produto similar mas de melhor qualidade. O produto é então degradado ou modificado em termos de informação para outro produto de menor valor.

Polo de entrega - localidade onde o produto deve ser entregue para o cliente. Podendo ser numa refinaria ou num terminal. Em geral, as entregas são comercialmente acordadas através de contratos que contêm o polo de entrega;

Remanejamento - valor que a empresa paga ao seu cliente, em função do ressarcimento da falta de produto a ser entregue ao cliente no polo de retirada contratada posteriormente. A falha é seguida de encaminhamento para retirada em outro polo, sendo pago incialmente pelo cliente, que é posteriormente ressarcido pela empresa; 
Sobreestadia - tempo que o navio fica atracado no porto além do tempo necessário para atracar, carregar e descarregar. O tempo padrão total para essas três operações é de 36 horas.

Terminal - local onde os produtos são armazenados e aguardam para serem movimentados. Então recebem produtos de um ponto ou nó e enviam para outro ponto ou nó.

Terminal Terrestre - tipo de terminal que recebe produto por modal terrestre, seja ele duto, caminhão ou trem. Armazena produtos e os envia também só por modais terrestres.

Terminal Aquaviário - tipo de terminal que pode receber produtos por modal aquaviário além dos modais terrestres de navios. São localizados na costa e possuem um porto associado a eles. Armazenam o produto e o despacham o produto por modal terrestre ou aquaviário.

Um outro conhecimento que se faz necessário é entender a cadeia da Logística do Abastecimento da Petrobras. Simplificando, ela pode ser representada de acordo com a Figura 17, onde a movimentação de produto ocorre da seguinte forma:

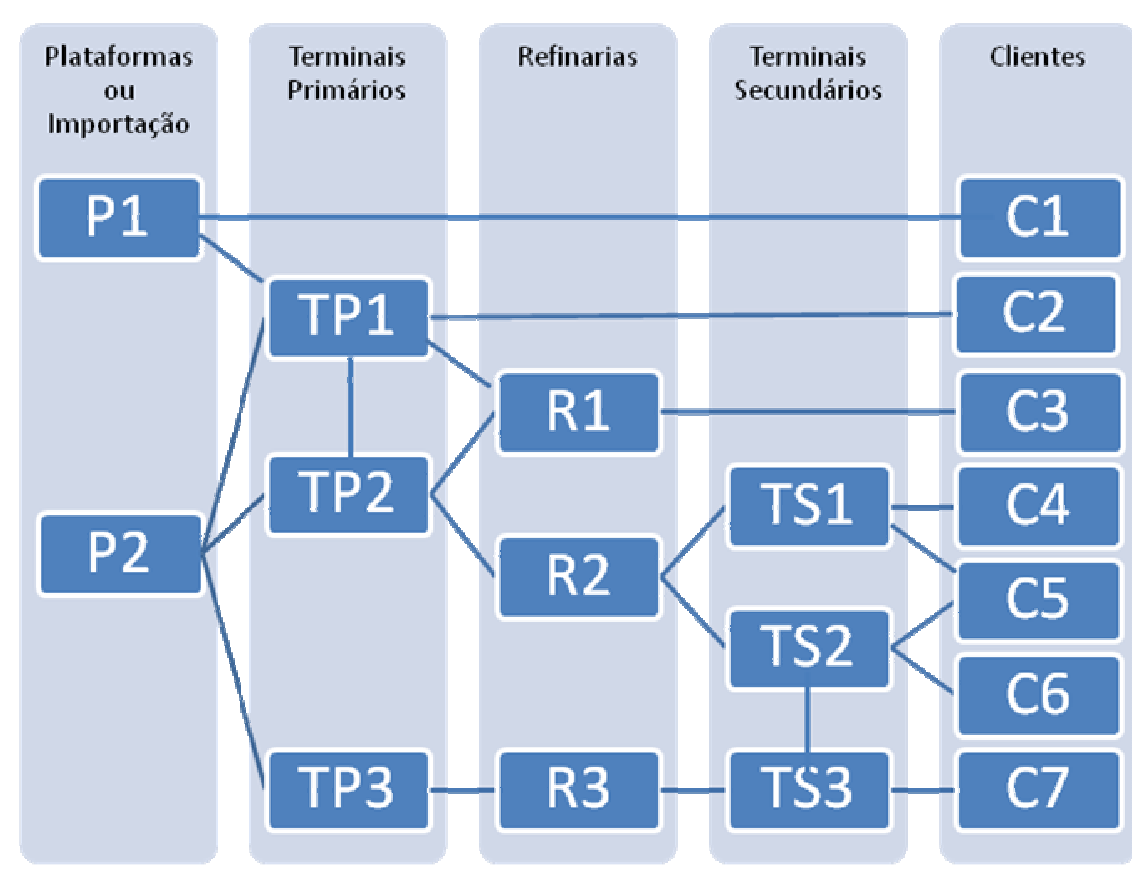

Figura 17 - Esquema simplificado da Cadeia Integrada da Petrobras Fonte: A autora (2012).

i. A matéria prima (petróleo) é produzida nas plataformas ou importada e pode seguir dois caminhos: 

a) Ser vendida diretamente a clientes;
b) Ser movimentada para terminais primários.

ii. Nos terminais primários, o petróleo pode percorrer as seguintes direções:

a) Ser vendido a clientes;

b) Ser enviado a outro terminal primário;

c) Ser movimentado para as refinarias.

iii. Nas refinarias este petróleo é transformado em seus derivados (diesel, gasolina etc.) que apresentam as possibilidades de:

a) Serem vendidos diretamente a clientes;

b) Serem enviados a um terminal secundário.

iv. Chegando aos terminais secundários, os movimentos possíveis são:

a) Vender a clientes;

b) Transferir para outro terminal secundário e assim retornar ao ponto iv.

Uma vez apresentada a cadeia integrada da Petrobras, conclui-se que cada uma das etapas tem um custo atribuído a elas. No presente estudo serão observados os custos da Logística do Abastecimento, que envolvem a movimentação e manutenção dos produtos desde sua origem (plataformas e exterior) até seu destino final (clientes finais - distribuidores de combustível). Então, para se obter o custo para servir um determinado cliente, se faz necessário apropriar corretamente os custos em cada atividade, assim como transportar estes custos desde a origem até o cliente final. Será apresentado posteriormente, no Capítulo 5, a forma como este carregamento deverá ser feito.

Esta cadeia simplificada está representada por cinco grupos de nós: plataformas ou importação, terminais primários, refinarias, terminais secundários e clientes.

Apresentados os principais conceitos, a seguir serão explicitados os levantamentos necessários para implementação do Modelo de Custo para Servir.

\section{2}

Levantamento das Atividades Envolvidas na Logística do Abastecimento da Petrobras 
As atividades da área de Logística do Abastecimento da Petrobras podem ser resumidas em movimentação e armazenamento de produto. Conforme apresentado anteriormente, esta área é responsável pela cadeia Logística da Petrobras, ou seja, pela coordenação e sequenciamento de toda a movimentação de matéria prima até a entrega de produtos finais a clientes, incluindo no meio deste trajeto os armazenamentos intermediários.

Usando a nomenclatura apresentada, existem custos associados aos nós e aos arcos. Ainda utilizando a simplificação da cadeia, tem-se os seguintes nós:
i. Plataformas
ii. Terminais Primários
iii. Refinarias
iv. Terminais Secundários
v. Clientes

As movimentações podem ser todas as ligações existentes entre os nós, ou seja:

i. Arco entre Plataformas e Clientes

ii. Arco entre Plataformas e Terminais Primários

iii. Arco entre Terminais Primários e Clientes

iv. Arco entre Terminais Primários e Refinarias

v. Arcos entre dois Terminais Primários

vi. Arcos entre Refinarias e Clientes

vii. Arcos entre Refinarias em Terminais Secundários

viii. Arcos entre Terminais Secundários e Clientes

ix. Arcos entre dois Terminais Secundários

A atividade associada a todos os arcos será resumida em movimentação de produto.

Como o foco proposto no trabalho é a área de Logística do Abastecimento, as atividades logísticas podem ser apresentadas mais detalhadamente. Desta forma, o detalhe das atividades será feito com base nas definições de nó e arco previamente apresentadas.

No que se refere aos nós, tem-se as seguintes atividades envolvidas em cada nó:

- Armazenamento de Produtos; 
- Operação \& Manutenção;

- Degradação de Produtos;

- Movimentação interna (é diferenciada das movimentações entre nós, pois ela ocorre dentro de algum nó e não no arco).

Estas atividades são específicas dos nós de terminais, podendo ser primários ou secundários. Os outros nós (plataformas, refinarias e clientes) serão desconsiderados neste primeiro momento do trabalho, pois estes custos não se referem às atividades da Área de Logística do Abastecimento e sim, à área de Exploração e Produção de Petróleo, à área de Refino e aos clientes, respectivamente.

\title{
4.3 \\ Levantamento dos Direcionadores de Custo das Atividades Envolvidas na Área de Logística do Abastecimento da Petrobras
}

\begin{abstract}
Alguns dos custos envolvidos nas atividades da Área de Logística são indiretos e precisam ser alocados a estas atividades de tal forma que sejam mais aderentes às operações. Sendo assim, serão alocados conforme o Custeio ABC e para isso precisam ser levantados os possíveis direcionadores de custo. Ressaltase que não serão esgotados neste trabalho todos os direcionadores, mas sim, aqueles que foram analisados e entendidos como mais relevantes.
\end{abstract}

\subsection{1}

\section{Direcionadores dos Nós}

Os nós relacionados às atividades da Área de Logística, como já mencionado, são referentes à Degradação, ao Armazenamento, à Operação \& Manutenção e à Movimentação.

Os custos das degradações podem ser medidos diretamente, visto que estão associados a uma quantidade e produtos específicos. Como os custos dos produtos 
são diretos, a diferença entre esses custos também é direta. Então, neste caso o direcionador é o volume degradado.

Os possíveis direcionadores de terminais que podem ser aplicados em armazenamento, operação \& manutenção e movimentação são:

- Volume armazenado: estoque médio do período dos produtos que foram armazenados naquele terminal num certo período.

- Volume movimentado: soma do volume que entrou no terminal (admitindo que todo ele saiu), reflete o total de um produto movimentado no terminal.

- Tipo de produto armazenado: alguns produtos precisam ser armazenados em alta ou baixa temperatura, demandando mais energia que os outros que são estocados em temperatura ambiente.

- Tempo de utilização de tancagem: tempo necessário de permanência do produto em tanque para que este possa se adequar à qualidade requerida antes de ser enviado ao cliente, ou até que seja determinado seu destino.

- Aspectos de qualidade: cada tipo de produto possui, por exemplo, aspectos de qualidade como viscosidade ou corrosividade. No caso da viscosidade, o produto pode requerer mais ou menos energia na hora do bombeamento. Em relação a corrosividade, este produto pode acarretar em maior necessidade de manutenção dos equipamentos.

No caso de terminais aquaviários ainda podem haver outros direcionadores, tais como:

- Tipo de Navio: cada tipo de navio requer mais ou menos atividades no porto. Além de envolver mais ou menos trabalhadores.

- Volume carregado/descarregado: dependendo do volume há maior ou menor utilização dos equipamentos envolvidos na carga ou descarga de produtos.

- Número de Navios Operados: alguns custos em terminair aqualviários são independetes do volume carregado ou 
descarregado. O que importa é o tipo de operação que é feita e que é comum a qualquer navio. Então, para estes custos o número de navios é mais importante que o volume.

Além disso, todas as combinações entre direcionadores também são possíveis direcionadores, como por exemplo, a multiplicação entre o número de navios e o volume carregado ou descarregado.

\subsection{2 \\ Direcionadores dos Arcos ou Movimentação}

No caso da Área Logística do Abastecimento da Petrobras, a movimentação é, na grande parte dos casos, feita por terceiros e os custos destas movimentações podem ser pagos de três formas: através de tarifas ou de aluguel de modais de transporte.

Para as tarifas os custos são diretos, visto que são custos unitários por modal e por tipo de produto transportado. Este é o caso, por exemplo, das movimentações que são feitas através de dutos. Para cada trecho de duto, a distância é fixa, então é estabelecida uma taxa por volume movimentado para cada tipo de produto. Assim, o direcionador é o volume. Este é considerado um custo direto e é diretamente alocado por volume.

Quando menciona-se aluguéis de modais, que são os casos de aluguel de navios, este custo é indireto e é necessário admitir direcionadores. Como já apresentados, os contratos podem ser por tempo ou por viagem, que são os dois principais tipos e para ambos os tipos de contrato, os possíveis direcionadores e a justificativa de utilizá-los são:

- Distância Percorrida: um mesmo carregamento de navio pode ser programado, por exemplo, para realizar descargas intermediárias até a chegada ao último destino. Sendo assim, cada ponto de descarga deve ter alocado em seus custos uma maior ou menor parcela dependendo da distância da origem até o ponto de descarga;

- Tempo de Viagem: o tempo utilizado para cada operação pode impactar mais ou menos nos custos da movimentação, por exemplo, se o navio navegar mais rápido, ele desgasta mais seus 
motores, gasta mais combustível, etc. Em contrapartida, existem os casos onde a movimentação pode ser mais lenta, gerando menos desgaste e consumindo menos combustível, mas ocupando mais o tempo do navio que poderia estar disponível para outra operação. Os desgastes de motores atualmente não são medidos de forma que se possa atribuir a velocidade do navio. $\mathrm{O}$ consumo de combustível, este sim pode ser estimado;

- Volume Movimentado: para um mesmo custo de um determinado aluguel de navio, quanto mais volume movimentado, menor o custo uitário do seu transporte. Cada navio tem uma capacidade volumétrica, tal que pode ser usada por completa ou parcialmente. Assim, o navio pode ter custos unitários diferenciados por utilizar mais ou menos dessa capacidade;

- Tipo de Produto: existem produtos com requisitos especiais para serem transportados, por isso, estes devem ser mais penalizados no sentido da alocação dos custos totais. Estes requisitos podem ser, por exemplo, a necessidade de aquecimento ou resfriamento do produto;

- Ou a combinação de todas anteriores, como a utilização de um direcionador que seja o produto da multiplicação entre o volume e o tempo de viagem.

Dentro das possibilidades levantadas deverá ser escolhido incialmente um direcionador, sendo ele combinado ou não, para que os custos das atividades possam ser calculados.

Após o cálculo por atividades, o Custo para Servir pode ser alcançado através dos objetos de análise que também devem ser escolhidos de acordo com a necessidade de análise.

\section{4} Levantamento dos Objetos de Análise do Custo para Servir

Os possíveis objetos de custo dentro de uma cadeia de Logística numa empresa como a Petrobras são: 
- Cliente

- Produtos

- Rota

- Localidade de Polos de Vendas

- Tipo de Modal

Para todos os objetos, pode-se calcular a rentabilidade de cada um deles, além de auxiliar na análise para tomada de decisões comerciais, operacionais, entre outros benefícios já mencionados no Capítulo 2 .

Para todos os objetos de análise do custo para servir, o direcionador pode ser o volume, podendo ser este volume movimentado, armazenado e todas as atividades que já foram citadas anteriormente.

Para se obter o custo para servir é necessário que os custos sejam carregados desde o início da cadeia, seja ela de petróleo ou de derivados. 
5

Aplicação da Modelagem de Custos na Logística do Abastecimento da Petrobras

Para a aplicação de modelagem, primeiramente serão definidos os direcionadores de acordo com uma hierarquização proposta para agrupamento dos custos.

As métricas para o cálculo dos custos, que servem como base para o cálculo dos resultados dos elementos de cada bucket, são hierarquizadas segundo Figura 18:

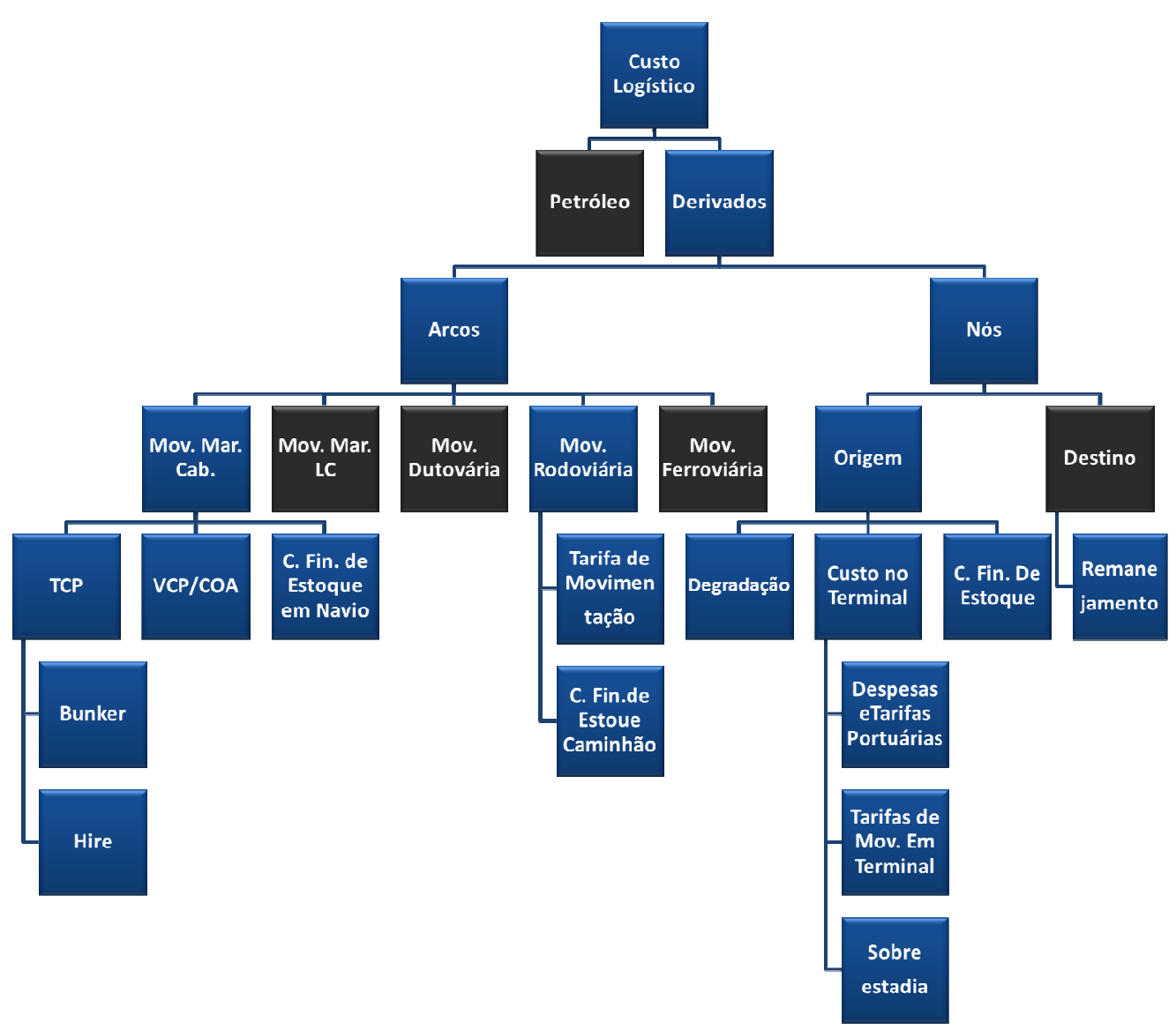

Figura 18 - Hierarquia dos Elementos de Custos por buckets Fonte: A autora (2012). 
Algumas simplificações foram feitas na Figura apresentada no sentido de minimizar seu tamanho e a tornar apresentável na tela. Então, as caixas na cor preta tiveram seus desdobramentos ocultados, pois são similares a outros apresentados. No caso de petróleo, seu desdobramento é igual à cadeia de derivados. Para Mov. Mar. LC, que quer dizer Movimentação Marítima de Longo Curso, o detalhamento é idêntico à caixa Mov. Mar. Cab., que são as movimentações de Cabotagem (transferência entre pontos operacionais na costa brasileira). Outra caixa com similaridade é a Destino que possui os elementos iguais aos da Origem. Os custos que dizem respeito às movimentações Dutoviárias, Rodoviárias e Ferroviárias são similares, visto que todas elas possuem uma tarifa e o custo do estoque em trânsito correspondente ao modal citado.

Verifica-se que os custos logísticos são estratificados em duas cadeias: a cadeia de petróleo e a derivados. Ambas as cadeias podem ser divididas em nós e arcos. Os arcos são os meios pelos quais o produto é movimentado dentro da cadeia, podendo ser pelo modal rodoviário, ferroviário, dutoviário e marítimo, este último se subdivide em dois tipos de movimento: longo curso e cabotagem. $\mathrm{Na}$ prática, os custos de modais ferroviários, rodoviários, não contribuem de forma significativa, eles representam cerca de $1 \%$ do total contratado de aluguel de transporte da empresa, por isso serão desprezados num primeiro momento de análise.

Movimentações de longo curso são aquelas referentes à exportação ou importação de produtos enquanto que cabotagem são aquelas de transferência de produto no Brasil. Essas movimentações são estratificadas por tipo de contrato do navio, visto que quando contrata-se a modalidade TCP além do próprio custo do aluguel, o contratante também é responsável pelos custos de bunker. Ainda dentro das movimentações, existe o custo financeiro do estoque em navio, que está em trânsito e o custo associado a este estoque, que não pode ser imediatamente entregue, deve ser contabilizado nos custos logísticos. Este custo financeiro é similar ao custo de estoque dos outros modais e ao custo de estoque em terminais, que estão em tanques e são considerados nos nós de destino ou de origem. Outros dois custos associados aos nós são o de degradação e o custo nos terminais. $\mathrm{O}$ primeiro diz respeito ao custo embutido no produto que é transformado num outro produto de menor valor agregado, enquanto que o segundo se refere às 
movimentações nos terminais, podendo ser cargas, descargas de navios, assim como movimentações entre tanques e de manutenção do terminal, que pode ser aquaviário ou terrestre. São consideradas também as despesas e tarifas portuárias, assim como a sobreestadia de navios contratados em VCP.

\section{1}

\section{Alocação Por Atividade}

Para cada um dos custos, um direcionador será escolhido de acordo com alguns critérios que serão descritos a seguir:

\section{Custos de Movimentação Marítima}

Para custos de movimentação marítima (cabotagem ou longo curso) tem-se os custos contábeis por navios, então estes podem ser estratificados em dois tipos: VCP/COA e TCP.

\subsection{Custos dos Contratos em VCP/COA}

Para VCP/COA o navio é contratado para uma viagem. O preço do contrato leva em consideração o volume e a distância que será percorrida. A velocidade sempre é constante neste tipo de contrato. Então, existem alguns custos extras que podem ser envolvidos nesta viagem que não estão embutidos no valor inicial do contrato, são eles: bunker extra e sobreestadia. Estes custos acontecem quando há necessidade de antecipação de uma entrega, assim a empresa solicita o aumento de velocidade e, com isso, há maior consumo de bunker, que é pago pela empresa contratante.

A sobreestadia acontece quando há, por exemplo, uma fila de espera no carregamento ou descarregamento de produtos, o custo deste tempo extra que o navio fica esperando também é por conta da empresa contratante. Contudo, este custo é alocado no terminal ao qual este incorreu, enquanto que o combustível extra é alocado, em termos de custos gerenciais, no custo do VCP.

Então observa-se os seguintes custos unitários e seus direcionadores escolhidos: 
a) Contrato: Como o contrato é negociado de acordo com as quantidades e distâncias envolvidas em cada viagem, o custo de cada navio contratado deve ser direcionado pela combinação distância x volume. Então, o custo unitário será dado pelo somatório dos custos de navios contratados em VCP divididos pelo somatório da combinação volume $\mathrm{x}$ distância das viagens realizadas pelos navios em VCP, conforme segue:

$$
\text { Custo do Controto } \left.=\frac{\sum_{i=1}^{n} \text { Custo de Novios VCP ou COA } A_{i}}{\sum_{j=1}^{v}\left(\text { Volume }_{j} x\right. \text { Distancia }}\right)
$$

Onde,

$\mathrm{n}=$ número de contratos de Navios $\mathrm{VCP}$ ou COA no período analisado e,

$\mathrm{v}=$ número de viagens de Navios $\mathrm{VCP}$ ou COA no período analisado

Unidade de Medida: \$/ton. Milha

b) Bunker: Este é um custo além do custo do contrato e deverá ser direcionado pela combinação de três direcionadores, são eles: distância dividida pelo tempo, resultando na velocidade do navio multiplicado pelo volume transportado. O consumo de combustível varia de acordo com a variação destes três componentes. Assim, tem-se:

$$
\text { Custo do Bunker VCP ou COA }=\frac{\sum_{i=1}^{n} \text { Custo de Bunker Extra }}{\sum_{i=1}^{n}\left(\frac{\text { Distância }}{\text { Tempo }} x \text { Volume }\right)_{i}}
$$

Onde,

$\mathrm{n}=$ número de viagens de Navios $\mathrm{VCP}$ ou COA que utilizaram bunker extra no período analisado

Unidade de Medida: \$.h/ton. Milha

Então,

Custos dos Contrutos em VCP OL COA

$$
=\text { Custo do Contrato + Custo do Bunker VCP ou COA }
$$

\subsection{Custos dos Aluguéis em TCP}


No tipo de contrato TCP o aluguel é pago para utilização do navio por um tempo determinado. Neste tempo, o navio é tratado como um ativo da própria empresa, sendo a contratante responsável pelo custo do combustível e este navio é utilizado conforme orientações das áreas de programação de navios. O custo do aluguel deverá ser proporcional ao tempo que aquele volume ocupou de uma viagem daquele navio. Sendo assim, deverá ser uma combinação de tempo e volume conforme segue:

a) Custo do Aluguel em TCP:

Custo do TCP $=\frac{\sum_{i=1}^{n} A_{i}}{\sum_{i=1}^{n} H_{i}}$

Onde,

$\mathrm{n}=$ número de navios alugados em TCP

$\mathrm{A}=$ custo anual do aluguel de navio em TCP

$\mathrm{H}=$ horas totais disponíveis dos navios

Unidade de Medida: $\$ / \mathrm{h}$

Neste caso o tempo será direcionado pelo volume movimentado por cada navio/produto.

b) Custo do Bunker dos navios em TCP

Este é um custo além do custo do contrato e é proporcional ao tempo e ao volume movimentado utilizado. Da mesma forma que o custo do contrato TCP, este custo será direcionado da seguinte forma:

Custo o Bunker $T C P=\frac{\sum_{i=1}^{n} B_{i}}{\sum_{i=1}^{n} H_{i}}(5)$

Onde,

$\mathrm{n}=$ número de navios alugados em TCP

$\mathrm{B}=$ custo anual do bunker dos navios em TCP

$\mathrm{H}=$ horas totais disponíveis dos navios em TCP

Unidade de Medida: $\$ / \mathrm{h}$

Neste caso o tempo será direcionado pelo volume movimentado por cada navio/produto. 
Então,

Custos dos Ahguéis em TCP = Custo TCP + Custo do Bunker TCP (6)

\subsection{Custos de Estoques em Navio}

Além dos custos por navio, existe o custo de estoque em trânsito, que é um custo financeiro do produto armazenado (temporariamente) que, em geral, compreende os custos de operação \& manutenção, e pode ser obtido diretamente através do seu custo unitário:

Custo Financerro de Estoque em Navio $=\sum_{i}^{n} \frac{\text { Custo de Capital. Custo de Estoque }}{\text { Volume Movimentad } s_{n}}$

Onde, $\mathrm{n}=$ número de produtos movimentados no período analisado

Unidade de Medida: $\$ / \mathrm{m}^{3}$

Então, o custo de movimentação marítima (cabotagem ou longo curso) será:

Custo da Movimentação Maritima

$=$ Custo dos Contratos VCP ou COA + Custos dos Alugueis em TCP

+ Custo Financetro de Estoque em Navio

O custo da sobreestadia será associado posteriormente ao custo dos terminais, visto que acontecem nos casos onde há ineficiência do próprio terminal.

2. Custos de Movimentação Dutoviária

Os custos de Movimentação Dutoviária são custos diretos, pois as tarifas são cobradas de acordo com o produto e o trecho de duto utilizado.

Então, determina-se:

Custo Movimentação Dutoviária $=\sum_{i}^{n} \frac{\text { Tarifa Dutoviária } a_{n}}{\text { Volume Movimentado } o_{n}}$ Onde, 
$\mathrm{n}=$ número de tarifas por produto/trecho utilizado no período

analisado

Unidade de Medida: $\$ / \mathrm{m}^{3}$

E,

Custo Financeiro de Estoque em Dutos $=\sum_{i}^{n} \frac{\text { Custo de Copital. Custo de Estoque }}{\text { Volume Movimentadc }}$

Onde,

$\mathrm{n}=$ número de produtos movimentados em dutos no período analisado

Unidade de Medida: $\$ / \mathrm{m}^{3}$

Custo de Estoque $=$ o custo contábil de cada tipo de produto em cada localidade (terminal ou refinaria)

Sendo assim, o custo total será:

Custo Total de Movimentaçăo Dutoviária

= Custo Mowmentaçio Dutoviária

+ Custo Financeirods Estoque em Dutos

Os custos de movimentação Ferroviária e Rodoviária são similares aos custos dutoviários.

3. Custos de Movimentação Ferroviária

Custo Movimentaça Ferroviária $=\sum_{i}^{n} \frac{\text { Tarifa Ferroviária }}{\text { Volume Movimentado }_{n}}$

Onde,

$\mathrm{n}=$ número de tarifas por produto/trecho utilizado no período analisado

Unidade de Medida: $\$ / \mathrm{m}^{3}$

$\mathrm{E}$,

Custo Financeiro de Estcque em Trens $=\sum_{i}^{n} \frac{\text { Custo de Capital . Custo de Estoque }_{n}}{\text { Volume Movimentado }}$

Onde, 
$\mathrm{n}=$ número de produtos movimentados por trens no período

analisado

Unidade de Medida: $\$ / \mathrm{m}^{3}$

Sendo assim, o custo total será:

Custo Total de Movimentação Ferroviária

= Custo Movimetaçzo Ferroviária

+ Custo Financeiro de Estoque em Trens

4. Custos de Movimentação Rodoviária

Custo Movimentação Rodoviária $=\sum_{i}^{n} \frac{\text { Tarifa Rodoviária } a_{n}}{\text { Volume Movimentadon }}$

Onde,

$\mathrm{n}=$ número de tarifas por produto/trecho utilizado no período analisado

Unidade de Medida: $\$ / \mathrm{m}^{3}$

$\mathrm{E}$,

Custo Financeiro de Estoque en Camihöes $=\sum_{i}^{n} \frac{\text { Custo de Capital Custo de Estoque }_{n}}{\text { Volume Movimentado }_{n}}$

Onde,

$\mathrm{n}=$ número de produtos movimentados por caminhões no período analisado

Unidade de Medida: $\$ / \mathrm{m}^{3}$

Sendo assim, o custo total será:

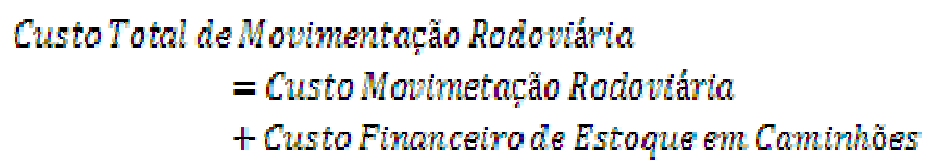

Sendo assim, todos os custos de movimentação foram explicitados. Agora, serão tratados os custos dos nós, que podem ser tanto na origem quanto no destino.

1. Custos de Degradação 
Os custos de degradação são diretamente ligados ao custo unitário do produto e são alocados pelo volume degradado:

$$
\text { Custo de Degradaça }=\sum_{i}^{n} \frac{(\text { Custo Produto } A-\text { Custo Produto } B)_{n}}{\text { Volume Degradado }}
$$

Este custo só é calculado quando o custo do produto A for de maior valor que o custo do produto B.

Onde,

$$
\mathrm{n}=\text { número de degradações ocorridas no período analisado }
$$

Unidade de Medida: $\$ / \mathrm{m}^{3}$

\section{Custos de Estoque em Terminais}

Além deste custo, existe o custo financeiro de estoque, que é similar ao custo de estoque em trânsito:

Custo Financeiro de Estoque em Terminais $=\sum_{i}^{n} \frac{\text { Custo de Copital . Custo de Estoque }}{\text { Volume Módio Estccado } 0_{n}}$

Onde,

$$
\mathrm{n}=\text { número de produtos estocados em terminal no período }
$$

analisado

Unidade de Medida: $\$ / \mathrm{m}^{3}$

3. Custos de Terminais

Os custos relacionados ao terminal podem ser subdivididos em algumas parcelas, são elas:

a) Custo de Despesas e Tarifas Portuárias

São custos relacionados aos terminais aquaviários, onde acontecem cargas e descargas de navio, são despesas e taxas relacionadas aos portos. Como estão relacionados diretamente ao volume movimentado, então este será o direcionador dos custos:

$$
\begin{aligned}
& \text { Custo de Despesas s Tanifas Portuánias } \\
& \qquad=\sum_{i}^{n} \frac{\text { Custos de Despesas e Tanifas Portuárias }_{n}}{\text { Volume Carrsgado e Descarregado }}
\end{aligned}
$$

Onde, 
$\mathrm{n}=$ número de operações de cargas/descargas nos portos no período de análise;

E o custo é dado por porto.

Unidade de Medida: $\$ / \mathrm{m}^{3}$

b) Custos Em Terminal (tarifas de movimentação)

Este custo se refere ao volume movimentado e armazenado dentro do terminal, assim como os custos de manutenção \& operação. Este custo contempla, por exemplo, deslocamentos de produto entre tanques, cargas e descargas de navio (relacionado às atividades no terminal). Da mesma forma que os custos de despesas portuárias, o volume movimentado será o direcionador neste caso também:

Custo de Movimentação nos Terminais $=\sum_{i}^{n} \frac{\text { Tarifade Movimentaçáo no terminal }}{\text { Volume Movimentadc }}$

Onde,

$\mathrm{n}=$ número de produtos movimentados no terminal no período de análise;

E o tarifa é dada por terminal.

Unidade de Medida: $\$ / \mathrm{m}^{3}$

c) Custos de Sobreestadia

Como já mencionado, o custo da sobreestadia será contemplado no terminal e é um custo pago ao fornecedor, já referenciado em contrato, de acordo com as horas em excesso:

Custo de Sobrestadia $=\sum_{i}^{n} \frac{\text { Custo de Sobrestadia }_{n}}{\text { Horas em Excesson }}$

Onde,

$\mathrm{n}=$ número de operações que tiverem excesso de estadia quando comparada com o tempo padrão no período de análise

Unidade de Medida: $\$ / \mathrm{h}$ 
Custods Terminais

= Custo de Tanifas o Despesas Portuknias + Custo m Terminas

+ Custo de Sobrestudio

4. Custos de Remanejamento

Ainda nos nós que são pontos de vendas existe o custo de remanejamento, conforme segue:

$$
\text { Custo de Remanejamento }=\sum_{i}^{n} \frac{\text { Custo de Remanejomento }}{\text { Volume Remonejado }}
$$

Onde,

$\mathrm{n}=$ número de operações de remanejamento padrão no período de análise

Unidade de Medida: $\$ / \mathrm{m}^{3}$

\section{2 \\ Visualização dos Custos por Atividade Numa Ferramenta de Análise}

A ferramenta de visualização deve exibir os custos detalhados arco a arco através de um gráfico tipo cachoeira (cascata). Este tipo de gráfico mostra as parcelas de um valor que, neste caso, é o custo de um produto desde uma origem a um destino qualquer, a depender da escolha do próprio analista. Esta análise é pontual e deverá ser usada quando for necessário o detalhamento de um determinado desvio (operacional ou financeiro) encontrado em um dos arcos, ou como subsídio de uma análise de viabilidade econômica de uma movimentação que envolve os dois nós.

Para este tipo de detalhamento, os elementos de custo deverão ser agrupados em três níveis:

a) O primeiro nível identifica onde o custo é incorrido, podendo ser no Nó de origem, no arco de movimentação logística (ou perna logística) ou no Nó de Destino;

b) O segundo nível identifica o tipo do Bucket: o agrupamento dos elementos de custo que será detalhado posteriormente. Alguns exemplos de buckets são: Degradação nos Nós de Origem, Custos nos Terminais e Plataformas de Origem; 
c) O terceiro nível identifica o próprio elemento de custo para um dado Bucket: é o último nível de desagregação de um custo, é uma linha de custo. Posteriormente, serão apresentados os elementos de custo que serão levados em consideração no presente trabalho.

Para cada arco analisado, deverão ser apresentados os custos envolvidos por nível, começando pelo primeiro, onde este será o resultado da soma dos buckets abaixo dele, assim como todos os cálculos e elementos que compõem o resultado final deste bucket.

As classificações dos níveis associados de arco a arco poderão se dar conforme segue:

I) Nó de origem

a) Custo de Degradação nos Nós de Origem

i) Degradações ocorridas no Nó de Origem

ii) Degradações ocorridas nos Nós Intermediários

b) Custo dos Terminais de Origem

i) Sobreestadia

ii) Despesas e Tarifas Portuárias

iii) Tarifas de Movimentação

iv) Operação e Manutenção

c) Custo Financeiro de Estoque nos Nós de Origem

i) Custo Financeiro de Estoque nos Nós de Origem

ii) Custo Financeiro de Estoque nos Nós Intermediários

II) Movimentação ou Arcos

a) Custo da Entrega Marítima Cabotagem

i) Aluguel VCP/COA Entrega Marítima Nacional

ii) Aluguel TCP Entrega Marítima Nacional

iii) Custo Financeiro de Estoque em Navios Nacional

b) Custo da Entrega Marítima Longo Curso

i) Aluguel VCP/COA Entrega Marítima Longo Curso

ii) Aluguel TCP Entrega Marítima Longo Curso

iii) Custo Financeiro de Estoque em Navios Longo Curso

c) Custo da Entrega Dutoviária

i) Tarifa de Transporte na Entrega Dutoviária

ii) Custo Financeiro de Estoque nos dutos 
d) Custo de Entrega Rodoviária

i) Tarifa de Transporte na Entrega Rodoviária

ii) Custo Financeiro de Estoque em Caminhões

e) Custo de Entrega Ferroviária

i) Tarifa de Transporte na Entrega Ferroviária

ii) Custo Financeiro de Estoque em Trens

III) Nó Destino

a) Custo de Degradação nos Nós Destino

i) Degradações ocorridas no Nó

b) Custos nos Terminais e Plataformas de Destino

i) Sobreestadia

ii) Despesas e Tarifas Portuárias

iii) Tarifas de Movimentação

iv) Operação e Manutenção

c) Custo Financeiro de Estoque nos Nós Destino

d) Custo Financeiro de Estoque nos Nós Destino

e) Custo de Remanejamento

Então o valor total agrupado, tanto do custo quanto do volume, poderá ser visualizado também através da explicitação da soma das partes dos elementos envolvidos no cálculo. Além disso, poderá também ser analisado através do custo unitário (Custo Total/Volume Total).

A Figura 19 mostra um exemplo do gráfico cachoeira, estratificado através do primeiro nível (origem, movimentação, destino). Serão apresentados os buckets (segundo nível) de cada um deles e o valor associado a eles. A partir de cada bucket, o analista terá a opção de detalhamento dos elementos (terceiro nível) que compõem cada bucket, assim como os valores associados a eles. 


\section{Custo Arco a Arco}

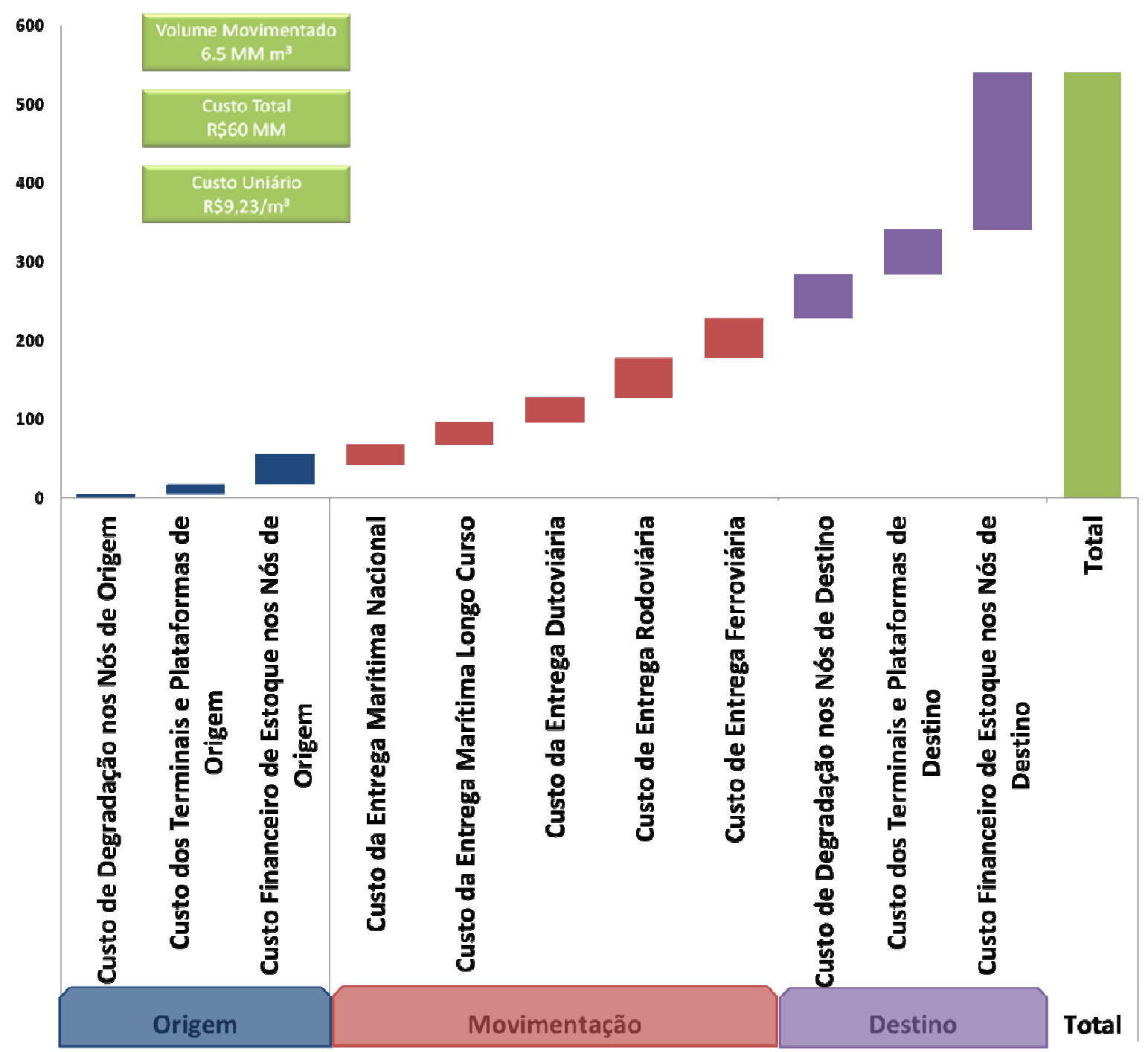

Figura 19 - Exemplo de exibição dos Buckets de custos

Fonte: A autora (2012).

A Figura 20 mostra um exemplo deste detalhamento dos Buckets, onde foi escolhido o Custo nos Terminais e Plataformas intermediários e pode-se constatar que este bucket foi composto de quatro elementos, dos quais apenas um apresentou maior relevância, representando $99,9 \%$ do resultado total do custo daquele Bucket. Este elemento foi o Despesas e Taxas Portuárias na Origem. 


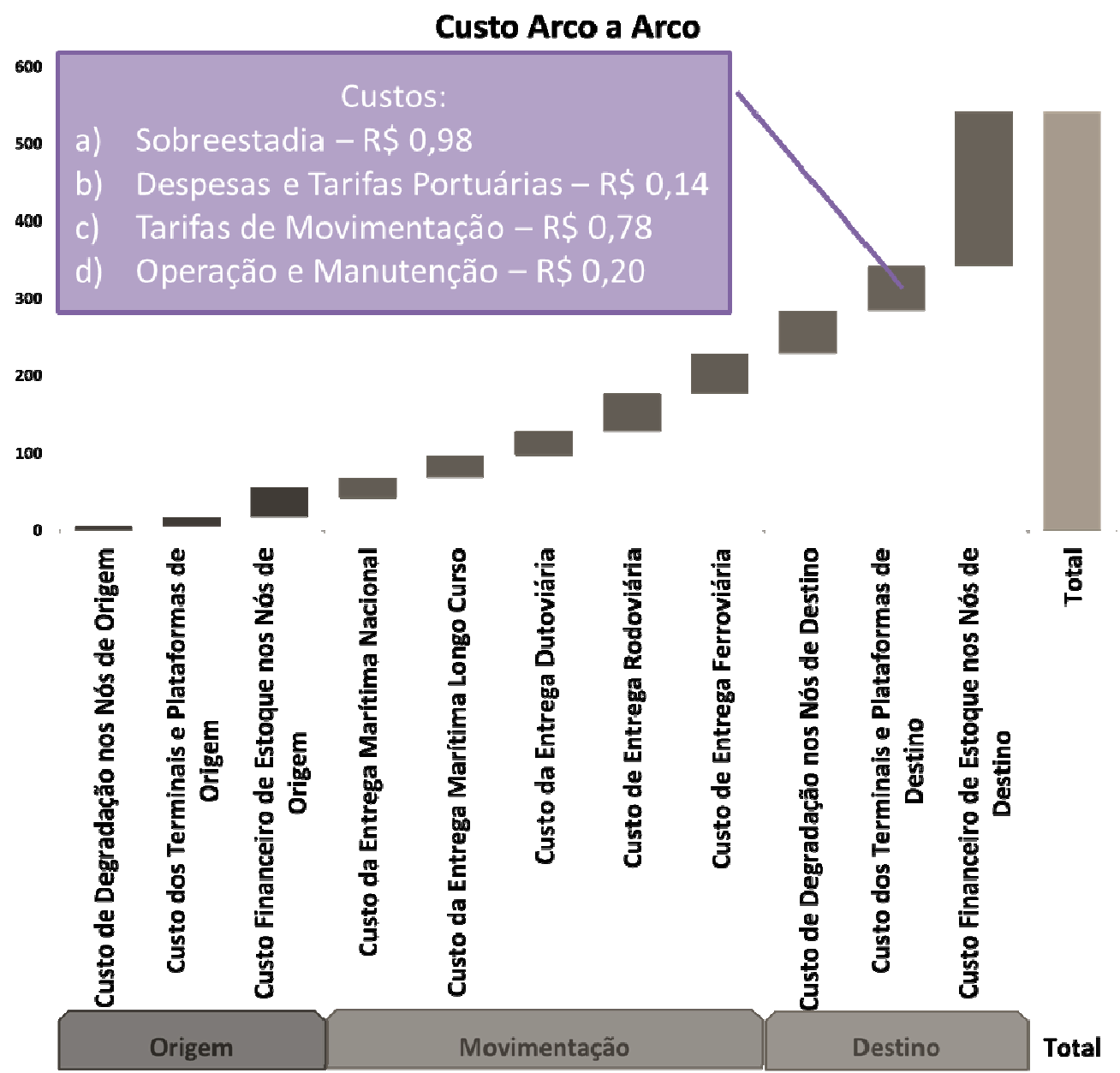

Figura 20 - Exemplo de Detalhamento dos Buckets Fonte: A autora (2012).

Para análise mais detalhada, poderão ser feitos filtros como, por exemplo, de período, produto, modal.

Desse modo, a análise dos custos arco a arco, representa os custos totais de uma origem a um destino, contemplando todos os custos associados aos nós e arcos analisados.

\section{3}

\section{Carregamento de Dados para obtenção do Custo para Servir}

As métricas apresentadas são equivalentes para os custos arco a arco e para o custo da cadeia integrada, sendo que arco a arco os resultados são totais por nó (origem ou destino) e por movimentação. No caso da cadeia integrada, os custos são alocados primeiramente por atividade e direcionados, através de driver ou direcionadores aos objetos finais de análise. Os custos de cada nó são a soma do 
seu próprio custo com os custos anteriores a ele na cadeia. Assim, sucessivamente, os custos são rateados por volume até o nó final. Para isso, se faz necessário desenvolver uma lógica de carregamento destes custos.

Simplificando o rastreamento de uma molécula de produto vendido ao cliente, pode-se afirmar que esta molécula foi oriunda de uma plataforma, passou por um terminal, seguiu para uma refinaria, onde foi transformada ou assumiu novas características, movimentou-se para outro terminal e, finalmente, foi entregue ao cliente final. Uma representação esquemática da cadeia já foi apresentada anteriormente na Figura 17 que está sendo reapresentada novamente neste Capítulo em função da necessidade de detalhamento do carregamento dos custos até o cliente final.

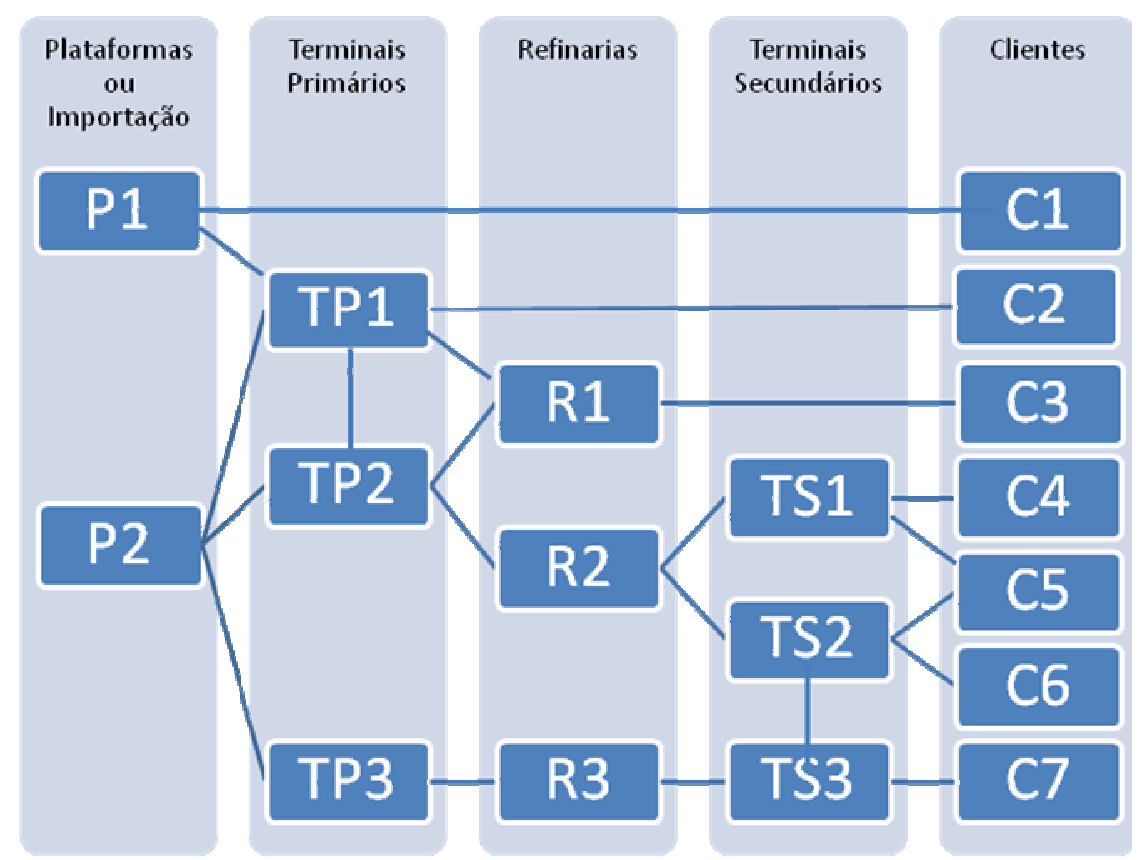

Figura 21 - Esquema simplificado da Cadeia Integrada da Petrobras Fonte: A autora (2012).

Supõe-se que o fluxo seja em um único sentido, isto é, cada nó só recebe de outro nó por um determinado tipo de movimentação tal que a inversão desta movimentação no fluxo contrário nunca acontece. Por exemplo, a Refinaria 3 (R3) somente recebe produto do Terminal Primário (TP3) e nunca envia nada para este terminal.

Como apresentado previamente nos custos arco a arco, cada um dos nós e das pernas possui um custo próprio, que também já foi detalhado. Estes custos podem ser considerados intrínsecos ao nó ou a perna. Contudo, para ter o custo da 
cadeia integrada os custos têm que ser repassados à medida que a molécula se movimenta ou se transforma ao longo da cadeia.

No exemplo da cadeia simplificada da Figura 17, o custo da entrega no cliente $\mathrm{C} 4$, visualizando da direita para esquerda (no fluxo contrário ao movimento de produtos), deve conter as seguintes parcelas:

- Custo da movimentação de TS1 para C4;

- Custo intrínseco de TS1;

- Custo da movimentação de R2 para TS1;

- Custo intrínseco de R2;

- Custo da movimentação de TP2 para R2;

- Custo intrínseco de TP2;

- Custo da movimentação de P2 para TP2 e;

- Custo intrínseco de P2.

Um ponto importante é que para um determinado nó, como por exemplo, o TS1, ele atende os clientes C4 e C5, com isso, seus custos tem que ser divididos entre esses dois clientes. Isso acontece para todos os nós, assim como para todas as movimentações que atendem mais de um cliente, podendo ser eles internos ou externos à cadeia.

Neste momento é definido um driver de custo para que esta alocação seja feita de forma ponderada. No presente estudo, da cadeia integrada da Logística de Abastecimento da Petrobras, recomenda-se utilizar o volume como driver do custo, visto que as tarifas de movimentação são cobradas por $\mathrm{m}^{3}$ movimentado, assim como os custos de degradação e de estoques, que são facilmente medidos por volume.

A seguir será apresentado um exemplo com dados fictícios do carregamento dos custos, associados às possíveis visualizações propostas anteriormente: arco a arco e cadeia integrada.

Primeiramente, serão apresentados os dados de um nó de origem, onde seus custos internos são apresentados na tabela 03: 


\begin{tabular}{|c|c|c|}
\hline \multicolumn{3}{|l|}{ Origem } \\
\hline Elementos de Custo & & $\mathrm{RSS}$ \\
\hline ARMAZENAGEM & $\mathrm{RS}$ & 270,11 \\
\hline MOVIMENTAÇÃO DE PRODUTOS & $\mathrm{RS}$ & $351.165,58$ \\
\hline MOVIMENTAÇÃO E ARMAZ. DE PRODUTOS & RȘ & $279.929,76$ \\
\hline Custo do Terminal & RȘ & $631.365,45$ \\
\hline
\end{tabular}

Tabela 03 - Dados de Custos do Local 1 (Origem) Fonte: A autora (2012).

Alguns dos produtos armazenados neste nó de origem serão movimentados em duas viagens, para dois nós de destinos distintos. Essas movimentações foram realizadas por um único navio e apresentaram os custos mostrados na tabela 04 .

\begin{tabular}{|c|c|c|}
\hline \multicolumn{3}{|c|}{ Movimentação } \\
\hline \multicolumn{3}{|c|}{ Custo Total do Navio / mês } \\
\hline Custo Aluguel TCP & $\mathrm{R} \$$ & $68.000,00$ \\
\hline Custo Bunker TCP & $\mathrm{RS}$ & $5.000,00$ \\
\hline Custo Movimentação & $\mathrm{RS}$ & $73.000,00$ \\
\hline
\end{tabular}

Tabela 04 - Dados de Custos da Movimentação Fonte: A autora (2012).

As duas viagens realizadas por este navio, terão seus custos alocados de acordo com os direcionadores propostos e são apresentados nas tabelas 05 e 06.

\begin{tabular}{|c|c|c|c|}
\hline \multicolumn{3}{|c|}{ Viagem 1} & \multirow[b]{2}{*}{ D } \\
\hline Volume $\mathrm{S} 10\left(\mathrm{~m}^{3}\right)$ & & 18.000 & \\
\hline Distância (milha) & & 6 & $\mathrm{E}$ \\
\hline Tempo Viagem (h) & & 2 & $\mathrm{~F}$ \\
\hline Custo Aluguel TCP (R\$) & $\mathrm{R} \$$ & $19.428,57$ & $(\mathrm{BxF}) /(\mathrm{F}+\mathrm{J})$ \\
\hline Custo Bunker TCP (R\$) & $\mathrm{R} \$$ & $3.214,29$ & $(D X E / F) /(G+H) \times(I / J)+(D X E / F)$ \\
\hline Custo Movimentação & $\mathrm{R} \$$ & $22.642,86$ & $x$ \\
\hline
\end{tabular}

Tabela 05 - Dados de Custos da Viagem 1 (origem - destino 1)

Fonte: A autora (2012). 


\begin{tabular}{|c|c|c|c|}
\hline \multicolumn{3}{|c|}{ Viagem 2} & \multirow[b]{2}{*}{ G } \\
\hline Volume Gasolina $\left(\mathrm{m}^{3}\right)$ & & 7.000 & \\
\hline Volume $\$ 500\left(\mathrm{~m}^{3}\right)$ & & 3.000 & H \\
\hline Distância (milha) & & 15 & 1 \\
\hline Tempo Viagem (h) & & 5 & J \\
\hline Custo Aluguel TCP (R\$̦) & $\mathrm{RS}$ & $48.571,43$ & $(\mathrm{BxJ}) /(\mathrm{F}+J)$ \\
\hline Custo Bunker TCP (R\$) & $\mathrm{R} \$$ & $1.785,71$ & $(\mathrm{G}+\mathrm{H}) \times(\mathrm{I} / \mathrm{J}) /(\mathrm{G}+\mathrm{H}) \times(\mathrm{I} / \mathrm{J})+(\mathrm{DXE} / \mathrm{F})$ \\
\hline Custo Movimentação & $\mathrm{R} \$$ & $50.357,14$ & $\mathrm{Y}$ \\
\hline
\end{tabular}

Tabela 06 - Dados de Custos da Viagem 2 (origem - destino 2) Fonte: A autora (2012).

A última coluna da direita de ambas as tabelas representa o cálculo realizado para obtenção das linhas de custos Aluguel TCP e Bunker .No caso do Aluguel, o direcionador utilizado foi o tempo total de viagem. Assim, tem-se o seguinte cálculo:

Custo Unitário do Aluguel TCP $=\frac{\text { Custo Total Aluguel TCP }}{\text { Tempo Total de Viagem }}=\frac{B}{E+J}=\frac{P \$ 68.000,00}{2+5(\text { horas })}$

Com o custo unitário, o cálculo realizado para obtenção do custo de cada viagem é feito pela multiplicação deste custo unitário pelo tempo de cada uma das viagens.

No caso do Custo do Bunker, o direcionador utilizado para alocaçào dos custos foi a velocidade (dist6ancia dividida pelo tempo) multiplicada pelo volume, assim pode-se obter o custo unitários conforme fórmula abaixo:

Custo Unitário do Bunker TCP

$$
\begin{aligned}
& =\frac{\text { Custo Total Bunker TCP }}{\frac{\text { DistânciaTotal percomida }}{\text { Tempo Total de Viogm }} \text { Volume Total Movimentodo }} \\
& =\frac{C}{\frac{(E+I) x(D+G+H)}{(F+J)}} \\
& =\frac{R 35.000,00}{\frac{6+15 \text { (mihas) }}{2+5(\text { horas })} \times 18.000+7.000+3.000\left(\mathrm{~m}^{3}\right)}
\end{aligned}
$$


Através do Custo Unitário pode-se calcular os custos de Bunker de cada uma das viagens multiplicando velocidade (distância pelo tempo) e volume.

As duas viagens foram destinadas a dois locais com seus custos apresentados nas Tabelas 07 e 08.

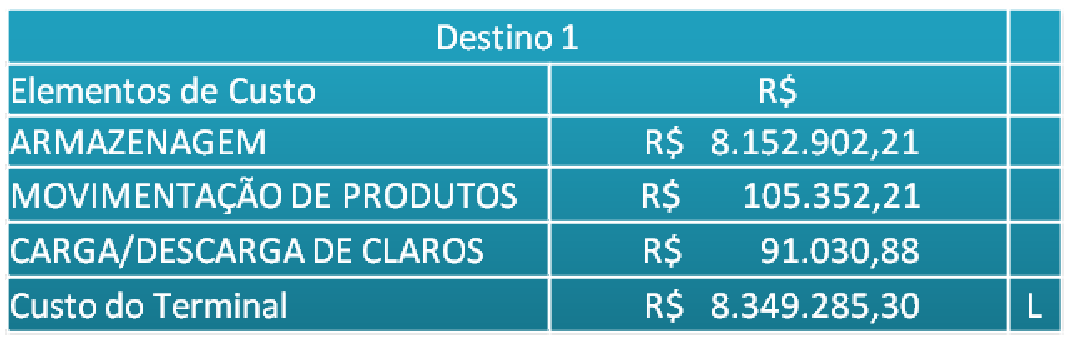

Tabela 07 - Dados de Custos do Destino 1

Fonte: A autora (2012).

\begin{tabular}{|c|c|c|c|}
\hline \multicolumn{3}{|c|}{ Destino 2} & \\
\hline Elementos de Custo & & $\mathrm{R} \$$ & \\
\hline ARMAZENAGEM & $\mathrm{R} \$$ & $7.800,25$ & \\
\hline MOVIMENTAÇÃO DE PRODUTOS & $\mathrm{R} \$$ & $1.865 .380,01$ & \\
\hline Custo do Terminal & $\mathrm{RS}$ & $1.873 .180,26$ & $\mathrm{M}$ \\
\hline
\end{tabular}

Tabela 08 - Dados de Custos do Destino 2

Fonte: A autora (2012).

Os custos destes nós de destino estão representados pelas letras L e M.

Com todos os custos levantados, estes serão carregados e apresentados de acordo com as tabelas 09 e 10.

\begin{tabular}{|c|c|c|c|}
\hline Custo Cadeia & \multicolumn{2}{|c|}{ Origem - Destino 2} & \\
\hline Nó Origem & $\mathrm{R} \$$ & $405.877,79$ & $A x D /(D+G+H)$ \\
\hline Movimentação & $\mathrm{RS}$ & $22.642,86$ & $\mathrm{Y}$ \\
\hline Nó Destino & $\mathrm{RS}$ & $8.349 .285,30$ & $\mathrm{~L}$ \\
\hline Custo Cadeia & \multicolumn{2}{|c|}{ Origem - Destino 2} & \\
\hline Nó Origem & $\mathrm{R} \$$ & $225.487,66$ & $\begin{array}{c}\mathrm{Ax}(\mathrm{G}+\mathrm{H}) /(\mathrm{D}+ \\
\mathrm{G}+\mathrm{H})\end{array}$ \\
\hline Movimentação & $\mathrm{R} \$$ & $50.357,14$ & \\
\hline Nó Destino & RS & $1.873 .180,26$ & \\
\hline
\end{tabular}

Tabela 09 - Dados de Custos Calculados da Viagem 2

Fonte: A autora (2012). 
Para o Custo da Cadeia Integrada, os custos dos nós de origem serão direcionados pelo volume movimentado para cada um dos destinos. Isso acontece, pois no exemplo citado, os únicos dois destinos para os produtos armazenados na origem foram os Destinos 1 e 2. Com isso, pode-se obter o custo unitário da origem através do cálculo da equação xx:

$$
\begin{gathered}
\text { Custo Unitário da Origem }=\frac{\text { Custo Origem }}{\text { Volume Total de Swidadn Origem }}=\frac{A}{D+G+H} \\
=\frac{R S 631.365,45}{18.000+7.000+3.000 m^{3}}
\end{gathered}
$$

Para se obter o Custo da Origem nos Destinos foi feita a multiplicação pelo volume movimentado para cada destino. Para os custos da movimentação, a alocaçào já havia sido realizada anteriormente, podendo ser replicada. Isso só é possível, pois no exemplo dado, cada viagem possui um único destino diferente.

Para a visualização Arco a Arco, os custos serão apresentados na sua totalidade e não são direcionados. Assim, os custos da origem são os mesmos para ambos os destinos, os da movimentação são as duas viagens ligadas aos destinos e os custos dos nós de desetino são seus próprios cstos. Todos estes custos podem

\begin{tabular}{|c|c|c|c|}
\hline Custo Arco Arco & \multicolumn{2}{|c|}{ Origem - Destino 1} & \\
\hline Nó Origem & $\mathrm{R} \$$ & $631.365,45$ & A \\
\hline Movimentação & $\mathrm{RS}$ & $22.642,86$ & $x$ \\
\hline Nó Destino & $\mathrm{R} \$$ & $8.349 .285,30$ & $\bar{L}$ \\
\hline Custo Arco Arco & \multicolumn{2}{|c|}{ Origem - Destino 1} & \\
\hline Nó Origem & R\$ & $631.365,45$ & A \\
\hline Movimentação & $\mathrm{RS}$ & $50.357,14$ & $\bar{Y}$ \\
\hline Nó Destino & $\mathrm{RS}$ & $1.873 .180,26$ & $\bar{M}$ \\
\hline
\end{tabular}
ser visualizados na tabela 10 .

Tabela 10 - Dados de Custos Arco a Arco (exemplo prático) Fonte: A autora (2012).

A seguir serão apresentadas as formas gráficas de visualização destas informações. 


\section{4}

\section{Visualização do Custo da Cadeia Integrada Numa Ferramenta de Análise}

De forma semelhante ao custo arco a arco, as informações de custo de cadeia integrada serão agrupadas em três níveis. O primeiro nível identificará o grupo de custo (grupo de buckets), o segundo nível identificará o tipo do bucket, já o terceiro, este exibirá os elementos de cada bucket. As classificações dos níveis serão associadas às movimentações, conforme apresentado na Tabela 03:

\begin{tabular}{|c|c|c|}
\hline $1^{0 .}$ Nível & $2^{\text {o. Nivel }}$ & $3^{\text {o. Nivel }}$ \\
\hline \multirow{5}{*}{ Nós de Origem } & Custo de Degradação nos Nós de Origem & Degradações ocorridas no Nó de Origem \\
\hline & \multirow{3}{*}{$\begin{array}{l}\text { Custo dos Terminais e } \\
\text { Plataformas de Origem }\end{array}$} & Sobreestadia \\
\hline & & Despesas e Tarifas Portuárias \\
\hline & & Custos de Terminais \\
\hline & $\begin{array}{l}\text { Custo Financeiro de Estoque nos Nós de } \\
\text { Origem }\end{array}$ & $\begin{array}{l}\text { Custo Financeiro de Estoque nos Nós de } \\
\text { Origem }\end{array}$ \\
\hline \multirow{12}{*}{$\begin{array}{l}\text { Movimentação } \\
\text { de Transferência }\end{array}$} & \multirow{3}{*}{$\begin{array}{l}\text { Transferência Marítima } \\
\text { Nacional }\end{array}$} & $\begin{array}{l}\text { Aluguel VCP/COA Entrega Marítima } \\
\text { Nacional }\end{array}$ \\
\hline & & Aluguel TCP Entrega Marítima Nacional \\
\hline & & $\begin{array}{l}\text { Custo Financeiro de Estoque em Navios } \\
\text { Nacional }\end{array}$ \\
\hline & \multirow{3}{*}{$\begin{array}{l}\text { Transferência Marítima } \\
\text { Longo Curso }\end{array}$} & $\begin{array}{l}\text { Aluguel VCP/COA Entrega Marítima } \\
\text { Longo Curso }\end{array}$ \\
\hline & & $\begin{array}{l}\text { Aluguel TCP Entrega Marítima Longo } \\
\text { Curso }\end{array}$ \\
\hline & & $\begin{array}{l}\text { Custo Financeiro de Estoque em Navios } \\
\text { Longo Curso }\end{array}$ \\
\hline & \multirow[t]{2}{*}{ Transferência Dutoviária } & $\begin{array}{l}\text { Tarifa de Transporte na Entrega } \\
\text { Dutoviária }\end{array}$ \\
\hline & & Custo Financeiro de Estoque nos dutos \\
\hline & \multirow{2}{*}{ Transferência Rodoviária } & $\begin{array}{l}\text { Tarifa de Transporte na Entrega } \\
\text { Rodoviária }\end{array}$ \\
\hline & & $\begin{array}{l}\text { Custo Financeiro de Estoque em } \\
\text { Caminhões }\end{array}$ \\
\hline & \multirow[t]{2}{*}{ Transferência Ferroviária } & $\begin{array}{l}\text { Tarifa de Transporte na Entrega } \\
\text { Ferroviária }\end{array}$ \\
\hline & & Custo Financeiro de Estoque em Trens \\
\hline
\end{tabular}

Tabela 11 - Classificação por nível nos Custos da Cadeia Integrada Fonte: A autora (2012). 


\begin{tabular}{|c|c|c|}
\hline $1^{0 .}$ Nível & $2^{0 .}$ Nível & $3^{0 .}$ Nível \\
\hline \multirow{5}{*}{$\begin{array}{l}\text { Nós } \\
\text { Intermediários }\end{array}$} & $\begin{array}{l}\text { Custo de Degradação nos Nós } \\
\text { Intermediários } \\
\end{array}$ & Degradações ocorridas nos Nós Intermedi \\
\hline & \multirow{3}{*}{$\begin{array}{l}\text { Custo dos Terminais e } \\
\text { Plataformas Intermediários }\end{array}$} & Sobreestadia \\
\hline & & Despesas e Tarifas Portuárias \\
\hline & & Custos de Terminais \\
\hline & $\begin{array}{l}\text { Custo Financeiro Estoque nos Nós } \\
\text { Intermediários }\end{array}$ & $\begin{array}{l}\text { Custo Financeiro de Estoque nos Nós } \\
\text { Intermediários }\end{array}$ \\
\hline \multirow{13}{*}{$\begin{array}{l}\text { Movimentação } \\
\text { de Entrega }\end{array}$} & \multirow{3}{*}{ Entrega Marítima Nacional } & $\begin{array}{l}\text { Aluguel VCP/COA Entrega Marítima } \\
\text { Nacional }\end{array}$ \\
\hline & & Aluguel TCP Entrega Marítima Nacional \\
\hline & & Bunker TCP Entrega Marítima Nacional \\
\hline & \multirow{3}{*}{ Entrega Marítima Longo Curso } & $\begin{array}{l}\text { Aluguel VCP/COA Entrega Marítima } \\
\text { Longo Curso }\end{array}$ \\
\hline & & $\begin{array}{l}\text { Aluguel TCP Entrega Marítima Longo } \\
\text { Curso }\end{array}$ \\
\hline & & $\begin{array}{l}\text { Custo Financeiro de Estoque em Navios } \\
\text { Longo Curso }\end{array}$ \\
\hline & \multirow[t]{2}{*}{ Entrega Dutoviária } & $\begin{array}{l}\text { Tarifa de Transporte na Entrega } \\
\text { Dutoviária }\end{array}$ \\
\hline & & Custo Financeiro de Estoque nos dutos \\
\hline & \multirow{2}{*}{ Entrega Rodoviária } & $\begin{array}{l}\text { Tarifa de Transporte na Entrega } \\
\text { Rodoviária }\end{array}$ \\
\hline & & $\begin{array}{l}\text { Custo Financeiro de Estoque em } \\
\text { Caminhões }\end{array}$ \\
\hline & \multirow[t]{2}{*}{ Transferência Ferroviária } & $\begin{array}{llll}\text { Tarifa de Transporte na Entrega } \\
\text { Ferroviária }\end{array}$ \\
\hline & & Custo Financeiro de Estoque em Trens \\
\hline & Remanejamento & Custo do Remanejamento de Produtos \\
\hline \multirow{5}{*}{ Nós de Destino } & Custo de Degradação nos Nós de Destino & Degradações ocorridas nos Nós de Destind \\
\hline & \multirow{3}{*}{$\begin{array}{l}\text { Custo dos Terminais e } \\
\text { Plataformas de Destino }\end{array}$} & Sobreestadia \\
\hline & & Despesas e Tarifas Portuárias \\
\hline & & Custos de Terminais \\
\hline & $\begin{array}{l}\text { Custo Financeiro de Estoque nos Nós de } \\
\text { Destino }\end{array}$ & $\begin{array}{l}\text { Custo Financeiro de Estoque nos Nós de } \\
\text { Destino }\end{array}$ \\
\hline
\end{tabular}

Tabela 12 - Classificação por nível nos Custos da Cadeia Integrada (continuação) Fonte: A autora (2012).

Os gráficos serão similares ao do custo arco a arco, assim como os detalhamentos, apresentado na Figura 22: 


\section{Custo Cadeia Integrada}

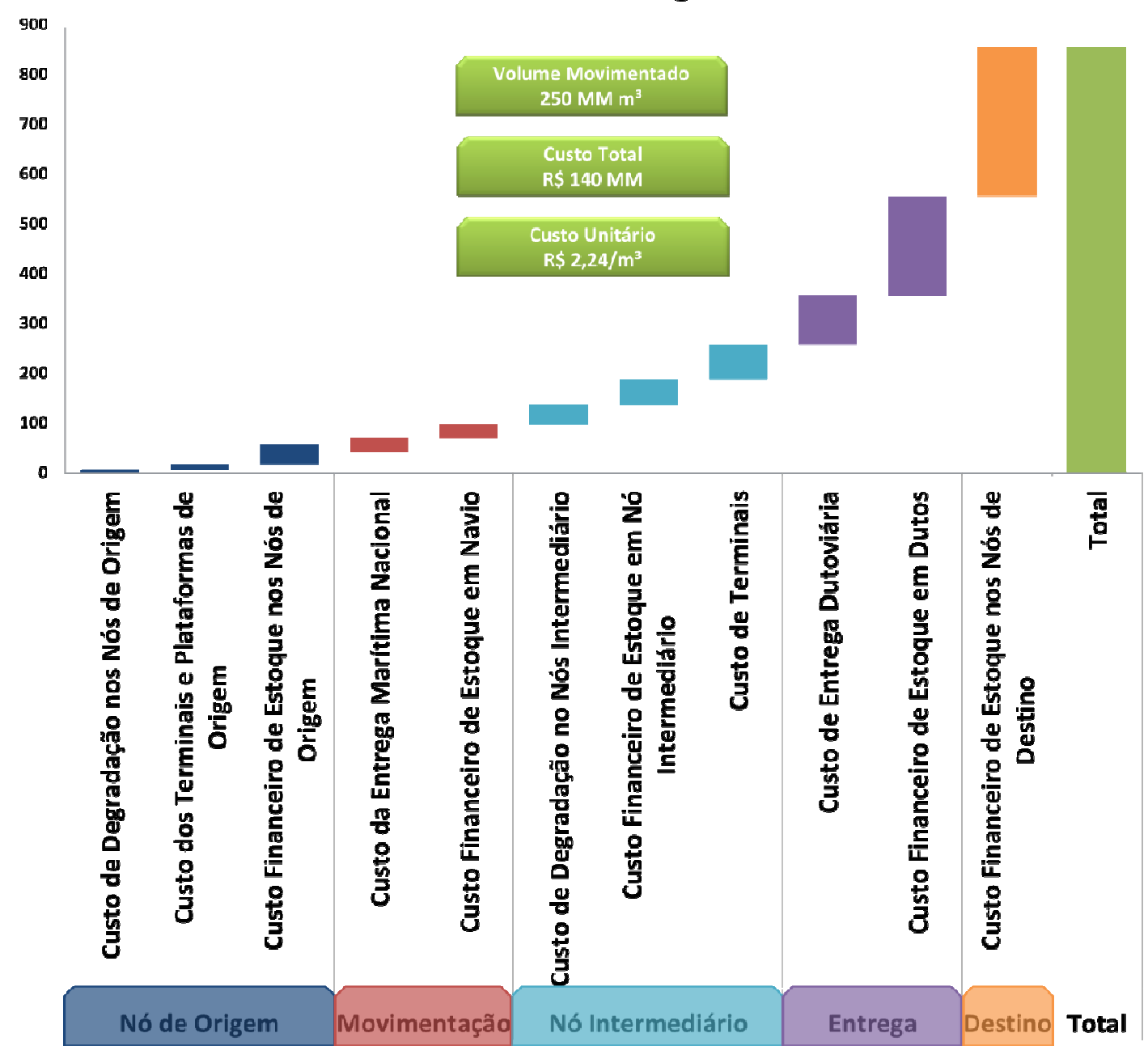

Figura 22 - Exemplo de exibição dos Buckets de custos da Cadeia Integrada Fonte: A autora (2012).

Da mesma forma que a visualização Arco a Arco, a ferramenta permitirá a escolha de um tipo de bucket (segundo nível do agrupamento) para o detalhamento e exibição dos elementos que o compõe (terceiro nível do agrupamento), exibindo para cada elemento o Valor Total, o Valor Unitário e percentual que ele contribui para o total do bucket. A Figura 23 mostra um exemplo de detalhamento. 


\section{Custo Cadeia Integrada}

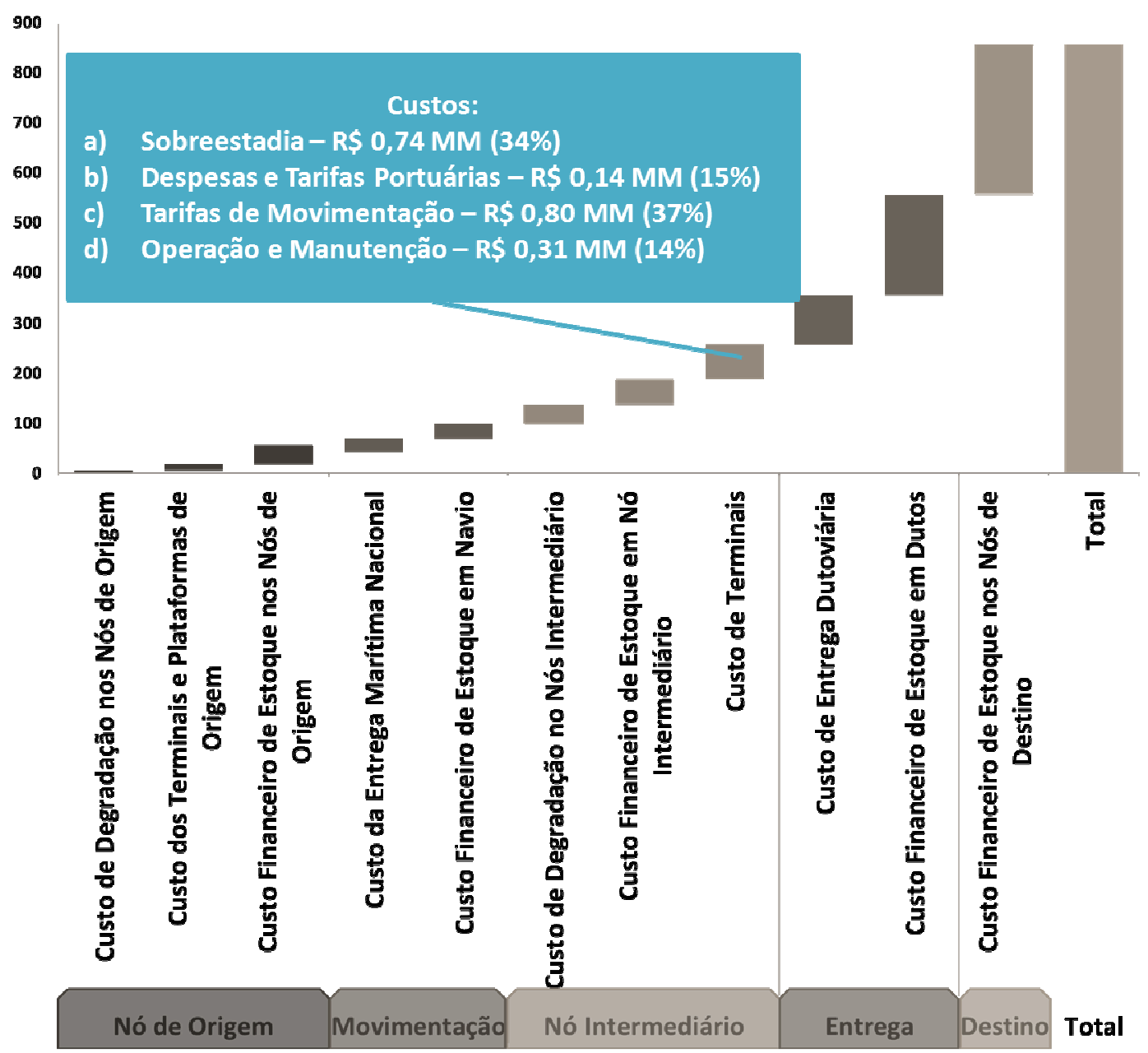

Figura 23 - Exemplo de Detalhamento dos Buckets para um determinado Bucket Fonte: A autora (2012).

A tela de análise da cadeia integrada deverá conter os mesmos filtros que na análise Arco a Arco. Filtros de período, produto, modal, origem e destino da entrega.

\section{5}

\section{Aplicando a Ferramenta de Análise}

Após todos os levantamentos apresentados e o desenho da ferramenta de análise elaborado, foi criado um protótipo para o cálculo dos resultados e visualização dos gráficos de análise conforme tal desenho.

Para essa construção foram identificadas as fontes de dados dos custos atribuídos às atividades da Logística de Abastecimento da Petrobras dentro do sistema contábil. Além disso, foram levantadas as informações operacionais as 
quais as atividades estão relacionadas como, por exemplo, estoques, volume transportado, distâncias percorridas, etc. Com isso, e seguindo as métricas apresentadas, os cálculos foram inseridos num banco de dados, onde os resultados obtidos, através da associação dos custos contábeis aos registros operacionais, seriam levados a uma planilha que proporcionaria a visualização dos resultados de forma gráfica.

Para viabilizar a implantação deste protótipo, foram as seguintes simplificações:

- Os custos de movimentação ferroviária e rodoviária foram desprezados neste primeiro momento do trabalho, visto que possuem pequena participação nos custos totais da área de Logística do Abastecimento (apresentado no Capítulo 3) e são informações de difícil associação entre os valores contábeis e as movimentações operacionais;

- Não foi realizada a estratificação dos custos dos terminais, onde o montante total representa custos de operação \& manutenção, movimentação interna, armazenagem e outros custos associados. A estratificação é uma etapa mais complexa e que requer maior detalhamento;

- Os custos do Refino, assim como os das Plataformas de Produção, não foram estratificados por estarem fora do âmbito da Logística de Abastecimento, contudo para se ter uma cadeia completa, estes custos se fazem necessários. Com isso, foi preciso realizar os cálculos e apresentação dos resultados em duas cadeias: a de derivados e de petróleo;

- Admitiu-se fluxo único de movimentação dos produtos, onde na prática é possível que um produto realize um fluxo inverso;

- Entre outras simplificações dos cálculos.

Foram realizadas algumas cargas de dados, contudo, apesar das simplificações feias, o protótipo ainda apresenta alguns erros nos cálculos e na apresentação dos resultados gráficos.

Uma dificuldade encontrada na implementação do modelo foi a existência de dados em diversos sistemas descentralizados da empresa. A forma de vincular 
os dados operacionais aos dados financeiros foi dificultada por não haver campos chaves nos documentos dos diversos sistemas.

Sendo assim, até o presente momento de apresentação deste trabalho, não foi possível avaliar os resultados da medição dos custos para servir e com isso propor melhorias nos processos avaliados.

Com isso, já foi dada início a uma pesquisa no mercado sobre a existência de ferramentas já estabelecidas e que possam atender aos requisitos levantados.

Até a data de encerramento deste trabalho foram encontradas duas ferramentas que se propõem a dar base para este modelo, são elas: Oracle Hyperion Profitability and Cost Management da empresa Oracle e SAP Profitability and Cost Management da empresa SAP. Foram realizadas demonstrações sobre a utilização das ferramentas, contudo ainda se faz necessário a realização de testes de conceito com mais detalhados para a conferir a realidade das atividades da Petrobras.

Concluiu-se nestas demonstrações que essas ferramentas são
ferramentas genéricas e podem ser utilizadas em qualquer tipo de
empresa/negócio/área de atuação. Então, elas requerem uma customização para
retratação do cadeia da empresa.




\section{6 Considerações Finais, Conclusão e Recomendações}

O presente trabalho apresentou como objetivo no Capítulo 1 a proposição da implementação de uma metodologia para medição dos Custos relacionados à área da Logística do Abastecimento de petróleo e derivados que possa dar suporte às tomadas de decisões estratégicas da Petrobras. Ainda se propôs a viabilizar conceitualmente a implementação desta metodologia, possibilitando o desenvolvimento de um sistema informatizado. Sendo assim, o objetivo foi atingido visto que os conceitos teóricos foram traduzidos para a realidade da empresa, as atividades foram mapeadas e os direcionadores de custo estabelecidos. Visto que no levantamento bibliográfico não foram encontrados trabalhos deste tipo na indústria de petróleo, este estudo tem uma grande importância acadêmica, contribuindo para a exemplificar que as teorias do método de Custeio ABC e Custo para Servir podem ser aplicados e possuem uma grande relevância para todos tipos de empresa no que diz respeito à Gestão de Custos.

O trabalho foi além do objetivo quando se elaborou um protótipo na tentativa de mensuração dos custos reais e análises de resultados. Este seria uma segunda etapa do trabalho, que fica como recomendação para estudos futuros baseados nos resultados que serão obtidos.

Ainda no que se refere a redomendações de estudos futuros, no caso da Perobras optar pela utilização de uma ferramenta existente no mercado e neste caso, sendo ela genérica, recomenda-se também que sejam estendidos os estudos para as áreas de Marketing \& Comercialização, Refino e Exploração \& Produção de petróleo, permitindo assim uma visualização da cadeia como um todo e o real Custo para Servir

Além disso, recomenda-se que as simplificações admitidas sejam estudadas com mais dealhes para que se possa retratar melhor a realidade dos custos da área de Logística do Abastecimento da Petrobras. Por exemplo, os fluxos de produtos podem ser reversos e para cada nó um produto pode entrar ou 
sair deste mesmo nó para um nó seguinte ou para um nó anterior. Além disso, a movimentação pode ser por mais de um modal de transporte. Então, na prática, trazendo um pouco mais de realidade para o modelo, recomenda-se que seja aplicado um algoritmo que deve percorrer a malha logística, consolidar os custos e acumulá-los da origem até a chegada do nó seguinte e assim por diante até chegar ao cliente final.

Outro ponto importante, para auxílio nas tomadas de decisão recomenda-se fortemente que esses custos levantados sejam associados a indicadores estratégicos, facilitando assim o estabelecimento da governança dos processos envolvidos. Deve-se considerar indicadores globais que possam ser desdobrados para facilitar a priorização de análise dos desvios de custo.

Algumas considerações no que dizem respeito ao levantamento bibliográfico sobre o Custo para Servir devem ser levadas em conta quando levase para aplicação. Foi possível identificar que na maioria dos casos estudados (na bibliografia) tiveram como foco principal a identificação da rentabilidade dos clientes. Nesses casos, a metodologia de mensuração do Custo para Servir foi aplicada com o intuito de verificar quais clientes eram rentáveis para empresa. No caso da área de Logística do Abastecimento da Petrobras, será aplicado o modelo pensando também em avaliar a rentabilidade dos canais de distribuição, assim como os pontos de vendas mais ou menos rentáveis. Outro objetivo que poderá ser atingido é a identificação de qual atividade dentro de uma entrega tem maior participação nos custos totais desta entrega, podendo estar indicando uma falha neste processo/atividade. Assim, permite-se trabalhar para a redução deste custo, caracterizando uma melhoria contínua dos processos.

Os benefícios da aplicação desta modelagem são inúmeros e com conceitos bem aplicados, a empresa poderá ganhar em varios aspectos, tanto de eficiência operacional como no que diz respeito a resultados financeiros. 


\section{Referências Bibliográficas}

ANDERSON, E.; KAPLAN, R. S. Time-driven activity-based costing. Harvard Business Review, Boston, v. 82, n. 11, p. 131-138, Nov. 2004.

BALlOU, R. H. Gerenciamento da cadeia de suprimentos/logística empresarial. 5. ed. Porto Alegre: Bookman, 2006.

BLOCHER, E. J.; CHEN, K. H.; COKINS, G.; LIN, T. W. Gestão estratégica de custos. São Paulo: McGraw Hill, 2007.

BOWERSOX, Donald J.; CLOSS, David J. Logística empresarial: o processo de integração da cadeia de suprimento. [S.1.: s.n.]: 2007.

BRAITHWAITE, A.; SAMAKH, E. The cost-to-serve method. The International Journal of Logistics Management, [S.1.], v. 9, no. 1, p.69-84, 1998.

BRASIL. Lei no 6.404, de 15 de dezembro de 1976. Dispõe sobre as Sociedades por Ações. Diário Oficial [da] República Federativa do Brasil, Brasília, DF, 17 dez. 1976. supl.

CHRISTOPHER, M. Logística e gerenciamento da cadeia de suprimentos. 2. ed. São Paulo: Thomson, 1997.

COUNCIL OF SUPPLY CHAIN MANAGEMENT PROFESSIONALS. [S.1.], [2012?]. Disponível em: <http://cscmp.org>. Acesso em: 02 jul. 2012.

DICIONÁRIO CAMBRIDGE. [S.1.], [2012?]. Disponível em: <http://dictionary.cambridge.org>. Acesso em: 02 jul. 2012.

FARIA, A. C.; BORINELLI, M. L.; MANTOVANI, N. Análises multidimensionais e o conceito do custo para servir. Revista de Contabilidade e Organizações, Sã Paulo, v. 4, n. 9, p. 126-144, maio/ago. 2010.

FARIA, A. C.; COSTA, M. F. Gameiro. Gestão dos custos logísticos. São Paulo: Atlas, 2005.

GOEBEL, D. Logística: otimização do transporte e estoques na empresa. Estudos em Comércio Exterior, [S.1.], v. 1, n. 1, jul./dez. 1996. 
GUERREIRO, R.; BIO, S. R.; MENDEL, S. F. Logística integrada, gestão da cadeia de suprimentos e mensuração de custos e resultados logísticos: um estudo com empresas brasileiras. Advances in Scientific and Applied Accounting, São Paulo, v. 4, n. 1, p.73-100, 2011.

GUERREIRO, R.; MERSCHMANN, E. V. V.; BIO, S. R. Mensuração do custo para servir e análise de rentabilidade de cliente: uma aplicação em indústria de alimentos no Brasil. Revista de Administração, São Paulo, 2008.

GUNASEFARAN, A.; PATEL, C.; TIRTIROGLU, E. Performance measure and metrics in a supply chain environment. International Journal of Operations \& Production Management, [S.1.], 2001.

HESKETT, J. L. Controlling customer logistics service. International Journal of Physical Distribution \& Logistics Management, [S.1.], v. 24, no. 4, 1994.

INNIS, D. E.; LALONDE, B. J. Customer service: the key to customer satisfaction, customer loyalty, and market share. Journal of Business Logistics, [S.1.], v. 15, no. 1, p. 1-27, 1994.

INTERNATIONAL ENERGY AGENCY. Key world energy statistics. [S.l.], 2011. Disponível em: <http://www.iea.org>. Acesso em: 02 jul. 2012.

JEFFERY, M. M., BUTLER, R. J., MALONE, L. C. Determining a cost-effective customer service level. Supply Chain Management: an International Journal, [S.l.], v. 13, n. 3, 2008.

JOHNSON, Allan, KAPLAN, Robert. Relevance lost: the rise and fall of management accounting. 2. ed. Cambridge: Havard Business School, 1991.

JOHNSON, E.; SIMONETTO, M.; MEEHAN, J.; SINGH, R. How profitable are your customers...really? Deloitte Review, [S.1.], 2009.

KAPLAN, R. S.; COOPER, R. Custo e desempenho: administre seus custos para ser mais competitivo. 2. ed. São Paulo: Futura, 2000.

KAPLAN, R. S. Kanthal (A) case. Harvard Business School, Boston, 1989.

KAPLAN, R.S., NARAYANAN, V.G. Measuring and managing customer profitability. Cos Management, Boston, v. 15, no. 5, p. 5-15. Sept./Oct. 2001.

LAMBERT, D. M.; BURDUROGLU, R. Measuring and selling the value of logistics. International Journal of Logistics Management, Ponte Vedra Beach, v. 11, n. 1, p. 1-17, 2000.

LAMBERT, D. M.; MENTZER, J. T. Is integrated physical distribution a reality? Journal of Business Logistics, [S.1.], v. 2, n. 1, p. 18-19, 1980.

LAMBERT, D. M.; STOCK, J. R.; VANTINE, J. G. Administração estratégica da logística. São Paulo: Vantine Consultoria, 1998. 
LAMBERT, D. M. The development of an inventory costing methodology: a study of the cost associated with holding inventory. Chicago: National Council of Physical Distribution management, 1976.

LAVALLE, C. O estágio de desenvolvimento da organização de empresas logísticas em empresas brasileiras: estudos de casos. 1995. Dissertação (Mestrado) - COPPEAD, Universidade Federal do Rio de Janeiro, Rio de Janeiro. 1995.

LIMA, M. Custos logísticos na economia brasileira. ILOS, Rio de Janeiro, 10 jan. $2006 . \quad$ Disponível em: <http://www.ilos.com.br/web/index.php?option=com_content\&task=view\&id=69 5\&Itemid=74\&lang=br $>$. Acesso em: 02 jul. 2012.

LOCKAMY III, A.; SMITH, W. I. Target costing for supply chain management: criteria and selection. Industrial Management and Data Systems, [S.1.], v. 100, n. 5, p. 210-218, 2000.

LUKKA, A. Evolution of logistics theory. In: ICL BEIJING CONFERENCE, 2004, Beijing. Proceedings... Beijing: [s.n.], 2004.

MARN, M. V.; ROEGNER, E. V.; ZAWADA, C. C. The power of pricing. The Mckinsey Quarterly, [S.1.], no. 1, 2003.

MASKEL, Brian $H$. Performance measurement for world class manufacturing: a model for American companies. Cambridge: Productivity, 1991.

MARTINS, E. Contabilidade de custo. 9. ed. São Paulo: Atlas. 2003.

MILONE, M.C. Análises de custos de servir e o impacto na relação entre indústria e varejo. In: SEMINÁRIO DE ADMINISTRAÇÃO - SEMEAD, 6., 2001, [S.1.]. Anais... [S.1.: s.n.], 2001.

MINISTÉRIO DE MINAS E ENERGIA. Balanço energético nacional 2011. Brasília, DF, 2011 Disponível em: <http://www.mme.gov.br/mme>. Acesso em: 02 jul. 2012.

MOREIRA, E. C. Gestão de custos logísticos baseada em atividades e no custo total de propriedade. [S.1.: s.n.], 2008.

NAKAGAWA, M. ABC: custeio baseado em atividades. 2. ed. São Paulo: Atlas, 2001.

NOREK, C. D.; POHLEN, B. J. Implementing activity-based costing (ABC) in logistics. Journal of Business Logistics, Oak Brook, v. 15, n. 2, p. 1-23, 1994.

NOREK, C. D.; POHLEN, B. J. Cost knowledge: a foundation for improving supply chain relationships. International Journal of LogisticsManagement, [S.1.], v. 12, n. 1, p. 37-51, 2001. 
PETROBRAS. Relatório Financeiro 2010. Rio de Janeiro, 2010. Disponível em <http://www.petrobras.com.br/pt/>. Acesso em: 02 jul. 2012.

PETROBRAS. Sistema de Gerenciamento de Resultados. Rio de Janeiro, 2012.

REEVE, J. M. Logistics and marketing costs: handbook of cost accounting: University of Tennessee. Knoxville: Prentice Hall, 1998.

SHARMAN, P. ABC and the bottom line on customers. CMA Magazine, [S.1.], p. 20-26, Sept. 1996.

SCOTT, DeCarlo. The world's biggest public companies. Forbes Magazine, [S.l.], Apr. $\quad 17 \quad 2013.20$ Disponível <http://www.forbes.com/sites/scottdecarlo/2013/04/17/the-worlds-biggestcompanies-2/>. Acesso em: 02 jul. 2012.

SMITH, G. E. Leveraging profitability in low-margin markets. Journal of Product \& Brand Management, [S.1.], 2006.

STERLING, J. U.; LAMBERT, D. M. Customer service research: past, present and future. International Journal of Physical Distribution \& Materials Management, [S.1.], v. 19, no. 2, 1989.

QUINN, K. Benefit-cost analysis of highway improvements in relation to freight transportation: microeconomic framework. [S.1.]: AECOM Team, 2001. Final report.

YERGIN, D. O petróleo. São Paulo: Scritta, 1994. 